\title{
Molecular Effects of FDA-Approved Multiple Sclerosis Drugs on Glial Cells and Neurons of the Central Nervous System
}

\author{
Kim M. A. De Kleijn ${ }^{1,2}$ and Gerard J. M. Martens ${ }^{1,2, *(D)}$ \\ 1 Department of Molecular Animal Physiology, Donders Institute for Brain, Cognition and Behaviour, \\ Centre for Neuroscience, Faculty of Science, Radboud University, 6525 AJ Nijmegen, The Netherlands; \\ k.dekleijn@science.ru.nl \\ 2 NeuroDrug Research Ltd., 6525 HP Nijmegen, The Netherlands \\ * Correspondence: g.martens@ncmls.ru.nl; Tel.: +31-243610564
}

Received: 14 May 2020; Accepted: 10 June 2020; Published: 13 June 2020

\begin{abstract}
Multiple sclerosis (MS) is characterized by peripheral and central inflammatory features, as well as demyelination and neurodegeneration. The available Food and Drug Administration (FDA)-approved drugs for MS have been designed to suppress the peripheral immune system. In addition, however, the effects of these drugs may be partially attributed to their influence on glial cells and neurons of the central nervous system (CNS). We here describe the molecular effects of the traditional and more recent FDA-approved MS drugs Fingolimod, Dimethyl Fumarate, Glatiramer Acetate, Interferon- $\beta$, Teriflunomide, Laquinimod, Natalizumab, Alemtuzumab and Ocrelizumab on microglia, astrocytes, neurons and oligodendrocytes. Furthermore, we point to a possible common molecular effect of these drugs, namely a key role for $\mathrm{NFKB}_{\mathrm{K}}$ signaling, causing a switch from pro-inflammatory microglia and astrocytes to anti-inflammatory phenotypes of these CNS cell types that recently emerged as central players in MS pathogenesis. This notion argues for the need to further explore the molecular mechanisms underlying MS drug action.
\end{abstract}

Keywords: fingolimod; dimethyl fumarate; teriflunomide; glatiramer acetate; interferon- $\beta$; microglia; astrocyte; neuron; oligodendrocyte; multiple sclerosis drug action

\section{Introduction}

Multiple sclerosis (MS) is an inflammatory disease of the central nervous system (CNS) characterized by oligodendrocyte pathology, microgliosis, astrogliosis, alterations of the blood-brain barrier (BBB), demyelination and neurodegeneration, and an exacerbating infiltration of both innate and adaptive immune cells into the brain [1,2]. MS is a complex disease with a large heterogeneity in MS lesions [3,4]. Furthermore, the non-lesioned white- and grey-matter regions in MS brains are different from those in healthy individuals [2,3]. For quite some time, the dysregulation of the peripheral immune system, causing immune cells infiltrating the CNS, autoreactivity against myelin sheath components and secondary BBB dysfunction, has been considered to be the primary cause of MS CNS pathology, defined as the outside-in hypothesis [5]. However, more recent research on MS and other neurodegenerative diseases has indicated a central role for a distinct type of macrophage found in the CNS, the microglia [6,7]. The hypothesis in which MS pathology is first and foremost caused by CNS-intrinsic factors, subsequently leading to the infiltration of peripheral immune cells via a leaking BBB, represents the inside-out model $[8,9]$, which is supported by pathological evidence showing the absence of peripheral immune cells in newly forming MS lesions [10].

Because the outside-in model has been the norm for a long time, the currently available MS drugs approved by the Food and Drug Administration (FDA) have been mainly designed to target 
various cell types within the peripheral immune system [11] and most drug-impact studies have been directed towards their peripheral effects on the cells of the adaptive immune system [12]. However, it is likely that the MS drugs also affect (innate) CNS cells and the molecular cascades associated with neuroinflammation, since most genes that are dysregulated in MS-peripheral immune cells are also expressed in microglia [13]. MS drug effects on CNS pathology have been mostly studied in humans and animals on the basis of the clinical features of disease progression, magnetic resonance imaging (MRI) measures, and blood or cerebrospinal fluid (CSF) levels of biomarkers for demyelination and neuronal degeneration [14-16]. For this reason, we set out to review studies assessing at the molecular level, the effects of MS drugs on the pathways operational in CNS cells.

Molecular effects on cell types in the CNS have been reviewed for a number of FDA-approved MS drugs, such as Fingolimod (FTY720; Gilenya), Dimethyl Fumarate (DMF; Tecfidera), Glatiramer Acetate (GA; Copaxone), Interferon-beta (IFN- $\beta$; Rebif, Avonex, Betaseron, Extavia, Plegridy) and Teriflunomide (TF; Aubagio) [17-28]. The CNS-directed molecular effects of more recently approved drugs, such as Laquinimod (LQ; Nerventra), Natalizumab (NZ; Tysabri), Alemtuzumab (AZ; Lemtrada) and Orcelizumab (OCR; Ocrevus), have been less well described, except for the neuroprotective effects of LQ and NZ [29-31]. In general, each of these previous studies has reported the (molecular) effects of only one or two MS drugs (e.g., [28,29,31]) on one or two CNS cell types (e.g., [22]). Moreover, the protective effects of MS drugs on neurons and oligodendrocytes have often been attributed to indirect effects caused by the actions of MS drugs on peripheral immune cells (e.g., [28]). Therefore, the effects of MS drugs have not been documented in multiple CNS cell types nor integrated into a common molecular cascade of events. The goal of the present review is to describe and compare the molecular effects of the traditional and recent FDA-approved MS drugs on multiple CNS cell types, focusing on microglia within the generally applied homeostatic (M0), pro-inflammatory (M1) and anti-inflammatory (M2) designation [32,33], and on astrocytes within the homeostatic (A0), reactive (A1) and neuroprotective (A2) nomenclature [34], as well as on neurons and oligodendrocytes.

\section{Molecular Effects of FDA-Approved MS Drugs on CNS Cells}

\subsection{Molecular Effects of FTY720}

The synthetic compound FTY720 is a structural analogue of the natural molecule sphingosine that modulates the Sphingosine 1-phosphate receptor (S1PR) in immune and brain cells [17-19,35-38], and is FDA approved as an oral therapeutic for relapsing-remitting MS (RRMS). Phosphorylated FTY720 (pFTY720) is able to agonize the S1PR, which causes the internalization of the receptor and functional antagonism [39]. The molecular effects of FTY720 on peripheral monocyte populations are reviewed elsewhere [12] and include the promotion of anti-inflammatory cytokine profiles of Band T-cells. Both the prominent S1P expression in neural cells [38], and its widespread effects on the proliferation, differentiation and the migration of neural cells [40] together with the fact that FTY720 is proven to be lipophilic and thus capable of crossing the BBB [41], make this drug an attractive treatment for diseases with neural pathology. The clear effect of FTY720 treatment on remyelination in the CNS has already been reviewed elsewhere $[22,23]$. In the next sections, we discuss the molecular effects of FTY720 specifically on microglia, astrocytes, neurons and oligodendrocytes (for details, see Supplementary Table S1; for article search terms, see Supplementary Information).

\subsubsection{Microglia}

Both in vitro and in vivo studies have shown that FTY720 has inhibitory effects on the pro-inflammatory (M1) microglia phenotype and stimulates the anti-inflammatory (M2) microglia phenotype [42-71]. In rodent models for several diseases, such as stroke, cuprizone-induced demyelination, MS (experimental autoimmune encephalitis, EAE), familial Alzheimer's disease (AD) and in irradiation-induced injury, FTY720 decreased microglia activation by polarization towards an anti-inflammatory M2 phenotype characterized by the increased expression of markers such as arginase 
1 (ARG1) and mannose receptor C-type 1 (MRC1/CD206) [42-44] and a decreased microglia M1 state, defined by the expression of allograft inflammatory factor 1 (IBA1), cluster of differentiation 68 (CD68) and lysosome-associated membrane protein 2 (LAMP-2; CD107b/MAC-3) [42,43,45-64,71] Consistent with these findings, in vitro FTY720 inhibited the expression of M1 microglia markers and promoted the M2 polarization of oxygen-glucose deprivation (OGD)-insulted microglia [55], photothrombotic stroke-derived primary microglia cultures [42] and white matter-derived microglia from an ischemia rat model [43] as well as in the microglia cell line N9 [63], and human and murine primary microglia cultures [65]. Moreover, FTY720 downregulated the mRNA expression of the pro-inflammatory cluster (e.g., C-C motif chemokine ligand (CCL)7, chemokine (C-X-C motif) ligand (CXCL)13 and CCL5) and upregulated genes in the anti-inflammatory cluster (e.g., granulocyte-macrophage colony-stimulating factor (GM-CSF), chitinase 3-like 3 (CHI3L3) and interleukin (IL)-10) in microglia cells from non-obese EAE mice [65]. Interestingly, this shift from M1 to M2 microglia phenotype was found to be modulated via the signal transducer and the activator of transcription (STAT) 3 activation in white-matter ischemia [43]. Thus, FTY720 converts a pro-inflammatory environment in the CNS into an anti-inflammatory milieu.

In lysolecithin-induced demyelination slice cultures, FTY720 enhanced remyelination through increases in IBA1-positive microglia via S1PR1/S1PR5 signaling, which could not be explained by an increased number of phagocytosing microglia [66] and the mechanism underlying this effect on microglia remains unclear. Others have reported no effect of FTY720 on IBA1-positive or MAC-3-positive cell numbers in the cuprizone-demyelination model [67-69] and in mice with facial nerve lesions [70].

In addition to affecting the phenotype, FTY720 modulated the secretion of pro-inflammatory factors and programmed cell death pathways in microglia [42-44,48,54,55,58,65,72-75]. In general, FTY720 treatment reduced the secretion of pro-inflammatory cytokines such as tumor necrosis factor alpha (TNF- $\alpha$ ), IL-1 $\beta$, IL-6 and CXCL5 in in vitro models such as lipopolysaccharide (LPS)- or 1-methyl-4-phenylpyridinium (MPP)-treated microglia cell lines and primary cultures $[43,44,55,58,72-74]$. A diminished presence of pro-inflammatory cytokines following FTY720 treatment was also found in in vivo rodent models for intracerebral hemorrhage (ICH) [47], cuprizone-induced demyelination [48], status epilepticus (SE) [54] and an 1-methyl-4-phenyl-1,2,3,6-tetrahydropyridine (MPTP)-induced model of Parkinson's disease (PD) [58]. In line with this, mRNA expression profiling in primary mouse microglia showed that FTY720 suppressed the expression of a wide array of LPS-induced inflammatory molecules such as IL- $1 \alpha$, IL-1 $\beta$ and CCL2 via a decrease in the expression of the transcription factors STAT1 and interferon regulatory factor (IRF)8 [74]. However, FTY720 did not affect the expression of the pro-inflammatory cytokines TNF $\alpha$, IL-1 $\beta$ and CCL2 in non-activated human and murine microglia cultures [65], and even increased the microglial secretion of the T-cell chemo-attractant IL-16 in a mouse traumatic brain injury (TBI) model [75]. In addition to pro-inflammatory cytokines, FTY720 reduced the expression and secretion of the oxidative stress factors inducible nitric oxide synthase (iNOS) and reactive oxygen species (ROS) in vitro and in vivo [42,55]. Taken together, these results show that FTY720 reduces the pro-inflammatory environment created by activated M1 microglia.

The production and secretion of pro-inflammatory factors is regulated via a number of molecular signaling cascades [76]. In LPS-stimulated mouse primary microglia, FTY720 reduced the signaling of the p38 mitogen-activated protein kinases (MAPK) stress pathway, but did not modulate c-Jun N-terminal kinase (JNK)1/2 activation [59] and reduced phosphoinositide 3-kinase (PI3K), protein kinase $\mathrm{B}(\mathrm{AKT})$ and glycogen synthase kinase 3 beta (GSK3 $\beta)$ phosphorylation in MPP-treated microglia [58]. Furthermore, FTY720 slightly reduced A $\beta 42$-induced pro-inflammatory cytokine production in LPS-induced Spinster homolog 2 (SPN2) knock-out and wild-type microglia [44] and inhibited the activation of nuclear factor binding near the kappa-light-chain gene in $\mathrm{B}$ cell (NFKB) $[44,55,58]$ and reduced the NLR family pyrin domain containing 3 (NLRP3) and caspase (CASP) 1 levels $[55,58]$. Surprisingly, FTY720 upregulated the expression of IL-1 $\beta$ and cleaved CASP1, and the oligomerization and dimerization of apoptosis-associated speck-like protein (ASC) in wild-type primary microglia, but not in ASC knock-out microglia [77], which implies again that FTY720 targets 
NFкB. Moreover in ischemia white matter-derived primary microglia cultures, FTY720 increased the levels of phosphorylated (p)STAT3 [43], which closely acts together with NFKB in inflammatory signaling cascades $[78,79]$. These results suggest that FTY720 targets signaling cascades involved in inflammation, such as NFKB and STAT3.

The additional activities of FTY720 are involved in the survival aspects of both microglia cells and other cell types via their interactions with microglia cells. The non-phosphorylated form of FTY720 stimulated the cleavage of CASP7 and CASP9, and induced apoptosis in the human microglial cell line HMO6 through the Sterol regulatory element-binding protein 2 (SREBP2) pro-apoptotic pathway, independent from S1PR binding [80]. This suggests that FTY720 also targets other pathways alongside S1P. In addition, FTY720 enhanced the expression of the growth factors brain-derived neurotrophic factor (BDNF) and glial cell line-derived neurotrophic factor (GDNF) in primary microglia [72], possibly showing its effect on neural trophic support via microglia. FTY720 treatment also increased the cell survival of neurons in co-culture with microglia on microfluidic chips and exposed to neurotoxic oligomers of amyloid-beta (A $\beta$ ) [81]. In support of a less inflammatory CNS environment, FTY720 also reduced the total brain $\mathrm{A} \beta$-levels in a mouse model of $\mathrm{AD}$ [45], possibly via microglia cells which play a major role in the internalization and degradation of $A \beta$ [82].

In summary, FTY720 targets the pro-inflammatory M1 phenotype, the downstream production and secretion of pro-inflammatory cytokines, and programmed cell-death pathways in microglia cells.

\subsubsection{Astrocytes}

In the astrocytes, but not in the neurons, of EAE mice lacking S1PR1, the neuroprotective effect of pFTY720 was diminished [82], showing its effect is mediated via the astrocytic S1PR1. In addition, cultured rat primary astrocytes represented the major cell type to respond to pFTY720, via the activation of Gi protein-mediated S1PR1 signaling cascades [83]. S1PR modulation is therefore a key target of FTY720 in the CNS and besides microglia, this compound acts on astrocytes.

FTY720 reduced the number of cells positive for reactive A1 astrocytic markers glial fibrillary acidic protein (GFAP) and S100 calcium-binding protein B (S100 $\beta$ ) in multiple rodent models, including in a model of familial AD [45,51], cuprizone-induced demyelination [48], MS [50,61,82], Huntington's disease (HD) [84], Status epilepticus (SE) [54], and models of infection [85], stroke [86], ICH [47], Pentylenetetrazol (PTZ)-induced kindling [56], and maternal inflammation [87] as well as wild-type rodents [88]. In contrast, FTY720-treated immortalized astrocytes displayed increased release of the astrocyte-secreted protein GM-CSF [89], whereas LPS-stimulated primary astrocytes decreased GM-CSF release following treatment with FTY720 [65]. No effect of FTY720 on astrocyte reactivity status has been found $[46,64,67-70]$ and even an increased number of GFAP-positive cells has been reported in in vivo models $[66,90]$.

In addition to a possible effect on the reactivity of astrocytes in vivo and in vitro, FTY720 modulates the production and secretion of pro- and anti-inflammatory cytokines by astrocytes. In non-obese diabetes EAE mice, FTY720 administration resulted in the decreased expression of reactive A1 astrocytic factors (including manganese-dependent superoxide dismutase (MnSOD), IL-6, CCL2, CXCL10, IL-1 $\beta$, TNF $\alpha$ ), and an upregulation of CXCL12 and IL-33 [65]. This effect of FTY720 on pro-inflammatory cytokines was confirmed in other rodent disease models [47,48,54,84,87,91]. Furthermore, the expression and secretion of pro-inflammatory cytokines in vitro was also reduced following treatment with FTY720 in both human and rodent primary cells from fetal and adult origin $[65,73,92-94]$ as well as in an astrocytoma cell line [95], while only one study has reported no effect of FTY720 on IL-1 $\beta$ and CCL2 [96]. The number of immediate-early astrocytes, characterized by FBJ murine osteosarcoma viral oncogene homolog (c-Fos)activation, was reduced following the treatment of the mouse EAE model with FTY720 [97]. It is currently not clear whether these c-Fos-positive astrocytes are neurotoxic (A1) or neuroprotective (A2), or how these cells contribute to MS pathology. Although the results of a minority of the studies are ambiguous, FTY720 generally decreased the reactive A1 astrocytic phenotype and the associated pro-inflammatory cytokine secretion. 
A number of studies has reported FTY720-mediated effects on cellular stress and inflammation pathways in astrocytes. In vitro, interferon-gamma (IFN- $\gamma$ )-stimulated rat astrocytes increased ADR- $\beta 2$ and reduced MHC-II expression following FTY720- and pFTY720 treatment through a decrease in NFKB p65 (also named RelA) [98]. In addition, FTY720 inhibited the degree of phosphorylation of NFKB and p65 both after cellular stress by OGD and in unstimulated primary astrocyte cultures $[65,90,92,93]$, and increased the inhibitor NFkB-alpha (Ikb $\alpha$ ) levels in a mouse HD model [84], both leading to a reduced NFKB activation. The observed effects of FTY720 on pro-inflammatory cytokine production in astrocytes can be explained by these effects on $N F \kappa B$, and are supported by its inhibitory effect on the production of the NFKB down-stream targets NLRP3 and IL-1 $\beta$, which was not present in S1PR1 knock-out astrocytes [99]. Cultured astrocytes treated with FTY720 upregulated leukemia inhibitory factor (LIF), heparin binding EGF-like growth factor (HBEGF) and IL-11 expression [95], molecules related to growth factors and MAPK signaling. Furthermore, in vitro and in vivo FTY720 affected the signaling pathways extracellular signal-regulated kinase (ERK) $1 / 2$ and MAPK, both known to regulate NFKB activation $[100,101]$. FTY720-treated cultured astrocytes also decreased expression of the reactive astrocyte protein high mobility group box 1 (HMGB1) and induced a blockade of Toll-like receptor (TLR)2 and PI3K signaling [93].

In addition to the activation, the cytokine secretion and the induction of inflammation pathways of astrocytes, other effects of FTY720 on astrocytes with a high relevance to neurodegenerative disease pathology have been reported. FTY720 reduced the mRNA and protein expression of the NFkB-related downstream immune factors intercellular adhesion molecule 1 (ICAM-1) and vascular cell adhesion protein 1 (VCAM-1) [57,94], and increased the mRNA expression of astrocyte-secreted vascular endothelial growth factor A (VEGF-A) [86], indicating its effect on the BBB. Furthermore, FTY720 reduced astrocyte migration and proliferation [98,102], and increased astrocyte survival after OGD in primary rat astrocyte cultures $[93,94]$. FTY720-treated primary cultures also displayed an elevated mRNA and protein expression of solute carrier family 1 member (SLC1A)3 and SLC1A4, showing the effect of FTY720 on glutamate metabolism, a process important for astrocyte-neuron communication [50]. The pre-treatment of cultured astrocytes with FTY720 before incubation with TNF $\alpha$ reduced the expression of two neuroinflammation markers, sphingomyelinase and ceramide [103]. The expression of oxidative-stress-related factors such as iNOS, Nitric Oxide (NO) and 3-Nitrotyrosine (3-NT) was also diminished by FTY720 in (LPS-stimulated) cultures $[65,92]$ and in mouse models of MS and HD [84,92], as well as FTY720-targeted cyclic adenosine monophosphate (cAMP) signaling and $\mathrm{Ca}^{2+}$-signaling in primary rat astrocyte cultures $[83,104]$. Thus, in addition to the attenuation of the neurotoxic A1 astrocytic phenotype, FTY720 exerts other positive effects on astrocyte functions.

\subsubsection{Neurons}

A number of effects of FTY720 on neurons has been described regarding protection against environmental stressors and general neuronal viability. In EAE and models of stroke, ischemia and epilepsy, FTY720 treatment resulted in the increased survival of neurons and axonal projections $[42,46,47,49,50,54,56,59,60,65,68,82,102]$. In vitro, FTY720 prevented neurodegeneration in $A \beta$-exposed rat neuronal cultures and microglia-neuron co-cultures on microfluidic chips [81], decreased apoptosis in neuroblastoma SH-SY5Y cells [58] and increased the survival of neuronal cells after glutamate or N-methyl-D-aspartate receptor (NDMA)-induced stress or in unstressed primary rodent neurons $[59,92,105]$. Therefore, neurodegenerative diseases with excitotoxicity as a central hallmark might benefit from FTY720 treatment. Moreover, FTY720 reduced the loss of tyrosine hydroxylase (TH)-positive dopaminergic neurons in a mouse PD model [58]. Additionally the presence of neurofilament-heavy chain (SMI32)-positive or amyloid precursor protein (APP)-positive axonal spheroids, indicating axonal damage, was profoundly reduced following FTY720 treatment in vivo and in rat primary cultures $[49,57,68]$. In contrast, neuronal loss was not attenuated by FTY720 after cuprizone-induced demyelination [69], white matter ischemia [43] and in demyelination related to Krabbe's disease [64]. In a rat model of myelin oligodendrocyte glycoprotein (MOG)-induced 
optic neuritis (MOG-ON), FTY720 reduced axonal damage, but did not prevent the apoptosis of retinal ganglion cells (RGCs) in the optic nerve [57]. Moreover, there was no effect on the number of non-phosphorylated SMI32- or APP-positive axons in FTY720-treated cuprizone mice [67,69]. Nonetheless, FTY720 attenuated dendritic spine loss and the expression of postsynaptic density protein 95 (PSD95) in a mouse model of HD [84], and reduced mossy fiber sprouting in SE rats [54]. At the structural level, the number and lengths of nodes of Ranvier increased due to the FTY720 treatment of white-matter ischemia mice [43]. Moreover, FTY720 normalized the physiological responses of neurons in EAE [56] and ameliorated neurotoxic increases in intra-neuronal Ca2+- in Ca2+-reporter mice [105]. These results indicate an effect of FTY720 on neuronal survival, and both structural and physiological changes that support neuronal transmission.

In line with these neuronal-positive effects, FTY720-treated rat neural stem cells (NSCs) differentiated into neurons and oligodendrocytes faster than non-FTY720-treated NSCs [106], and mouse primary neurons stimulated with the compound showed positive changes in growth cones and neurite outgrowth [70]. However, the addition of the supernatant of FTY720-treated cultures of primary rat astrocytes had no effect on neurite growth of the rat neuroendocrine pheochromocytoma cell line PC12 [50], which may indicate that FTY720 also acts directly on neurons. Furthermore, FTY720 increased the pool of neurons expressing the mature neuronal marker doublecortin (DCX) in mouse dorsal root ganglion (DRG) cultures [70], in mice with kainic acid-induced neurodegeneration [106] and in X-ray-exposed but not in wild-type mice [46]. Moreover, the expression of the neuronal differentiation marker beta-3-tubulin ( $\beta$ III-Tubulin) increased following the FTY720 treatment of rat-derived primary neurons [92], but the compound did not affect $\beta$ III-Tubulin and DCX expression in irradiated cultured cells [46], and did not promote the differentiation of human-induced pluripotent stem cells into neuronal nuclei (NeuN)-positive cells after transplantation into wild-type mice [88]. These results point to an effect of FTY720 on the proliferation and differentiation of neurons, possibly due to an increased phosphorylation of ERK 1/2, cAMP-response element binding protein (CREB) and p38 MAPK [107]. However, since FTY720 did not alter the number of calbindin-positive neurons in the cerebellum, Purkinje neurons appear not to be affected by FTY720 [64].

The cascade of intracellular events affected by FTY720 may include the increased neuronal expression of immediate early genes such as cFOS, FOSb and early growth response (EGR)1/2 [70]. Moreover, FTY720 directly affects the expression of S1P receptors, G12/13G-proteins, RhoA-GTPases, and the transcription factors serum response factor (SRF) and MKL/megakaryoblastic leukemia 1 (MRTF) in neurons [70,84], all being relevant modulators of neuronal differentiation and synaptic plasticity. Furthermore, specifically in the neuronal soma of the EAE CNS [61], and in the CNS of wild-type mice [70] FTY720 increased mRNA expression of BDNF, a growth factor promoting neuronal cell survival in addition to its functions in the neuro-immune-axis [108].

Thus, FTY720 exerts direct effects on neuronal excitotoxicity and neuronal differentiation, as well as an indirect effect on neuronal viability via other CNS cell types. Nonetheless, inconsistencies exist concerning the effect of FTY720 on axonal preservation, depending on the experimental model used.

\subsubsection{Oligodendrocytes}

Remyelination can be induced by FTY720 either via a direct effect on oligodendrocyte precursor cells (OPCs)/oligodendrocytes or indirectly by supporting other CNS cell types such as microglia and astrocytes, which provide metabolic and structural support to oligodendrocytes [109]. FTY720 reduced the extent of demyelination in the CNS of inflammation-induced and other demyelination rodent models $[50,56,57,60,65,82,88,107,110,111]$, in line with the increased axonal myelin sheaths formed in FTY720-treated human fetal OPC cultures [107]. However, FTY720 did not promote remyelination or reduce demyelination in the cuprizone-induced demyelination model $[67,69]$, which may be explained by the timing of the FTY720 administration. More specifically, to be effective in reducing demyelination and suppressing oligodendrocyte cell death, FTY720 should be applied within 10 days after initiating the cuprizone diet [48]. The fact that FTY720 caused myelin recovery following acute, but not 
chronic, cuprizone exposure [68], may also explain why FTY720 was not found to be effective in some cuprizone-diet studies. Overall, we conclude that FTY720 reduces the extent of demyelination, with the timing of disease induction and treatment being important for its efficacy.

Reduced demyelination may be attributed to a reduced degree of apoptosis of OPCs and oligodendrocytes [112,113]. Indeed, FTY720 reduced the oligodendrocyte apoptosis both in vivo [48] and in vitro $[43,107,114-116]$. In line with this, FTY720 increased the number of proliferating (bromodeoxyuridine/5-bromo-2'-deoxyuridin (BrdU)-expressing) OPCs in the brain [88,106,117], and the expression of the oligodendrocyte lineage marker oligodendrocyte transcription factor (OLIG2) in neural precursors derived from embryonic stem cells (ESCs) [115] and in the brains of Krabbe's disease mice [64], pointing towards an increased survival of oligodendrocytes. Additionally, in EAE rats and in a human oligodendroglioma cell line, FTY720 reduced ceramide levels [118], which are involved in oligodendrocyte metabolism and apoptosis.

The enhanced differentiation of OPCs towards myelin-producing cells may increase the remyelination of the CNS. In EAE mice, FTY720 increased the expression levels of the OPC proliferation and differentiation factors sonic hedgehog (SHH), smoothened (SMO) and SMO effector GLI family zinc finger 1 (GLI1) [117]. FTY720 treatment also promoted OPC differentiation in cultured human and rodent oligodendrocytes $[43,110,114,116,119]$ and in the CNS of a number of rodent demyelination models $[48,56,64,66,107,110,111,117]$, as shown by the increased mRNA and protein expression of the mature myelin markers myelin basic protein (MBP), proteolipid protein (PLP1) and $2^{\prime}, 3^{\prime}$-cyclic-nucleotide $3^{\prime}$-phosphodiesterase (CNPase). In contrast, FTY720 did not affect the protein expression of mature myelin markers in the cuprizone-induced demyelination model $[67,69]$. The reported FTY720-induced increase in OPC differentiation possibly resulted from phosphorylation events in the PI3K/AKT or ERK1/2 pathways $[107,110,114,116]$, albeit one study found that ERK 1/2 was phosphorylated in astrocytes, but not in oligodendrocytes, following treatment with FTY720 [120]. The downregulation of the growth factor BDNF in $\alpha$-synuclein $(\alpha \mathrm{SYN})$-treated OLN-93 oligodendroglial cells was counteracted by FTY720 [121], possibly pointing towards a critical role for this sphingosine analogue in oligodendrocyte-neuron communication. Finally, in a demyelination model of Krabbe's disease, the levels of myelin debris were not diminished by FTY720, while demyelination was reduced [64], suggesting that this compound targets the differentiation rather than apoptosis of OPCs in this disease model.

Taken together, treatment with FTY720 results in reduced demyelination alongside increased OPC survival and the promotion of OPC differentiation towards myelin-producing cells.

\subsection{Molecular Effects of DMF}

DMF belongs to the group of fumaric acid esters, and represents an FDA-approved treatment for MS and psoriasis [21]. Both DMF and its active metabolite monomethyl fumarate (MMF) exert anti-inflammatory and immune-modulatory effects in the peripheral system, as reviewed elsewhere [21]. DMF and MMF have both been described as activators of the transcription factor nuclear factor erythroid 2-related factor 2 (NRF2) in various neurodegenerative diseases, such as PD, MS and AD [24,25], and DMF also affects other oxidative stress-related pathways, including NFKB and hypoxia-induced factor $1 \alpha(\mathrm{HIF}-1 \alpha)$ [21]. Furthermore, MMF has a high affinity for the hydroxycarboxylic acid receptor 2 (HCAR2), which is not only expressed in monocyte-derived macrophages, but also in microglia and astrocytes [122]. In this section, we will discuss the specific molecular effects of DMF and MMF on CNS cell types (for details, see Supplementary Table S2; for article search terms, see Supplementary Information).

\subsubsection{Microglia}

Microglial M1 pro-inflammatory status, as measured by the number of IBA1- and CD68-positive cells, was reduced following DMF treatment in hypoperfused mice [123], in OGD-stressed rats [124], LPS-treated mice, vertebral hypoxic ischemia in mice [125], EAE mice [126], the mouse MPTP model 
of PD [127], rumpshaker hypomyelination mice [128], after spinal cord injury (SCI) in mice [129], ICH in mice [130] and in wild-type mice [131] as well as in mouse primary microglia cultures [132]. Interestingly, DMF increased the number of cluster of differentiation 86 (CD86)-positive microglia in aged rats with streptozotocin-induced AD [133], possibly due to altered inflammatory signaling in aged compared to non-aged microglia [7]. Levels of M2 microglia phenotype markers, such as MRC1/CD206, resistin-like alpha (RETNLA) and ARG1, were elevated by the addition of DMF to (activated) primary microglia cultures $[134,135]$. Similarly, treatment with the DMF-metabolite MMF decreased pro-inflammatory M1 marker expression [136] and increased anti-inflammatory M2 marker expression in vivo and in vitro [124,137], although one study did not confirm these findings [135]. No effect of MMF on the inflammatory state of microglia cells was found in cuprizone mice [138], and in human fetal and adult microglia cultures stimulated with LPS [122].

Moreover, DMF did not diminish the number of pro-inflammatory CXCR3-positive microglia cells in hippocampal slices stimulated with ATP [134]. In EAE animals, DMF alone did not show any significant effect on microglia, but interestingly, a combined treatment of DMF and IFN- $\beta$ resulted in a reduction of the number of inflammation-linked MAC-3-positive microglia [139]. Furthermore, microglial phagocytic activity increased following the DMF treatment of primary rat cultures [140] and MMF treatment of the cell line N9 [137], but was decreased in LPS-stimulated mouse microglia cultures [134]. Altogether, DMF and also MMF may induce a switch from a pro-inflammatory M1 to an anti-inflammatory M2 phenotype in a wide variety of CNS-related diseases, but it is not clear whether the resulting microglia become more phagocytic.

In accordance with a less-activated M1 microglia phenotype, the expression and secretion of pro-inflammatory mediators were reduced not only in DMF-treated primary rodent cultures [122,124,134,141-143] and BV-2 microglia cells [144,145], but also in DMF-treated OGD-stressed rats [124]. However, in mouse cortical explants, DMF had no effect on the expression of IL-1 $\beta$ [145]. The effect of MMF on pro-inflammatory mediators was ambiguous, since in LPS- and IFN- $\gamma$-stimulated primary human and rodent cultures, MMF did not affect IL- 6 and TNF $\alpha$ expression $[135,143,146]$, while expression levels of these factors were decreased in MMF-treated N9 cells [137] and isolated microglia cultures from glioblastoma multiforme tumors [136]. In MMF-treated co-cultures of HMC3 microglia cells and monocytes, the expression of CXCL10 by microglia was decreased [127]. Although not unequivocally demonstrated but at least in human and rodent microglia cells, DMF and MMF appear to reduce the pro-inflammatory microglia phenotype alongside a reduction in the secretion of pro-inflammatory mediators. This notion is also supported by a clear reduction in pro-inflammatory cytokine expression in the total brain tissue following the DMF treatment of rodents exposed to stroke, LPS-stimulation, spinal cord injury and MPTP-induction [125,127,129,132,140].

The effect of DMF on cytokine expression may be evoked by its inhibitory effect on NFkB p65 levels [132] and NFKB target-gene expression [143]. DMF indeed induced total brain expression

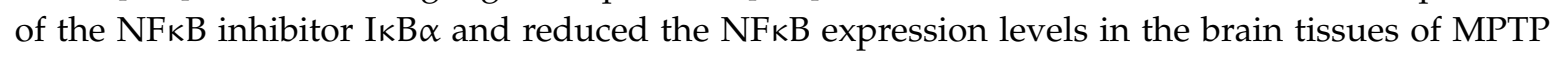
PD mice [127] and in a mouse model of SCI [129]. Moreover, in rat primary microglia, the DMF treatment resulted in decreased levels of pERK [142], an upstream regulator of NFKB. The microRNA 155 (miR-155) expression, which is transcriptionally regulated by NFkB, was also decreased by DMF in fetal and adult human microglia cultures [122]. The divergent effects of DMF and MMF described above may be explained by the fact that, in contrast to DMF, MMF causes not only an upregulation of NFKB target genes [143], but it also decreases NFKB p65 acetylation in microglia cells, resulting in a more inflammatory environment [137].

In microglia, DMF treatment may also affect antioxidant signaling, as the expression of oxidative stress factors such as NO and iNOS was diminished in DMF-treated rodent primary microglia [124,132,134,141-143], and the microglia cell lines BV-2 and N9 [137,145]. Furthermore, the expression of proteins important for the protection of cells against oxidative stress, such as Heme oxygenase 1 (HO-1), NAD(P)H dehydrogenase quinone (NQO-1) and glutathione (GSH), was elevated following the DMF treatment $[122,124,141,144,145]$. The results of these studies are supported by the 
attenuation of the oxidative milieu found in total brain tissue following the DMF treatment of wild-type mice [131], mice with ICH [140] and mouse models of cerebral hypoxic ischemia [125], PD [127] and SCI [129]. Moreover, DMF showed an inhibitory effect on LPS-stimulated NO bursts in cultured mouse microglia cells [138]. These results point to a role of DMF in the attenuation of oxidative stress in microglia cells. In addition, the DMF treatment of microglia in the culture resulted in decreased motility, a decreased response to ATP and increased ferritin uptake [134]. Moreover, supernatants from cultured DMF- and MMF-treated microglia cells enhanced OPC proliferation in vitro [135] and DMF reduced microglia toxicity towards neurons [132]. These findings indicate that the effects of DMF on microglia have also profound downstream influence on other CNS cell types.

\subsubsection{Astrocytes}

Multiple in vivo studies have reported that the application of DMF leads to a reduction in the number of reactive A1 astrocytes, based on decreases in the number of cells positive for the reactive astrocytic marker GFAP in wild-type mice [131], LPS-stressed C-X-C motif chemokine receptor (CXCR)1-GFP- labeled mice [132] and a mouse model of SCI [129]. In the mouse cerebral hypoxic ischemia model, DMF diminished GFAP-positive cells only after $6 \mathrm{~h}$ of treatment, but the number of reactive astrocytes increased after $24 \mathrm{~h}$ [125]. However, DMF had no effect on the reduced number of reactive A1 astrocytes in hypomyelinated rumpshaker mice [128] and the fumaric ester did not induce changes in TNF $\alpha$, IL- 6 and IL-1 $\beta$ expression in LPS- or IFN-y- and IL-1 $\beta$-stimulated rat primary astrocytes [147]. Nevertheless, DMF as well as its metabolite MMF, decreased the secretion of pro-inflammatory cytokines such as TNF $\alpha$, IL-1 $\beta$, CXCL10 and IL-6 from cultured LPSor IL-1 $\beta$-stimulated rodent and human primary astrocytes [142,148], and rat mixed glia and neuron cultures [124], respectively. Taken together, DMF and MMF affected the expression of pro-inflammatory cytokines in astrocytes and might have reduced A1 astrocyte numbers in a time-dependent manner.

The anti-oxidative capacity of DMF became apparent in a study on the co-cultures of microglia and astrocytes, in which the compound upregulated expression of the anti-oxidant factors NQO-1 and HO-1 [149]. Furthermore, DMF and MMF reduced intracellular ROS production, but had no effect on the mRNA expression of antioxidant-related genes in IL-1 $\beta$-stimulated human and mouse microglia cultures [148]. Interestingly, the $24 \mathrm{~h}$ treatment of rat primary astrocytes with DMF-reduced histone deacetylase (HDAC)1, HDAC2 and HDAC4 protein levels in the presence of cytokines, and the resulting nuclear NRF2:DNA binding activity was blocked by a selective inhibitor of the NRF2-target gene HO-1 [150], which again suggests a role for DMF in the modulation of oxidative stress.

A number of additional effects of DMF on astrocytes has been reported, e.g., in astrocytes from the mouse cerebral hypoxic ischemia model, and DMF reduced the levels of glutamine synthetase (GS) which is important for glutamine metabolism [125]. Moreover, following LPS stimulation or cytokine shock in primary rat astrocytes, the secretion of the growth factors nerve growth factor beta (NGF), GDNF, ciliary neurotrophic factor (CNTF), BDNF and fibroblast growth factor 2 (FGF2) was not modulated by DMF treatment [147], whereas GDNF, BDNF and neurotrophin-3 (NT3) expression was increased by DMF in astrocytes from SCI mice [129]. Other effects of DMF are the increased expression of the insulin-like growth factor (IGF-1) regulator placental alkaline phosphatase (PLAP) in the astrocytic cell line N18-RE-105 [151], and the decreased expression of miR-155 in human and mouse primary astrocyte cultures [147]. Finally, combined DMF-MMF treatment reduced the viability of glioblastoma tumor cells, which to some extent resembled the cells of the astrocytic lineage [136]. Thus, in addition to the downregulation of the pro-inflammatory environment and decrease in oxidative stress, DMF induced growth factors and metabolites important for astrocyte-neuron communication. The limited number of studies on the effect of MMF on oxidative stress precludes a firm conclusion.

\subsubsection{Neurons}

DMF decreased neuronal cell death in wild-type [131] and EAE mice [139], as well as in rodent models of AD [133], ICH [130] and cerebral hypoxic ischemia [125]. In addition, DMF reduced the 
neurodegeneration and the number of $\alpha$-Syn-positive neurons in an MPTP mouse model of PD [127]. The effect of DMF on neurodegeneration in the mouse cuprizone model remains unclear, as both a reduction [126] and no effect on the number of APP-positive axons [138] have been reported in this model. Moreover, in a mouse model of hypoperfusion, DMF did not diminish the number of APP-positive axonal spheroids [123], whereas in DMF-treated EAE mice, the number of preserved axons in inflamed lesions was doubled [139]. Treatment with the DMF-metabolite MMF reduced the toxic effect of HIV particle-stimulated microglia-monocyte co-cultures towards human fetal neurons [152]. Furthermore, MMF rescued cultured cortical neurons from OGD [124], and MMF and DMF increased the cell survival of primary human and mouse neuronal cultures stimulated with microglia medium $[132,146]$, alongside a reduction in cleaved CASP3-positive apoptotic neuronal cells [132]. Treatment with DMF also protected primary mouse cortical neurons against glutamateand NMDA-induced neurotoxicity [105], and neuroblastoma SH-SY5Y cells against MPTP-stress [127]. Finally, decreased neuronal damage was found in a brain biopsy of a DMF-treated MS patient when compared to the damage in treatment-naïve patient material [126]. Ex vivo monitoring of glutamate-mediated excitatory postsynaptic currents in mouse EAE-slice cultures showed that the effect of DMF on neurotoxicity was exerted via the modulation of glutamate release [137]. Taken together, these results confirm that both DMF and MMF play a role in inhibiting neurodegeneration, and as suggested by the results of three in vitro studies [132,146,152], DMF may achieve this through reducing microglial toxicity.

DMF also increased the levels of the antioxidants MnSOD-, HO-1- and GSH in MPTP-treated SH-SY5Y cells, and reduced the expression of cyclooxygenase 2 (COX2) and nNOS in a mouse model of PD [127]. In line with these results, HO-1 expression was increased in DMF-treated fetal microglia cultures stimulated with HIV-macrophage medium [152] and the compound decreased the expression levels of the oxidative stress marker 3-NT in a rat model of AD [133].

In addition, DMF may have an effect on dopaminergic neurons because it increased the number of TH-positive neurons as well as TH- and dopamine transporter (DAT) levels in a mouse PD model [127]. In line with these pro-neuronal findings, DMF diminished the phosphorylated Tau (pTau) protein levels in vivo [131] and reduced the mitochondrial respiratory deficits [143] and membrane potential disruption [132] in microglia-medium-treated rodent neuronal cultures. Moreover, the levels of the neuronal differentiation markers neurofilament (NF) and growth associated protein 43 (GAP-43) increased following DMF treatment in a mouse sciatic nerve model [153]. Finally, even though DMF did not affect axonal refractoriness in hypoperfused mice, the evoked compound action potentials (CAPs) improved after treatment [123] and DMF reduced the intracellular $\mathrm{Ca}^{2+}$-levels in transgenic mice carrying the calcium-sensing fluorescent protein TN-XXL [105], again supporting a protective role of DMF towards neurons.

\subsubsection{Oligodendrocytes}

DMF treatment of EAE mice increased Luxol fast blue (LFB) myelin-staining levels compared to non-DMF-treated animals [126,154] in a HCAR2-dependent manner [154]. Moreover, in the corpus callosum of a non-inflammatory, but toxin-induced mouse demyelination model, LFB myelin signals were raised by DMF treatment [138] and by the administration of DMF-containing lipoidal nanoparticles [155]. Interestingly, combined DMF- and IFN- $\beta$ treatment, but not DMF treatment alone, rescued myelination following EAE induction [139]. Thus, in rodent models of both MS and demyelination induced by a toxin, DMF affects myelination.

Furthermore, a higher number of mature oligodendrocytes was present in a brain-biopsy of a DMF-treated MS patient than in the treatment-naïve biopsies [126] and supernatants from DMF- as well as MMF-treated microglia cultures enhanced the proliferation of OPCs in vitro [135]. However, DMF did not increase the expression of myelin- and oligodendrocyte-related proteins and lipids nor myelin thickness (g-ratio) in hypoperfused mice [123], primary rat oligodendrocyte cultures treated with microglia medium [135] and the mouse rumpshaker hypomyelination model [128]. 
Nonetheless, DMF elevated the expression of the myelin-related proteins MBP, PLP, myelin-associated glycoprotein (MAG) and myelin oligodendrocyte glycoprotein (MOG) in cuprizone-fed mice [138] as well as the number of NPCs positive for the oligodendrocyte marker O4 [148]. The survival of the oligodendrocyte progenitor cell line CG4 was not increased by DMF treatment following stimulation with hydrogen peroxide $\left(\mathrm{H}_{2} \mathrm{O}_{2}\right)$ or a NO donor [138]. Thus, it is unclear whether DMF has a direct effect on oligodendrocyte lineage progression and overall oligodendrocyte survival. Nevertheless, the exposure of the oligodendrocyte cell line MO3.13 to DMF did result in changes in the levels of lipids, GSH and the intermediates of the citric acid cycle [156], indicating that to some extent the fumarate ester does affect oligodendrocyte metabolism.

\subsection{Molecular Effects of $G A$}

GA (also known as copolymer-1 or copaxone) is a mixture of synthetic polypeptides containing four naturally occurring amino acids (L-glutamic acid, L-alanine, L-tyrosine and L-lysine), approved for the treatment of RRMS and mainly known for its effect on T-cell differentiation [157]. Moreover, GA inhibits the activation of MBP-reactive T-cells and creates an anti-inflammatory T-cell environment by preventing the entry of these cells into the brain [158]. In addition, GA may only minimally protect the BBB [159], and exert an effect beyond the immunomodulation of cells of the innate and adaptive immune systems. For instance, GA protects neurons and oligodendrocytes and affects three processes characteristic of neurogenesis (neuronal progenitor cell proliferation, migration, and differentiation), as reviewed elsewhere [26-28]. Moreover, a limited number of studies has reported that GA might affect general AKT and MAPK signaling in the brain [160,161]. In addition, the neuroprotective effect of GA is still considered to be a side-effect of the suppression of immune cell populations [28]. The following sections focus on the direct molecular effects of GA on cells of the CNS (for details, see Supplementary Table S3; for article search terms, see Supplementary Information).

\subsubsection{Microglia}

Most studies report a reduction in the number of IBA1-positive and protein tyrosine-protein phosphatase (CD45)-positive activated microglia following the treatment of a rat cranial irradiation model with GA [162], the mouse EAE model $[160,161]$ and neuropathic allodynia rats [163], which points to a decrease in the number of pro-inflammatory M1 microglia. Moreover, the density of cells positive for the pro-inflammatory microglia markers integrin alpha-M precursor (MAC-1/ITGAM) and galectin-3 (MAC-2) was decreased in PLP- and MOG-induced EAE mice [164-166] and in a double-transgenic (APP/Presenilin-1; PS1) mouse AD model [167]. In addition, the morphological transformation of ramified resting microglia into a pro-inflammatory amoeboid morphology was attenuated in vitro by GA in human primary fetal and adult microglia activated by T-lymphocytes [168] and in EAE-mouse slice cultures [169]. In contrast, the number of IBA1-positive microglia increased in the hippocampus of a rat model of cranial irradiation-induced brain injury [162] and GA-treated cuprizone mice showed an expansion of MAC-1 and CD68-positive M1 microglia numbers [170]. Moreover, in primary cultures, the number of MAC-1-positive microglia was increased following the GA treatment [170]. Furthermore, GA treatment induced a phagocytic phenotype in cultured rat microglia cells [171] and increased the bacterial phagocytosis of IFN- $\gamma$-stimulated primary microglia [172], but not the phagocytosis of autologous human peripheral blood-derived mononuclear cells [173]. Moreover, GA caused a switch of microglia to an Integrin alpha-X precursor (CD11c/ITGAX)-positive dendritic-like phenotype in AD mice [167]. The exact effect of GA on the microglia M1 phenotype and its consequences may therefore depend on whether the model used is characterized by inflammation-dependent or inflammation-independent CNS pathology. Still, the previous studies suggest that GA might attenuate the M1 microglia phenotype and induce a switch towards phagocytosis rather than inflammation.

More consistent evidence towards a shift from a pro-inflammatory to an anti-inflammatory phenotype has been provided through studies analyzing the cytokines secreted by M1 pro-inflammatory microglia following treatment with GA. For example, a decrease in TNF $\alpha$ secretion was found 
after the GA treatment of BV-2 microglia cells [169], in IBA1-positive cells in EAE-mouse slice cultures [169], in primary rat microglia cultures [171], and in human fetal and adult microglia activated by T-lymphocytes [168]. In line with this, the migration of GA-exposed T-cells into the brains of EAE mice resulted in the increased expression of the anti-inflammatory microglial markers IL-10 and transforming growth factor-beta 2 (TGF- $\beta 2$ ) [174], but the GA-treated co-cultures of microglia and activated T-lymphocytes showed a reduction of IL-10 [168]. Furthermore, cultured GA-treated microglia showed increased IL-10 and IL-4 secretion [170,171], again supporting a possible switch from M1 to M2 microglia following GA treatment. Another contributor to a diminished pro-inflammatory environment is the reduction in the levels of the IL-17 protein, a strong inducer of inflammation, in GA-treated EAE mice [164]. In addition, TNF $\alpha$ and IL-6 levels are decreased in the total brain tissue of GA-treated irradiated rats [162] and EAE mice [175].

Thus, in addition to a change in microglia phenotype, GA shows effects on the expression and secretion of downstream inflammatory factors.

\subsubsection{Astrocytes}

The number of GFAP-positive cells in the CNS of EAE mice was reduced following GA treatment [176], although the polypeptide mixture did not affect GFAP-positive cell numbers in cranially irradiated rats [162]. Furthermore, infiltration of GA-induced Th2/3 cells into the brains of EAE mice caused increased expression of the anti-inflammatory factors IL- 10 and TGF- $\beta 2$ by astrocytes [174]. In addition, the bioactive BDNF expression was upregulated in astrocytes in GA-treated mouse HD models [177] and in primary mouse mesencephalic astrocyte cultures [177], which is in line with increased BDNF expression in CNS tissue of the rodent EAE, HD and irradiation models following GA treatment $[160-162,178]$. These results may point towards a GA-induced switch of reactive $\mathrm{A} 1$ astrocytes towards a neuroprotective A2 phenotype.

\subsubsection{Neurons}

GA reduced the number of APP-positive axons $[160,179,180]$ and SMI-32-positive cells $[180,181]$ and thus axonal damage in the CNS of EAE mice. Moreover, in a mouse model of organophosphate intoxication rescue of retinal neurons from cell death was reached by vaccination with GA [182] and neurodegeneration in mouse HD models was attenuated following GA treatment [177]. GA was even able to completely eliminate EAE pathology when the treatment was started at the same time as the induction of EAE in mice [183], which is in line with other studies, showing that GA administered at various stages of EAE induction led to a reduction of neuronal pathology and an increase in the number of BrdU/DCX-positive neurons [166]. In a cranial-irradiated rat model and a mouse AD model, GA also increased the number of BrdU/DCX-positive and BrdU/NeuN-positive neurons [162,176], confirming its positive effect on neuronal differentiation. Specifically, in the frontal cortex and hippocampus of EAE mice, the number of necroptotic receptor-interacting protein kinase 3 (RIP3)/NeuN-positive neurons decreased following the GA treatment [176]. In addition, 1H-magnetic resonance spectroscopy (MRS) of the MS brain showed that the $\mathrm{N}$-acetyl aspartate (NAA)/creatine $(\mathrm{Cr})$ ratio improved following GA treatment [184], indicating decreased neuronal damage, whereas no effect of such treatment on glutamate, NAA, Cr and phosphoCr ( $\mathrm{pCr}$ ) was found in the lesioned white matter of MS patients [185]. Still, GA increased the number of SMI32-positive neurons in EAE mice and the protein levels of the apoptosis marker cleaved CASP3 were reduced in primary mouse motor neurons treated with GA-astrocyte medium [177]. These results suggest that GA increases the survival of neurons and may display neuroprotective effects, possibly via its effect on astrocytes.

The therapeutic effect of GA on SMI32-positive neuronal cells was partially reversed after EAE induction in BDNF-knockout mice [181], suggesting that the neurotrophic factor was a crucial GA-target. This was confirmed since GA treatment increased BDNF expression in the DCX-positive cells of the mouse EAE model [166], as well as the total white matter of mouse lysolecithin-induced demyelination [186], cranially irradiated rats [162], EAE rodents [160,161] and transgenic mouse HD 
models [178]. However, in chronic EAE, no effect of GA on the total brain BDNF expression was found [187].

At the structural level, GA affected axonal conductivity, nodal organization [179] and axonal diameter $[179,187,188]$ in EAE mice. Furthermore, GA treatment reversed glutamate-mediated excitatory postsynaptic currents (EPSC) alterations [169] and the callosal action potential [179] in these mice. In line with this, the mRNA expression of synapse related-genes was induced in EAE mice [175]. The migration of neuronal cells to EAE lesion sites was also augmented by GA [166]. Finally, shortly after the EAE onset, the expression of neuronal-related genes was dysregulated in the spinal cord and normalized by GA treatment [175].

In sum, GA might have an overall effect on neuronal fitness via its effect on BDNF expression, and attenuate both structural and physiological axonal features.

\subsubsection{Oligodendrocytes}

Functional improvements in a number of CNS disease- and injury-based rodent models have been attributed to the reduced demyelination observed following treatment with GA, e.g., in EAE mice, GA increased the number of myelinated (MBP/NF-positive) axons as well as the thickness of the myelin sheath and the resulting g-ratio [188]. Furthermore, the mRNA expression of the oligodendrocyte genes MBP and OLIG2 dysregulated in the EAE spinal cords was normalized by GA [175]. Moreover, both in inflammatory and in non-inflammatory rodent demyelination models, the GA treatment resulted in reduced levels of demyelination $[160,161,165,180,186]$. However, when GA was applied to the mouse cuprizone model before inducing demyelination, the resulting myelin was still disorganized, whereas the administration during the demyelination phase generated better organized myelin and more mature oligodendrocytes [170]. In line with these findings, GA application during the MOG-immunization of the EAE model resulted in no brain pathology, and the treatment immediately after or one month after MOG-immunization caused less demyelination as well [183]. Thus, GA influences the extent to which demyelination occurs after various forms of injury induction, whereby the effect depends on the timing of GA treatment.

The GA-induced elevated number of myelinated axons may be explained by the fact that the immunomodulator increased the proliferation of OPCs in vivo $[170,179,183,188]$ as well as in embryonic forebrain and primary oligodendrocyte cultures stimulated with a medium from GA-treated T-cells [186,189]. Moreover, a conditioned medium from GA-treated microglia cells induced OPC differentiation [170]. Consistent with this, GA-stimulated oligodendrocyte differentiation was observed in EAE mice $[176,183,188]$, following GA treatment prior to or concomitant with cuprizone demyelination [170], and in GA-treated human T-cells co-cultured with primary human oligodendrocyte cultures [189]. Furthermore, GA treatment increased IGF-1 and BDNF protein levels in both the brain and spinal cord of EAE mice [188].

Taken together, GA enhances the proliferation and differentiation of OPCs both in vivo and in vitro, and furthermore may induce growth factor secretion that positively affects multiple CNS cell types.

\subsection{Molecular Effects of IFNs}

Interferons (IFNs) are naturally occurring cytokines, and their effects on the periphery as well as on the CNS are complex and not completely understood [190,191]. IFNs are known to have major effects on microglia cells, which may cause a cascade of consequences in other CNS cell types [192]. Remarkably, endogenous and exogenously administered IFNs may exert anti-inflammatory [193] as well as pro-inflammatory effects [194-197] in models for neurodegenerative and non-neurodegenerative diseases. The recombinant form of IFN- $\beta$ has been used as an FDA-approved treatment of MS. IFN- $\beta$ is a ligand for the Type 1 IFN receptor (IFNAR) [198], which prevents immune-cell infiltration of the brain by its stabilizing effect on the BBB, induces apoptosis of CD4+ and CD8+ Th17-cells, and stimulates the anti-inflammatory phenotype in B-cell populations in the blood [199]. The neuroprotective effects of 
IFN- $\beta$ on the CNS are thought to be indirect and all mediated via the attenuation of immune cell functions or blocking BBB leakage [28]. The neuroprotective effects of the not-FDA-approved interferon-alpha (IFN- $\alpha$ ) have not been previously reviewed. Since IFN- $\beta$ and IFN- $\alpha$ have different affinities for binding to the IFNAR1 and IFNAR2 receptors, with IFN- $\alpha$ being the low-affinity cytokine [200], and because the ratio of IFNAR1 to IFNAR2 surface expression determines the downstream signaling events in a given cell [201], the two interferons may differentially affect the CNS. We now describe the effects of a number of recombinant forms of IFN- $\beta$ on microglia, astrocytes, neurons and oligodendrocytes, namely that of the recombinant human (rh) IFN- $\beta$, produced in a mammalian cell expression system (IFN- $\beta-1 a$, also named Rebif or Avonex), rhIFN- $\beta$, produced in a bacterial expression system (IFN- $\beta-1 b$, Betaseron or Extavia) and IFN- $\beta$-1a, linked to polyethylene glycol (pegIFN- $\beta-1$ a or Plegridy), as well as the effects of IFN- $\alpha$ on CNS cell types (for details, see Supplementary Table S4; for article search terms, see Supplementary Information).

\subsubsection{Microglia}

The most-described effect of IFN- $\beta$ on microglia concerns its attenuation of the pro-inflammatory and activated M1 phenotype of these cells. For instance, IFN- $\beta-1$ reduced the overproduction of the pro-inflammatory factor and B-cell chemo-attractant CXCL13 in cultured microglia cells from IRF7-deficient mice [202]. In LPS-stimulated microglia cultures, the expression of the neuroinflammation and BBB adhesion factors, matrix metalloproteinase (MMP)-9 and MMP-2 [203] was reduced by IFN- $\beta$ and IFN- $\alpha$ [204]. In a mouse neovascular age-related macular degeneration (AMD) model [205], in germinal matrix hemorrhage (GMH) rats [206] and in a mouse model of MOG-induced optic neuritis [207], IFN- $\beta$ and IFN- $\alpha$ both attenuated the levels of IBA1- or CD68-positive M1 microglia, which indicates that in vivo IFNs have positive effects on microgliosis. In line with a reduction in microgliosis, IFN- $\beta$-1a reduced the total brain levels of the gliotic inflammation marker myo-inositol in RRMS patients, albeit to a lesser extent than Ocrelizumab (OCR), another MS drug described below [208].

In contrast, the intracerebroventricular injection of rIFN- $\beta$ increased the pro-inflammatory state of microglia cells and complement-dependent synapse elimination in the CNS of a mouse AD model, while blocking the type-I IFN receptor IFNAR1 diminished these effects [209]. The number of IBA1-, CD45- and CD68-positive microglia was also increased following the IFN- $\beta$ treatment of GBM8-fluc-implanted athymic nude mice [210] and in the offspring of IFN- $\beta$-treated mice [211]. In line with these results, the microglial surface expression of the inflammation-associated Fc receptor and major histocompatibility complex class II (MHC-II) proteins was increased following the in vitro administration of IFN- $\beta$ [212]. Moreover, IFN- $\beta$ increased both the activated morphology and the number of cells positive for M1 microglia markers in primary mouse microglia $[213,214]$. In addition to a more pro-inflammatory M1 phenotype, IFNs induced the expression and secretion of pro-inflammatory factors. The levels of CCL5 and CCL2, two major chemo-attractants of peripheral immune cells, were increased in MG6-1 microglia cells, cultured in the presence of IFN- $\beta$ and TNF $\alpha$ [215], and in IFN- $\beta$-treated primary mouse microglia cultures [202]. Moreover, IFN- $\beta$ and IFN- $\alpha$ enhanced the expression levels of TNF, IL-6, IL-1 $\beta$, IL-1 $\alpha$, CXCL10, CXCL9 and NO in (LPS-stimulated) primary rodent microglia cultures $[209,212,213,216-218]$ and microglia isolated after the maternal separation of the offspring of immune-activated dams [211]. Furthermore, the two interferons downregulated the levels of superoxide anions and glutamate [216], both related to neurotoxicity, and the IFN- $\beta$ treatment of the primary cultures of microglia stimulated with DNA or RNA upregulated the expression of the members of the Pyrin and HIN200 domain-containing proteins (PYHIN) family of DNA sensors [219], all again pointing to an IFN-mediated switch towards a more pro-inflammatory microglia milieu.

The induction of a pro-inflammatory M1 phenotype by IFNs may be explained by their effect on pro-apoptotic and pro-inflammatory signaling cascades. Nuclear STAT1 levels increased in IFN- $\beta$-treated AD mice [209] and the levels of pSTAT1 in microglia were induced by IFN- $\beta$ in the cell line MG6-1 [215], in mixed mouse glial cultures [209] and in primary mouse microglial 
cultures [213]. This is in line with the increased STAT1 levels in total brain tissue from the NADH dehydrogenase, subunit 4 (ND4) transgenic mouse demyelination model following the treatment with IFN- $\beta$ only, or IFN- $\beta$ combined with vitamin B12 [220]. Moreover in the total brain tissue from human rIFN- $\alpha$-treated GMH rats, the levels of pSTAT1 and phosphorylated Janus kinase 1 (pJAK1) increased, although the pNFkB-levels decreased [206]. Moreover, the mRNA expression levels of both STAT1 and STAT2 were induced in IFN- $\alpha$-treated primary mouse microglia cultures [217]. The phosphorylation levels of JAK1 and leukocyte receptor tyrosine kinase (TYK1), factors involved in the phosphorylation of STAT1, were elevated by the combined treatment with IL-1 $\beta$ and TNF $\alpha$ of MG6-1 cells [215]. In primary mouse microglia cultures, IFN- $\beta$ increased pNFkB-levels in IBA1-positive cells [213]. Furthermore, the expression levels of the NFKB interactors absent in melanoma 2 (AIM2), cyclic GMP-AMP synthase (cGAS) and interferon-inducible protein 204 (p204) were increased by IFN- $\beta$ in vitro [219]. Thus, IFN treatment results in the activation of pro-inflammatory microglia response pathways involving NFKB and STAT1/2.

In cultured microglia, more than in cultured astrocytes, IFN- $\alpha$ upregulated a wide set of genes related to pathogen detection and elimination, as well as a pro-inflammatory M1 phenotype $[217,218]$. Furthermore, the systemic administration of IFN- $\beta$ to dams of a mouse maternal immune activation model increased the stress sensitivity of fetal microglia [211], showing its profound effect on this cell type. Interestingly, neuronal and astrocyte IFNAR signaling, as well as the resulting secreted factors have been found to be important for the activation and proliferation of microglia [221].

Summarizing, while treatment with IFN- $\beta$ certainly affects microglia cells, its consequences are inconsistent and specific conditions, such as the type of model used, may influence its outcome.

\subsubsection{Astrocytes}

Like in microglia, a number of studies has shown that the administration of IFN- $\beta$ or IFN- $\alpha$ caused bimodal effects on astrocytes. In RRMS patients, IFN- $\beta$ reduced the levels of the gliotic inflammation marker myo-inositol, which is expressed by astrocytes and microglia [208]. Following the IFN- $\beta$ treatment, a reduced number of reactive A1 astrocytes was also found in the mouse EAE model [220,222], and these effects may be mediated by aryl hydrocarbon receptor (AhR) and suppressor of cytokine signaling 2 (SOCS2) signaling [222]. The increased proliferation of astrocytes in vitro induced by growth factors or cytokines was counteracted by IFN- $\beta$ treatment [223], indicating that this cytokine may reduce the astrogliosis response. Nonetheless, the administration of IFN- $\beta$ did not affect cell-cycle arrest in multiple glioma cell lines [224], but did reduce the pathogenic NO production in the astrocytoma cell line A172 [225]. Astrocytes are also important modulators of the endothelial cells that form the BBB. The fact that the application of IFN- $\beta$ reduced the expression of the BBB-adhesion molecule activators MMP-2 and MMP-9 in LPS-stimulated primary astrocytes in culture [204,226], as well as the permeability of endothelial-astrocyte co-cultures for polysaccharides, suggests that IFNs stabilize the BBB $[227,228]$. Moreover, IFN- $\beta$ inhibited the proteolytic MBP-cleavage activity of LPS-stimulated rat astrocytes [226], suggesting that the phagocytic activity of astrocytes may be modulated by IFNs. Importantly, in vitro the negative effects of LPS on the astrocyte proteome were reversed by IFN- $\beta$, mainly regarding cytoskeletal proteins and protein degradation, while the expression of protective enzymes such as MnSOD was increased [229]. Following IFN- $\alpha$ treatment, mouse primary astrocytes displayed an expression profile enriched for mRNAs encoding pathogen detection and elimination factors, which again may indicate a more reactive A1 phenotype, whereby the number of differentially expressed genes was lower than that found in microglia cells [217]. These studies suggest that IFN- $\beta$ reduces, whereas IFN- $\alpha$ may increase the neurotoxic A1 astrocytic phenotype.

In sharp contrast, IFN- $\beta$ treatment increased the number of GFAP-positive cells in the brains of wild-type mice [209] and in primary mouse astrocyte cultures [230]. In addition, in increased major histocompatibility complex class I (MHC-I), protein levels were found in IFN- $\beta$-treated NG97 astrocyte cells [231]. In addition, the protein levels and secretion of A1 astrocyte-related factors such as CXCL10, IL-6, CCL5 increased both in vitro [230] and in vivo [232] following the treatment with IFN- $\beta$ or the 
induction of IFN- $\beta$ via poly I:C administration. Moreover, IFN- $\alpha$ increased the levels of CCL2, IL- 6 and CXCL10 secreted by astrocytes in the co-cultures of human monocytes and astrocytes [233].

In addition to its effects on astrocyte reactivity, IFN- $\beta$ affects the survival of astrocytes, e.g., in stressed rat fetal astrocytes, the administration of IFN- $\beta$ itself increased apoptosis, but reduced TNF $\alpha$-induced apoptosis [234]. However, a decreased level of apoptosis of primary rat fetal astrocyte cultures or the lack of an effect of IFN- $\beta$ on cell survival in stressed primary rat neonatal astrocytes has also been reported [235]. These contradictory results may be explained by the fact that high doses of IFN- $\beta$ induced cell death in rat fetal astrocytes via decreased levels of p38 MAPK, while low doses increased the number of BrdU-positive and thus proliferating cells via an increase in pAKT levels $[236,237]$.

As in microglia cells, in astrocytes IFNs show an effect on the pro-inflammatory and apoptosis-related pathways STAT1/21 and NFKB. Both IFN- $\beta$ and IFN- $\alpha$ increased the STAT1/2 expression levels and the degree of phosphorylation of STAT1/2 in EAE mice [222] as well as in human fetal astrocytes [222], primary mouse astrocyte cultures [217] and mixed mouse glial cultures [209]. IFN- $\beta$ also increased the levels of nuclear p65 NFKB in the mouse EAE model [222], and high doses of this IFN induced cell death and decreased the protein levels of the NFKB-inhibitor I $\kappa B$ in serum-starved primary rat fetal astrocytes [236].

Taken together, IFNs may induce either a neurotoxic A1 or neuroprotective A2 astrocytic phenotype, depending on the specific disease-induced microenvironment.

\subsubsection{Neurons}

In the rat EAE model of MS, IFN- $\beta-1 b$ reduced clinical disease activity, but did not result in a protective effect on RGCs [160]. Similarly, MRS-measured levels of the neuronal integrity markers $\mathrm{NAA}, \mathrm{Cr}, \mathrm{pCr}$ and glutamate were also not modulated in the brains of RRMS patients treated with IFN- $\beta[185,238]$ even though the relapse rate was reduced [238]. However, increased NAA/Cr ratios, indicative of reduced neuronal injury, have also been found in the normal appearing white matter (NAWM) of MS patients treated with IFN- $\beta-1 b$ for 24 months $[239,240]$. Moreover, IFN- $\beta-1$ a caused a slight decrease in the loss of RGCs in a mouse MOG-induced optic neuritis model [207]. The exposure of neuroblastoma SH-SY5Y cells in culture to IFN- $\alpha 2$ enhanced $\mathrm{Cr}$, lactate and osmotic balances, and levels of metabolic waste products in the growth medium [241], which may have a positive effect on neuronal survival.

The literature is contradictory regarding the effect of IFNs on the protection of neurons from direct injury. In vitro, IFN- $\beta$ and IFN- $\alpha$ increased neuronal cell survival after the human herpesvirus 1 (HSV-1) infection of mouse neuronal cell cultures [242] or La Crosse Virus infection of human cerebral brain organoids [243]. Nonetheless, IFN- $\beta$ did not protect primary mouse neuronal cultures against viral infection [244] and IFN- $\beta-1$ a showed no neuroprotective effect on rat RGCs [207]. In addition, IFN- $\beta$ did not affect NDMA- or $\alpha$-amino-3-hydroxy-5-methyl-4-isoxazolepropionic acid receptor (AMPA)-induced cell death in mouse neuron-microglia co-cultures, but did attenuate the microglia-induced cell death of mouse neurons [216], suggesting that the effects of IFNs on neurons may be generated via microglia cells.

At a more physiological level, IFN- $\alpha$ reduced the firing rate of neurons via opiate receptors in the rat hypothalamus, normalizing their neuronal response [245]. Furthermore, levels of the synapse-associated protein synaptophysin (SYP) were reduced in PC12 cells, following the incubation with IFN- $\beta$ [246]. Supporting this notion, rIFN- $\beta$ reduced the levels of the synaptic protein PSD95 and the dendritic spine density in wild-type mice, via the induction of complement component 3 (C3)-dependent synapse elimination [209], again pointing towards the microglia-mediated effects of IFNs on neurons.

IFN- $\beta$ affected the phosphorylation levels of STAT1 [242], MAPK1/2 [207] and JAK1 [242] and total STAT1 protein levels [244] in primary rodent neuronal cultures. In addition, unlike normal neuronal cells, the exposure of STAT1-mutated neurons to IFN- $\beta$ did not render them resistant to 
HSV-1 infection [247], which indicates that this IFN indeed affects neuronal STAT1 signaling. Still, the low expression of STAT1 in neurons [244] might explain why IFN- $\beta$ does not have such profound effects on neurons compared to microglia and astrocytes.

\subsubsection{Oligodendrocytes}

In various inflammatory and non-inflammatory demyelination-induced rodent models, IFN- $\beta$ reduced demyelination in the brain and spinal cord, as was evident from the increased levels of myelin-related proteins $[207,220,248]$. Furthermore, the serum of untreated MS patients and of patients treated with IFN- $\beta$ for six months inhibited OPC proliferation in mixed rat glial cultures, while the serum of twelve-month IFN- $\beta$-treated patients did not show this effect [249]. Furthermore, in mixed rat glial cultures and primary OPCs, IFN- $\beta$ did not affect OPC differentiation or proliferation, but did not showed cytotoxic effects on the oligodendroglia cell line OLN-93 [250]. In primary rat oligodendrocytes, IFN- $\beta$ did attenuate neurogenic locus notch homolog protein 1 (NOTCH-1) and SHH signaling, which are main factors for OPC maturation [220]. Importantly, the inhibition of rat OPC differentiation by IFN- $\beta$ was only found in the presence of astrocytes and microglia cells [250]. As in neurons, this may again highlight the importance of astrocytes and microglia for IFN-induced effects on oligodendrocytes.

In EAE mice, IFN- $\beta$ significantly reduced multiple oxidative-stress parameters (malondialdehyde, peroxidation potential, ratio of catalase (CAT) to superoxide dismutase (SOD), and blood GSH), and also improved the redox state of the animals [251], which may indirectly result in an improved white-matter repair response since OPCs are very sensitive to oxidative stress [252]. Furthermore, IFN- $\beta$ did not show cytoprotective effects toward injury induced by $\mathrm{H}_{2} \mathrm{O}_{2}, \mathrm{NO}$, complement or glutamate [250]. These results indicate that the limited effect of IFN- $\beta$ on oligodendrocytes may occur via a reduction of oxidative stress and through its influence on other cell types such as astrocytes and microglia.

\subsection{Molecular Effects of TF}

TF is the active metabolite of its parent drug leflunomide and is FDA approved for the treatment of MS. TF inhibits the mitochondrial enzyme dihydro-orotate dehydrogenase (DHODH), blocking pyrimidine synthesis and leading to cell cycle interruption in T- and B-cells. Another peripheral effect of TF concerns the decrease in pro-inflammatory IL release from monocytes [253]. In the brain, TF reduced $B B B$ damage by increasing the number of pericytes, and the levels of the tight-junction proteins Zonula occludens protein-1 (ZO-1) and occludin (OCLN) [254]. Moreover, in the brain, TF targets circulating levels of pyrimidine and purine nucleotides, and of GSH and carbohydrate metabolism intermediates [255]. These molecules are linked to microglia activation, glutamate excitotoxicity and neuronal viability, which implies that TF may have an important impact on MS CNS pathology. Here, we review the specific effects of TF on microglia, neurons and oligodendrocytes (for details, see Supplementary Table S5; for article search terms, see Supplementary Information).

\subsubsection{Microglia}

A reduction in the number of pro-inflammatory M1 Sialoadhesin (SIGLEC-1)-positive or IBA1-positive microglia following TF treatment has been reported in rodent models for various diseases, such as in the brains of mice suffering from neuronal ceroid lipofuscinosis (CLN) [49], in the hippocampus of two different rat models for traumatic brain injury (TBI) [256], in the basal ganglia and the corpus callosum of a Theiler's murine encephalomyelitis virus (TMEV)-induced mouse demyelination model [257], and fewer IBA1-positive cells were also detected in the brains of transient middle cerebral artery occlusion (tMCAO) stroke mice [254]. At high concentrations, TF diminished the LPS- and IFN- $\gamma$ induced CD68 expression in vitro [258], and following LPS stimulation, the expression of the M2 microglia cytokine IL-10 was slightly increased in rat primary microglia and mixed glial cultures [258]. Furthermore, TF decreased the expression of the pro-inflammatory cytokines CXCL10, CCL2 and IL-6 in human microglia-monocyte co-cultures stimulated with HIV particles [146], and lower levels of the pro-inflammatory proteins IL-1 $\beta$, COX2 and 3-NT were detected following the 
TF treatment of mice with tMCAO-induced stroke [254]. However, in primary rat microglia cultures, no effect of TF was observed on the mRNA expression levels of iNOS, IL-6 and TNF $\alpha$ and on the

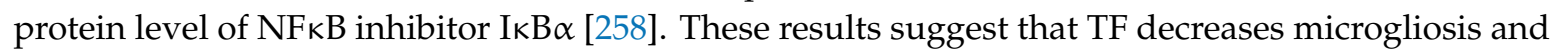
reduces the M1 pro-inflammatory microglia phenotype, although the molecular pathway involved is presently unclear.

\subsubsection{Astrocytes}

To our knowledge, there are at present no reports describing the effect of TF on astrocytes in culture or in in vivo models.

\subsubsection{Neurons}

The TF treatment of a mouse model of CLN resulted in a reduced number of damaged SMI32-positive axons, a reduced loss of RGCs and less thinning of the retina [49]. Axonal loss was also diminished by TF in the CNS of TMEV-demyelination mice [257]. In addition, TF treatment stimulated neurogenesis in the hippocampal sub granular zone of TBI rats [256], and upregulated the number of BrdU-/DCX-positive cells and the expression of mammalian achaete-schute homolog 1 (MASH1), DCX and PBX homeobox 1 (PBX1) in the sub ventricular zone of the mouse tMCAO stroke model [254]. In vitro, the neurotoxic effect of the medium from HIV-particle-stimulated microglia-monocytes co-cultures on human fetal neurons was attenuated by TF [146]. These studies indicated that TF may affect neurogenesis and neuronal survival.

\subsubsection{Oligodendrocytes}

In mice with TMEV-induced demyelination, TF did not increase the number of OLIG2- and CC1-positive oligodendrocyte lineage cells nor the myelin density when compared to the vehicle-treated animals [257]. In rat neuron-oligodendrocyte co-cultures, only low doses of TF led to cell-cycle exit, while high doses resulted in the reduced survival of oligodendrocytes [259]. The same study showed that only short-term pulses of TF promoted OPC differentiation towards CNPase-, MOG- and MBP-expressing cells in vitro [259]. These results indicate that the effects of TF on oligodendrocytes are modest and are possibly modulated by the concentration of TF or the duration of TF treatment.

\subsection{Molecular Effects of $L Q$}

LQ is an orally administered, synthetic derivative of linomide, that targets peripheral immune cells, such as activated IL-21-producing $\mathrm{CD} 4^{+} \mathrm{CD} 44^{+} \mathrm{T}$-cells, $\mathrm{C} 11 \mathrm{c}^{+} \mathrm{CD} 4^{+}$dendritic cells dendritic cells and B-cells [260], but it also displays neuroprotective effects in the mouse EAE model [30,31]. In addition, the linomide derivative might work via the AhR because LQ-treated mice showed major transcriptional changes of genes downstream of this receptor [261], such as the AhR hydroxylase Cytochrome P450 (CYP1A1). Here, we deal with the specific molecular effects of LQ on CNS cell types (for details, see Supplementary Table S6; for article search terms, see Supplementary Information).

\subsubsection{Microglia}

In rodent models, for both the acute and chronic type of EAE, as well as in rodent models in which non-immunological demyelination is induced in the CNS, optic nerve or retina, LQ reduced the density of IBA1-positive M1 microglia [261-265]. In EAE mice, mRNA and protein expression levels of IBA1, transmembrane protein 119 (TMEM119) and CD68 were also reduced by LQ [261]. Importantly, in AhR-knockout mice, no effect of LQ on the number of IBA1-positive cells was found [262], indicating that AhR is the main target of LQ. LQ also decreased the number of MAC-3- and CD45-positive microglia cells in cuprizone mice, EAE mice and mouse TLR4-knockout and myeloid differentiation primary response 88 (MyD88)-knockout demyelination models [261,265-269]. Moreover, LQ increased the protein level of the pro-inflammatory microglia marker translocator protein (TSPO) [267] in the 
CNS of cuprizone-exposed mice [265]. Nevertheless, an increase in TSPO in microglia cells is not necessarily associated with neurodegeneration [270]. The expression levels of factors that are associated with microglial inflammation, such as TNF $\alpha$, IL-1 $\beta$, IL-6 and MMP-9, were reduced in LQ-treated human and mouse microglia cultures [263]. However, LQ also reduced the levels of anti-inflammatory interleukins IL-10 and IL-4 in these microglia cultures [263], raising the question of which exact microglia phenotype it induces.

LQ further reduced the activity of c-Jun N-terminal kinase (JNK), ribosomal S6 kinase and AKT pathways in primary human LPS-stimulated microglia cultures, and lowered nitrite levels in mouse microglia-neuron co-cultures [263]. The microglia mRNA expression profile of an LQ-treated mouse model of TBI was similar to that of the sham (non-TBI) group, indicating that LQ reduces TBI-pathology [271]. However, in the mouse cuprizone model, LQ reduced pro-inflammatory factors via NFKB signaling only in astrocytes, but not in microglia cells [268]. Finally, LQ upregulated levels of microRNA 124a (miR-124a) [263], which targets a number of molecular pathways that preserves a microglia inflammatory state and was recently proposed as a potential biomarker for CNS diseases [272].

We concluded that LQ reduced the pro-inflammatory M1 phenotype of microglia cells in several CNS-located pathologies.

\subsubsection{Astrocytes}

Reactive gliosis, characterized among others by an increase in the number of GFAP- and vimentin (VIM)-positive cells, was reduced following the LQ treatment of cuprizone mice $[265,268]$ and in the EAE-induced mouse demyelination model $[261,262,266]$ with again no effect in AhR-knockout EAE mice [262]. One study has reported that LQ did not affect reactive astrocytes in EAE mice [269]. In vitro, LQ reduced the expression of the pro-inflammatory cytokines IL- 6 and CXCL10 in IL-1 $\beta$ - and IFN- $\gamma$-stimulated primary human astrocytes, but induced the protein expression of the chemokine CCL5 [273], a potential modulator of central glutamatergic transmission which is important for glial-neuron crosstalk [274]. Moreover, in IL-1 $\beta$-stimulated mouse astrocyte cultures, LQ increased the CCL5 mRNA and protein levels, and reduced the mRNA and protein levels of TNF $\alpha$, CXCL10 and IL-6 [268]. The expression of these pro-inflammatory cytokines was diminished by LQ via its inhibitory effect on NFKB activation in primary astrocyte cultures from TRL4-, MyD88- or Toll-like receptor adaptor molecule 1 (TRIF)-knockout demyelination mice [267] and cuprizone-fed mice [268]. Furthermore, LQ reduced both the NFKB levels and p65 nuclear translocation in IL-1 $\beta$-stimulated primary mouse astrocytes [268]. In sum, LQ attenuates the reactive A1 astrocytic phenotype and its pro-inflammatory downstream signaling events, possibly via NFKB signaling.

\subsubsection{Neurons}

Several neuronal parameters appear to be positively affected by LQ treatment. Multiple studies have shown that in rodents, LQ reduces the axonal injury inflicted by EAE $[262,263,266,269]$ and cuprizone [264,265,267,268], and after TBI [271] and neurodegeneration in the mouse R6/2 HD model [275] and genetically induced demyelination models [267]. Again, no effect was found on the number of APP-positive axons in LQ-treated AhR-knockout mice [262]. Moreover, when given prophylactically, LQ protected RGCs and reduced the apoptosis of neurons via the diminished cleavage of CASP3 in the mouse EAE model [261]. The effect of LQ on neuronal apoptosis may be explained by its reduction of BCL2-associated X (BAX) levels, which is a pro-apoptotic protein causing mitochondrial cytochrome-c release and caspase activation [276].

Not only was neuronal mortality reduced by LQ, but also the number of DCX-positive cells increased in the TBI mice [271], which suggests increased neurogenesis and maturation. This is in line with LQ-studies reporting increases in $\mathrm{NeuN}$-, protein phosphatase 1 regulatory subunit $1 \mathrm{~B}$ (DARPP-32)- and BDNF expression in neurons of the mouse R6/2 HD model [275] and in total brain tissue from wild-type mice [277]. Moreover, in human and mouse neuronal and microglia co-cultures, 
LQ increased the number of mature neuronal microtubule-associated protein 2 (MAP2)-positive cells [263]. Thus, LQ might affect neuronal injury via diminishing apoptotic signaling or increasing neuronal differentiation.

Furthermore, LQ alters the physiological response of neurons. In the mouse EAE model, both preventive and therapeutic LQ treatment changed $\gamma$-aminobutyric acid (GABA)ergic synaptic transmission, while only preventive LQ affected glutamatergic synaptic transmission as well, resulting in reduced glutamatergic excitotoxicity [269]. In line with this, LQ reduced the number of APP-positive axons, specifically of vesicular glutamate transporter 1 (VGLUT1)-positive glutamatergic neurons, and reduced the number of SYP-positive axonal spheroids in cuprizone-fed mice [265]. The neuronal output of the inner layer and b-wave amplitudes, as well as the callosal axon conduction and axonal refractoriness [266] also improved following the LQ treatment. In the co-cultures of mouse microglia and neurons, LQ decreased microglia-induced neurotoxicity [263] and the number of cells positive for iNOS in the mouse R6/2 HD model [275], indicating a positive effect on the degree of neurotoxicity and oxidative stress. However, in vitro, LQ had no effect on the expression of the chemo-attractants CXCL12 and CXCL88 in NSCs and it did not affect NSC differentiation after IL-1 $\beta$ stimulation [273]. Finally, and most relevant to HD pathology, LQ decreased the number of mutant-Huntingtin-positive PC12 cells, and diminished ATP production, proton leakage and basal respiration levels in the cell line [275]. The effects of LQ on neurons therefore include a reduction in axonal injury, an increase in neurogenesis, and an attenuation of GABAergic and glutamatergic synaptic transmission.

\subsubsection{Oligodendrocytes}

The clearly positive effects of LQ on the degree of demyelination, in models for various CNS-related pathologies, indicate that this synthetic drug improves myelination when applied as a prophylactic, as well as a therapeutic treatment in both mouse EAE and cuprizone models [261-265,268,269,278]. Moreover, in EAE mice, an increase in axonal conduction has been observed, in line with improved myelin integrity [266]. However, in one study, therapeutic LQ treatment did not affect optic nerve demyelination in EAE mice [261]. The effect of LQ on demyelination may be explained by the fact that in vivo, the linomide derivative reduced the apoptosis of oligodendrocytes [268]. Nonetheless, LQ did not affect the survival or mitochondrial respiration of primary mouse OPC cultures [268] or human ESC-derived OPCs stimulated with IL-1 $\beta$ [273]. Furthermore, based on the unaltered number of neural/glial antigen 2 (NG2)-, CNPase- and MBP-positive oligodendrocytes, LQ did not affect in vitro OPC differentiation [273]. In contrast, LQ did increase the number of oligodendrocytes positive for the cytoskeletal-related protein, the tubulin polymerization-promoting protein (P25) [267], which is in general highly upregulated in differentiating primary oligodendrocytes [279]. In EAE mice, MBP-, CC1 and PLP1-positive oligodendrocyte numbers increased after LQ treatment [266]. Finally, the treatment of oligodendrocytes with LQ had no effect on the expression of the chemo-attractants CXCL8 and platelet-derived growth factor subunit A (PDGF-A) [273]. Taken together, the treatment with LQ before as well as after the induction of demyelination appears to have a positive effect on the degree of myelination and myelin integrity, possibly via reducing oligodendrocyte apoptosis or via stimulating OPC differentiation.

\subsection{Molecular Effects of NZ}

$\mathrm{NZ}$ is a humanized monoclonal IgG4 antibody against the alpha-4 subunit of very late antigen-4 (VLA4) of $\alpha 4 \beta 1$ and $\alpha 4 \beta 7$ integrins [280] that are located on the plasma membrane of lymphocytes and monocytes. NZ is effective in RRMS patients and mainly prevents the infiltration of leukocytes into the MS brain [281], but also more specific effects on immune cells and hematopoietic populations in the CNS have been described [282]. Furthermore, NZ has important additional effects on the MS-affected CNS, including a reduction of oxidative stress and LPS-binding protein (LBP) levels [283], as wells as CSF levels of markers for intrathecal inflammation, axonal damage and demyelination [29]. In the following 
paragraphs, we discuss the effects of NZ on microglia, astrocytes, neurons and oligodendrocytes (for details, see Supplementary Table S7; for article search terms, see Supplementary Information).

\subsubsection{Microglia}

Overall, most studies point to an effect of NZ on the attenuation of microgliosis by reducing the activated M1 microglia response in various disease models, such as in the APP1/PS1 mouse model of AD [284] and in EAE mice [285]. The NZ treatment of MS patients also reduced the pro-inflammatory microglia phenotype, as established by PET scanning, using the pro-inflammatory microglia marker 11C-PK11195, which binds to the mitochondrial outer-membrane translocator protein TSPO [286,287]. Moreover, CSF levels of soluble triggering receptor expressed on myeloid cells 2 (sTREM-2) [288] and the chitotriosidase (CHIT1) [289], markers for pro-inflammatory microglia [290,291], were decreased following NZ-therapy in MS patients. Thus, NZ has an effect not only on peripheral, but also on brain-resident immune cells, possibly because microglia express the NZ-antigen integrin VLA-4 when phagocytosing neuronal debris [292].

\subsubsection{Astrocytes}

Astrogliosis was reduced in a mouse AD model treated with NZ, when compared to untreated animals and based on the number of reactive A1 GFAP-positive astrocytes and the protein expression level of GFAP [284]. Moreover, following the NZ treatment of EAE mice, the protein levels of the inflammation-associated protein lipocalin 2 (LCN2) $[293,294]$ was reduced in inflammation-activated GFAP-positive astrocytes [295]. The CSF and the CNS of both EAE mice and MS patients also contained elevated LCN2 levels, which were modulated by NZ treatment [295]. Interestingly, the reactive astrocyte-confined expression of CXCL12 was downregulated in NZ-treated EAE mice [282], suggesting that in addition to reducing the reactive astrocytic phenotype, the drug also affects downstream chemokine signaling.

\subsubsection{Neurons}

In the mouse EAE model, NZ treatment resulted in more NF-positive cells, indicating reduced axonal damage [285]. Interestingly, NZ normalized the synaptic changes found in the mouse APP/PS1 model of AD by increasing the PSD-95 levels [284]. Moreover, RRMS patients treated with NZ showed an increase in the concentrations of NAA, $\mathrm{Cr}, \mathrm{pCr}$ and glutamate in lesioned white matter [185]. These findings point to an effect of $\mathrm{NZ}$ on axonal and mitochondrial metabolism.

\subsubsection{Oligodendrocytes}

$\mathrm{NZ}$ reduced the inflammation-mediated demyelination in EAE mice, as indicated by the increases in the number of MBP-positive cells [285]. In line with this, LCN2, which in vivo is decreased by NZ, inhibits remyelination in rat neuron-oligodendrocyte co-cultures [296]. Possibly, NZ affects remyelination by oligodendrocytes, but more studies are needed.

\subsection{Molecular Effects of $A Z$}

AZ is a humanized monoclonal antibody against the 12-amino acid cell-surface glycopeptide cluster of differentiation 52 (CD52), which is an antigen found on the surface of B- and T-lymphocytes [297], but not on the surface of hematopoietic stem cells. The extent to which certain immune cell subpopulations are affected by AZ differs due to the variable surface-expression levels of CD52 [298]. The function of CD52 is largely unknown, but this glycosylphosphatidylinositol (GPI)-anchored glycopeptide is thought to contribute to the activation and migration of T-cells, and the induction of regulatory T-cells [299]. Moreover, CD52 was recently found to be expressed on the surface of microglia cells under neuropathological conditions in the mouse [300]. We now discuss the effects 
of AZ on CNS cell types (for details, see Supplementary Table S8; for article search terms, see Supplementary Information).

Microglia, Astrocytes, Neurons and Oligodendrocytes

The number of studies on the effects of AZ on CNS cells is limited. In hippocampal slice cultures of EAE mice, the blockade of CD52 with anti-mouse CD52 antibody triggered microglia morphology towards a less ramified, and thus possibly more activated M1 phenotype [301], while this antibody did not affect neuronal $\mathrm{Ca}^{2+}$ levels or neuroprotection against excitotoxicity [301]. To our knowledge, there are at present no reports describing the effect of $\mathrm{AZ}$ on astrocytes and oligodendrocytes, in culture or in in vivo animal models. AZ may have beneficial effects on CNS-resident glial populations, since CD52 expression is mainly found on microglia, and to a lesser extent on astrocytes, and is upregulated following the in vitro LPS treatment of primary mouse microglia cells [301].

\subsection{Molecular Effects of OCR}

OCR is a humanized monoclonal IgG1 antibody against an extracellular domain of the glycosylated protein cluster of differentiation 20 (CD20), that is expressed on pre-B-cells, mature B-cells and memory B-cells [302]. OCR is the most recently approved treatment for both RRMS and primary-progressive MS (PPMS). The main function of OCR is the elimination of B-cells from peripheral blood, primarily through antibody-dependent cellular cytotoxicity (ADCC) and to a lesser extent by antibody-dependent cellular phagocytosis (ADCP), complement-dependent cytotoxicity (CDC) and the direct apoptosis of B-cells $[303,304]$. In the next paragraph, we review the effects of OCR on CNS cell types (for details, see Supplementary Table S9; for article search terms, see Supplementary Information).

\section{Microglia, Astrocytes, Neurons and Oligodendrocytes}

The effects of OCR have been studied only in astrocytes and neurons. OCR displayed a superior effect, relative to IFN- $\beta$, with respect to reducing gliosis in the mouse EAE model as well as in MS patients [208]. In a recent MRS study on RRMS patients, OCR was found to reduce gliosis, as shown by a reduction in the gliotic inflammation marker myo-inositol, and stabilized the total choline and total $\mathrm{Cr}$ levels in the brain, indicating a decreased neurotoxic and inflammatory environment [208]. Moreover, in two rat MS models, anti-CD20 therapy reduced the number of MHC-II-positive microglia and decreased the binding of the TSPO-radioligand $\left({ }^{125} \mathrm{I}\right) \mathrm{DPA}-713$, indicating decreased microgliosis [71]. However, anti-CD20 treatment did not result in decreased numbers of MAC3-positive microglia nor in reduced demyelination in an MS mouse model [305]. To our knowledge, there are at present no other reports describing the effect of OCR on cells in culture or in in vivo animal models, possibly since this antibody is one of the most recent MS drugs to have become FDA approved.

\section{Discussion}

In the previous sections, the effects of various FDA-approved drugs for MS on microglia, astrocytes, neurons and oligodendrocytes were described on the basis of results from studies on cells in culture, in animal models and in humans. Of note, any discrepancies in the extent of the effects reported in the various studies may be attributed to differences in the cell lines or species used, the methods of drug administration and/or the concentrations of the drugs applied. Most evident were the actions of the drugs regarding the modulation of the pro-inflammatory downstream cascades within microglia and astrocytes, and we therefore discuss in particular their effects on these CNS cell types. Since microglia and astrocytes are involved in maintaining the neuronal network [306] and the quality of myelin [307], we also deliberate on how their drug-induced changes may affect neurons and oligodendrocytes. Finally, we consider how microglia and astrocytes may influence the inflammatory state of each other. 


\subsection{FDA-Approved MS Drugs Induce the Transition from a Pro-Inflammatory into an Anti-Inflammatory} Microglia Phenotype

FTY720, the synthetic analogue of sphingosine, reduced in vitro and in vivo the secretion of pro-inflammatory cytokines and the expression of pro-inflammatory factors in microglia. However, in the mouse cuprizone-demyelination model, FTY720 did not in all investigations switch microglia to an anti-inflammatory phenotype. The fumaric acid ester DMF, and the active leflunomide metabolite $\mathrm{TF}$, also reduced the number of activated M1 microglia in in vivo models of inflammation or otherwise induced CNS pathology. The DMF studies that showed a reduction in the expression and secretion of pro-inflammatory factors were mainly performed in vitro, while the TF studies were both in cell cultures and in rodent models. Treatment with the synthetic polypeptide mixture GA caused not only a reduction in pro-inflammatory cytokine expression and secretion, both in vitro and in vivo, but also an increase in neuroprotective cytokine expression and a reduction in the number of microglia with a pro-inflammatory M1 phenotype. In addition, GA may stimulate phagocytosis by microglia cells. For unknown reasons, the naturally occurring cytokines IFN- $\beta$ and IFN- $\alpha$ caused in (un)stressed cell cultures, as well as in wild-type rodents and rodent CNS-related disease models, the conversion of microglia cells into either a pro-inflammatory M1 or an anti-inflammatory M2 phenotype. However, the IFN- $\beta$ studies performed in vitro point more to an induction of the expression of pro-inflammatory cytokines and other factors. The synthetic linomide derivative LQ as well as the humanized monoclonal antibody NZ reduced the number of pro-inflammatory microglia cells in animal studies and in MS patients. Unfortunately, no studies, or only a very limited number of studies, on the humanized monoclonal antibodies AZ and OCR have been reported with respect to their impact on microglia.

Altogether, the in vitro and in vivo findings indicate that, except for IFN- $\beta$, the various FDA-approved MS drugs described here have a clear effect on the transition from a pro-inflammatory into an anti-inflammatory microglia phenotype (Figure 1A). This effect is particularly evident in inflammatory (EAE) as well as non-inflammatory (Cuprizone, Lysolecithin, TBI, AD) rodent models in which neurotoxicity and demyelination are central factors causing pathology. In general, the results of the in vitro studies are in line with this inference. We argue though that more studies should be performed, especially on AZ and OCR.

A

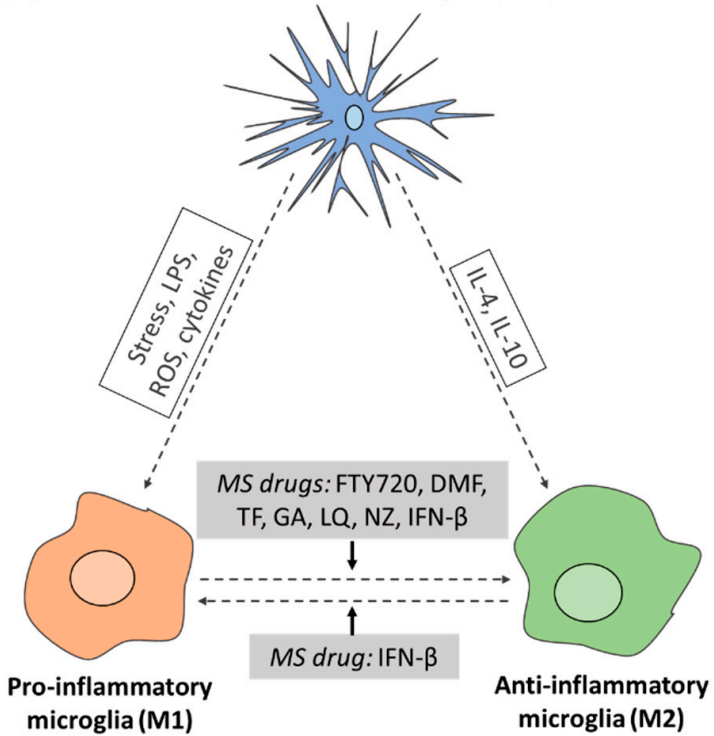

B Homeostatic astrocyte (A0)

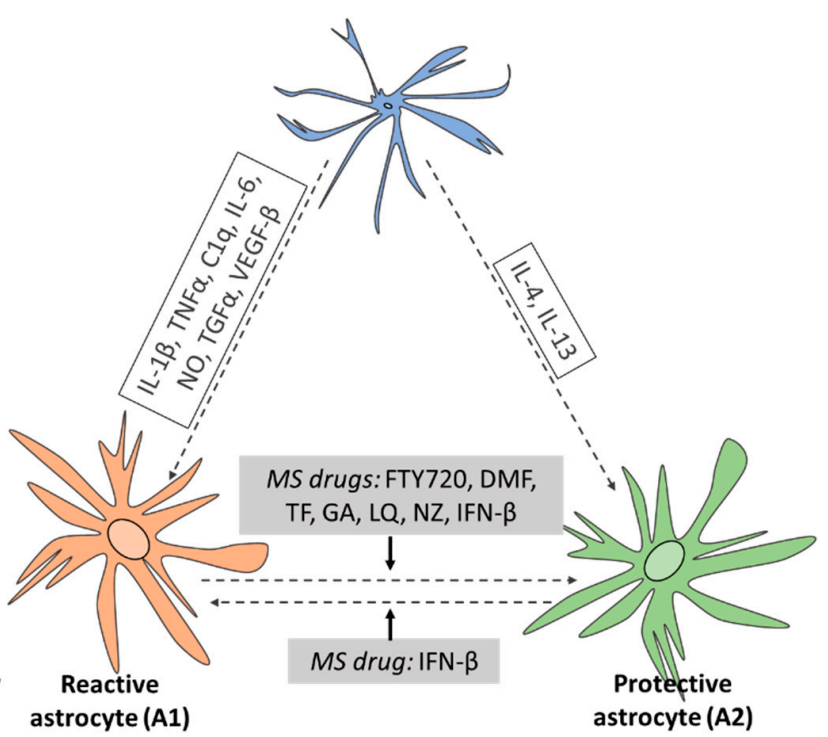

Figure 1. Effects of the environmental cues and the FDA-approved multiple sclerosis (MS) drugs on (A) the homeostatic M0 microglia becoming pro-inflammatory microglia (M1) or the anti-inflammatory microglia (M2) and (B) the homeostatic A0 astrocytes becoming reactive astrocytes (A1) or neuroprotective astrocytes (A2). Black dotted arrows indicate a change in phenotype. Black solid arrows indicate influence 
of MS drug on the change in phenotype. FTY720: Fingolimod, DMF: Dimethyl Fumarate, TF:

Teriflunomide, GA: Glatiramer Acetate, LQ: Laquinimod, NZ: Natalizumab, IFN- $\beta$ : Interferon- $\beta$.

3.2. FDA-Approved MS Drugs Induce the Transition from a Reactive into a Neuroprotective Astrocytic Phenotype

Of the drugs and CNS cell types reviewed here, most clear are the in vitro and in vivo effects of FTY720 on astrocytes. FTY720 reduced the secretion of pro-inflammatory cytokines and the reactive A1 phenotype of astrocytes. Similarly, DMF decreased the levels of pro-inflammatory cytokines secreted by astrocyte cultures and the reactive A1 astrocytic phenotype in vivo. Moreover, DMF showed clear effects on the oxidative stress response of astrocytes. As holds for the microglia phenotype, both IFN- $\beta$ and IFN- $\alpha$ modulated the astrocytic phenotype towards either a neurotoxic A1 or a neuroprotective A2 state. In addition, the two IFNs may also stabilize the BBB. Both GA and LQ decreased the astrocytic A1 reactivity in vivo, and reduced the secretion of pro-inflammatory cytokines by cultured astrocytes. Astrogliosis, as well as the expression of pro-inflammatory-linked metabolites and factors in animal models and human studies, appeared to be diminished by both NZ and OCR, although the number of pertinent studies is limited. To our knowledge, there have been no studies on the effects of TF and $\mathrm{AZ}$ on astrocytes. In sum, most FDA-approved MS drugs demonstrate the capacity to reduce the inflammatory environment in the CNS, by converting reactive A1 astrocytes into a neuroprotective A2 phenotype (Figure 1B). Comparable to what holds for microglia, this effect was evident from in vitro cellular studies as well as from studies on wild-type rodents, rodent CNS-related disease models and MS patients.

\subsection{Effects of FDA-Approved MS Drugs on the Microglial and Astrocytic Phenotypes May Be Mediated through NFKB Signaling}

$\mathrm{NF}_{\kappa} \mathrm{B}$ is the major signal transducer involved in the activation of microglia and astrocytes towards a pro-inflammatory M1 and reactive A1 phenotype, respectively [308]. This transcription factor complex, that binds to nuclear DNA elements, is responsible for activating the transcription of a wide range of pro-inflammatory cytokines, chemokines and matrix metalloproteinases, and induces oxidative stress and inflammasome activation [309,310]. Moreover, NFKB interacts and cooperates with two other nuclear signal transducers, STAT1 and STAT3 [78,79,311]. A number of studies has described an increased degree of phosphorylation of NFKB, STAT1 and STAT3 under various CNS disease and injury conditions, linking their activation to the induction of a number of pathological states [312-315]. The effects of the MS drugs on pro-inflammatory as well as anti-inflammatory factors, such as chemokines, growth factors, and oxidative stress inducers that are transcriptionally driven by NFkB (Figure 2A), strongly indicate that in microglia the NFkB pathway plays a key role in the molecular actions of these drugs. Moreover, in microglia, both FTY720 and DMF reduce the protein levels and activation of NFKB [44,55,58,77,127,129,132,143], and virtually all MS drugs modulate the expression of a remarkable number of molecular effectors upstream of NFKB, such as MAPK and PI3K/AKT [43,58,59,142,263], and other proteins known to influence NFKB signaling (Figure 2B). Similarly, in astrocytes most MS drugs discussed here affect the expression of pro-inflammatory and anti-inflammatory factors that is dependent on NFkB-induced transcriptional programs (Figure 3A). In addition, FTY720 and LQ diminish NFkB protein levels and activation $[65,84,90,92,93,98,99,267,268]$, and nearly all the MS drugs modulate the expression of MAPK and ERK1/2 [91,107,120] as well as of other NFkB-interactor proteins in astrocytes (Figure 3B). Together, these findings highlight the importance of the NFKB pathway for MS drug actions in microglia as well as astrocytes. In this connection, one should realize that the effects of the monoclonal antibodies NZ, AZ and OCR on CNS cells have not yet been sufficiently studied. Remarkably, IFN- $\beta$ seems to stimulate rather than inhibit the pro-inflammatory NFKB and STAT1 pathways [206,209,213,215,217], and the STAT1-related kinases JAK1 and TYK1 [215] in microglia and astrocytes [209,217,222,236]. 


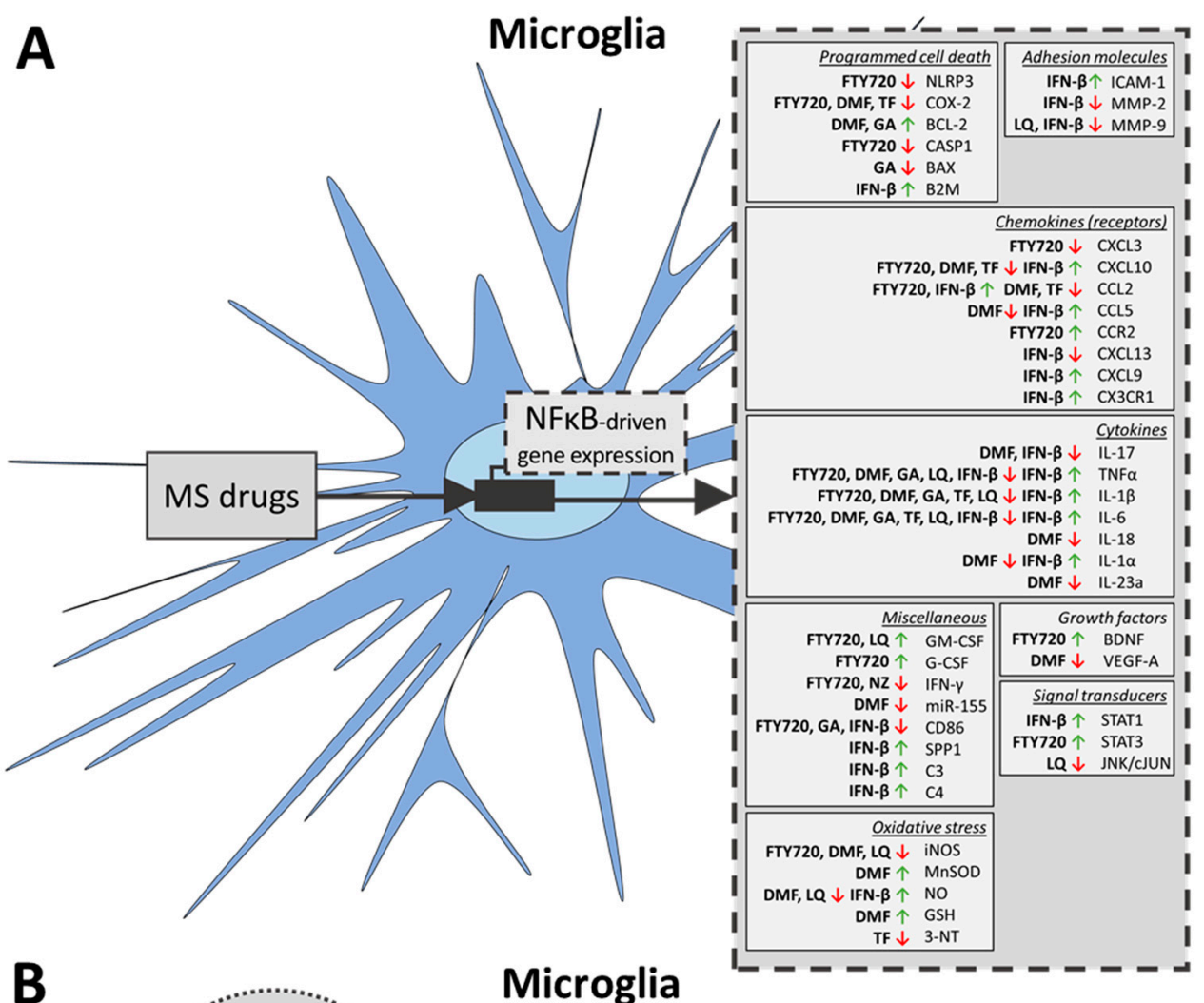

B

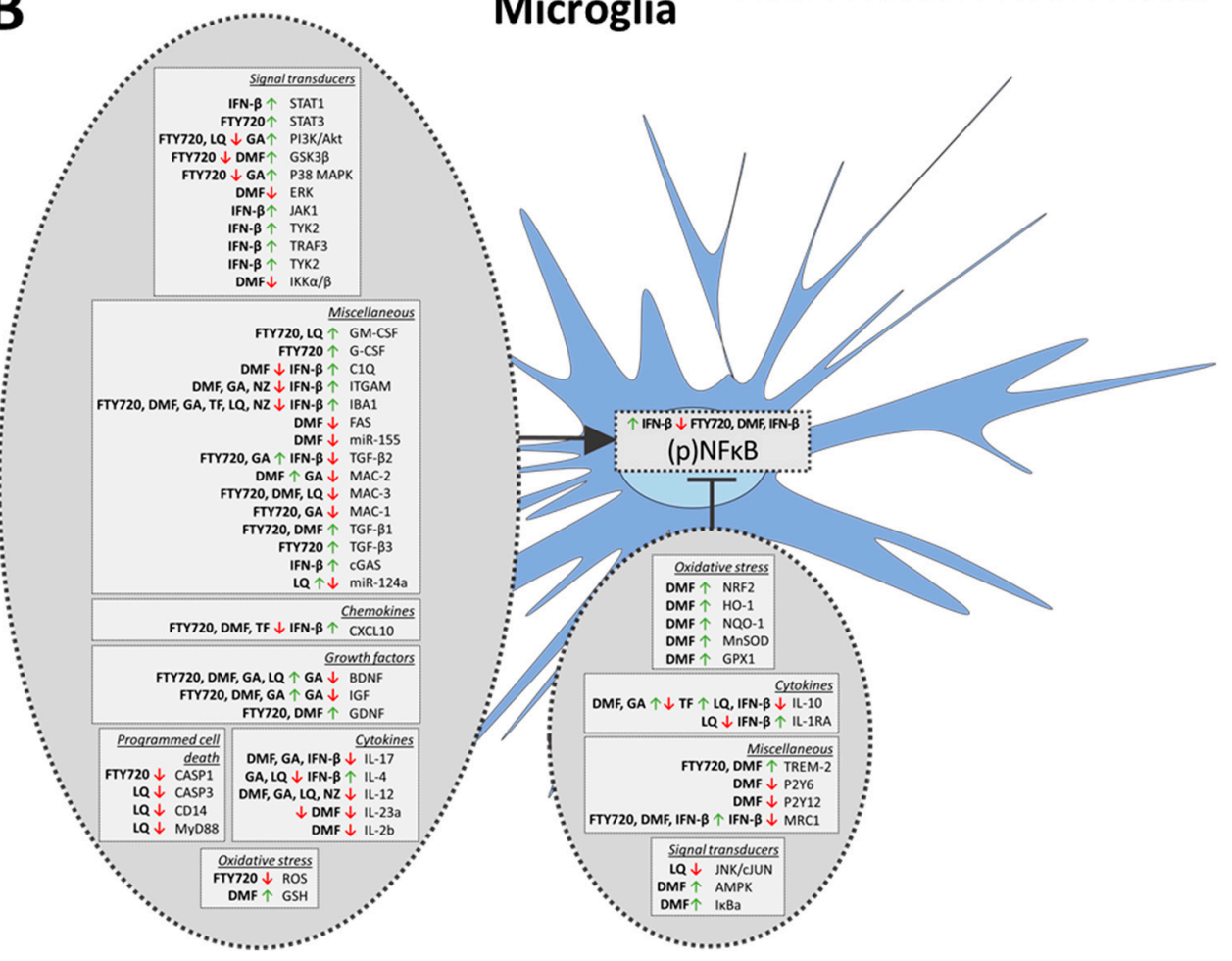

Figure 2. MS drugs directly or indirectly target NFkB signaling in microglia. The effects of MS drugs on (A) NFkB-driven gene expression and (B) the expression of genes known to affect NFkB signaling are shown. Black arrows: stimulation; bar-headed lines: inhibition; red arrows: decreased expression; green arrows: increased expression. Genes mentioned in A within the rectangular frame are under transcriptional regulation of NFKB. Genes mentioned in B within the circular frames are upstream regulators of NFKB. 

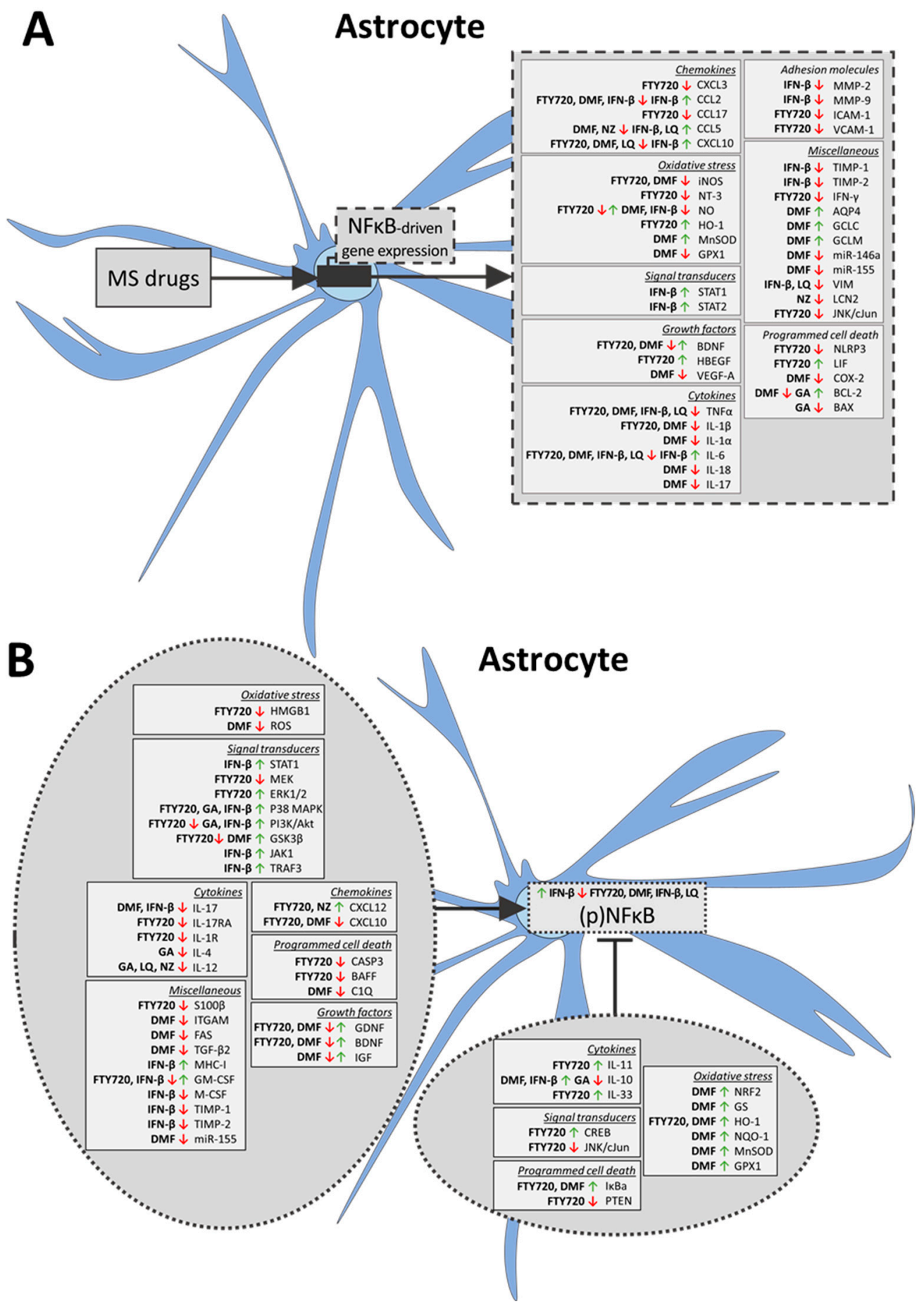

Figure 3. MS drugs directly or indirectly target NFkB signaling in astrocytes. The effects of MS drugs on (A) NFkB-driven gene expression and (B) the expression of genes known to affect NFKB signaling are shown. Black arrows: stimulation; bar-headed line: inhibition; red arrows: decreased expression; green arrows: increased expression. Genes mentioned within the rectangular frame are under transcriptional regulation of NFKB. Genes mentioned within the circular frames are upstream regulators of NFKB.

3.4. Effects of FDA-Approved MS Drugs on Neurons and Oligodendrocytes May Be Caused Indirectly by the Attenuation of the Pro-Inflammatory States of Microglia and Astrocytes

Microglia and astrocytes have a wide range of functions in the CNS, not only at baseline conditions but also in response to neuroinflammation, including providing synaptic support and maintenance, preserving metabolic homeostasis, delivering structural support, and regulating oxidative 
stress, phagocytosis of cellular debris and neuroinflammatory responses to intruders [306,316-319]. As such, microglia and astrocytes support neurons and oligodendrocytes, but they also have important interactions with each other [320]. For example, activated M1 microglia induce reactive A1 astrocytes via the secretion of cytokines such as IL-1 $\alpha, \mathrm{IL}-1 \beta$ and TNF $\alpha$ [321], as well as via the growth factors TGF- $\alpha$ and VEGF-B [322], and many other agents [320]. Conversely, reactive astrocytes increase the pro-inflammatory state of microglia by secreting factors such as CXCL10, CCL2 and LCN2 [320]. Thus, a bilateral communication occurs between microglia and astrocytes, which is important for maintaining a non-inflammatory microenvironment. In disease states, the prolonged presence of pro-inflammatory microglia and reactive astrocytes has detrimental effects on neurons and oligodendrocytes [306,307], and affects the BBB [323]. The positive effects of FDA-approved MS drugs on neurons, such as a reduction in axonal injury and neurotoxicity, and on oligodendrocytes, such as improving myelin integrity and remyelination capacity, may therefore reflect the indirect effects enabled by a reduction in the number of pro-inflammatory microglia and reactive astrocytes.

We realize that in addition to the M0/M1/M2 functional states, more types of pro- and anti-inflammatory microglia phenotypes exist and that these may have various downstream effects. For instance, the presence of microglia phenotypes associated with specific disease states, such as IFN- or LPS-induced microglia and neurodegeneration-associated microglia, has been reported [324]. Moreover, the inflammatory state of microglia may depend on their location in the brain (e.g., white matter versus grey matter) $[325,326]$. Likewise, diverse astroglia phenotypes apart from the A0/A1/A2 states have been found in a number of diseases [34].

\section{Conclusions}

In this review, we have provided an overview of the molecular effects of traditional and more recently FDA-approved MS drugs on four CNS cell types. The effects of these MS drugs on the peripheral immune system and their influence on immune cell infiltration via the BBB have been documented before, and were not specifically addressed here. From our comprehensive analysis of MS drug effects on CNS cells, we concluded that, via NFKB signaling, the majority of these drugs attenuates the pro-inflammatory M1 microglia and reactive A1 astrocytic phenotypes. On its turn, this attenuation may positively affect the functioning of diseased or injured neurons and oligodendrocytes. Such a mechanism is likely more complicated than initially thought in that microglia have recently been shown to engage a large range of activation programs which appear to be increasingly difficult to classify as purely pro-inflammatory versus anti-inflammatory [34,324]. Future characterization of the signatures of the recently described additional microglia and astrocytic subtypes, and of the extent of their pro-inflammatory or anti-inflammatory state, will aid in obtaining an even more detailed molecular understanding of the CNS mechanisms of action of drugs targeting MS. Knowledge of these molecular mechanisms may help anticipating adverse drug effects and in considering the use of combinatorial drug therapy to treat this complex neuroinflammatory disease.

Supplementary Materials: Supplementary Materials can be found at http://www.mdpi.com/1422-0067/21/12/ 4229/s1.

Author Contributions: Conceptualization, K.M.A.D.K. and G.J.M.M.; writing-original draft preparation, K.M.A.D.K.; writing-review and editing, K.M.A.D.K. and G.J.M.M.; visualization, K.M.A.D.K. and G.J.M.M.; supervision, G.J.M.M.; funding acquisition, G.J.M.M. All authors have read and agreed to the published version of the manuscript.

Funding: Kelders Beheer Ltd. (grant\#62002478).

Conflicts of Interest: The authors declare no conflict of interest.

\section{Abbreviations}

3-NT

$\mathrm{AD}$

ADCC 3-nitrotyrosine

Alzheimer's disease

Antibody-dependent cellular cytotoxicity 


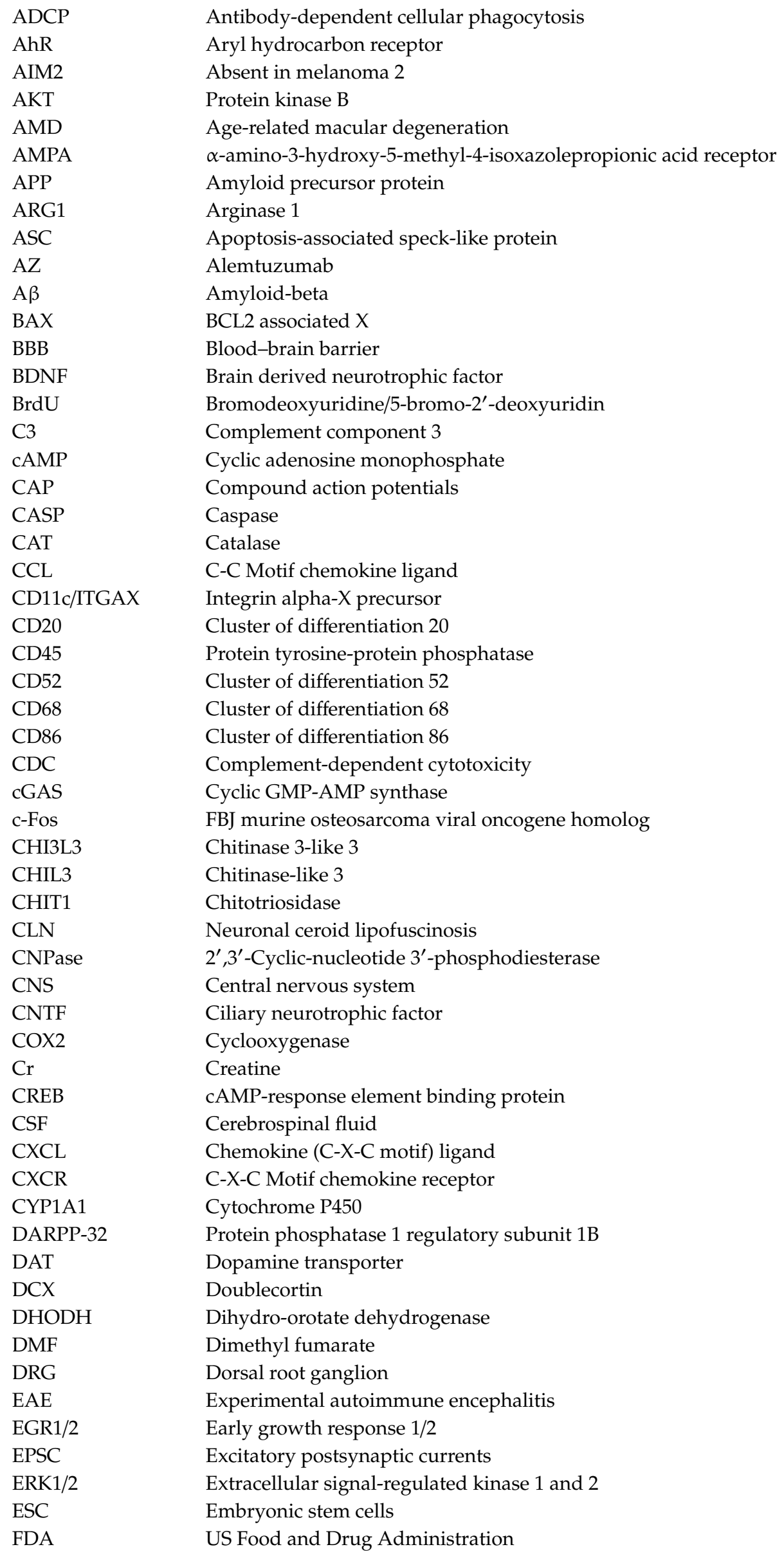


FGF2

FTY720

FTY720-pPFTY720

GA

GABA

GAP43

GDNF

GFAP

GLI1

GM-CSF

$\mathrm{GMH}$

GPI

GS

GSH

GSK3 $\beta$

$\mathrm{H} 2 \mathrm{O} 2$

HBEGF

HCAR2

HD

HDAC

HIF- $1 \alpha$

HMGB1

HO-1

HSV-1

IBA-1

ICAM-1

$\mathrm{ICH}$

IFN

IFNAR

IFN- $\alpha$

IFN- $\beta$

IFN- $\gamma$

IGF-1

IL

iNOS

IRF

$\mathrm{I} \kappa \mathrm{b} \alpha$

JAK1

JNK

JNK $1 / 2$

LBP

LCN2

LFB

LIF

LPS

LQ

MAC-1/ITGAM

MAC-2

MAC-3/CD107b

MAG

MAP2

MAPK

MASH1

MBP

MHC-I

MHC-II
Fibroblast growth factor 2

Fingolimod

Phosphorylated FTY720

Glatiramer acetate

$\gamma$-aminobutyric acid

Growth associated protein 43

Glial cell line-derived neurotrophic factor

Glial fibrillary acidic protein

GLI family zinc finger 1

Granulocyte-macrophage colony-stimulating factor

Germinal matrix hemorrhage

Glycosylphosphatidylinositol

Glutamine synthetase

Glutathione

Glycogen synthase kinase 3 beta

Hydrogen peroxide

Heparin binding EGF-like growth factor

Hydroxycarboxylic acid receptor 2

Huntington's disease

Histone deacetylase

Hypoxia-induced factor $1 \alpha$

High mobility group box 1

Heme oxygenase 1

Human herpesvirus 1

Allograft inflammatory factor 1

Intercellular adhesion molecule 1

Intracerebral hemorrhage

Interferons

IFN receptor

Interferon-alpha

Interferon-beta

Interferon-gamma

Insulin-like growth factor 1

Interleukin

Inducible nitric oxide synthase

Interferon regulatory factor

NFkB inhibitor alpha

Janus kinase 1

c-Jun N-terminal kinase

c-Jun $\mathrm{N}$-terminal kinase 1 or 2

LPS-binding protein

Lipocalin 2

Luxol Fast Blue

Leukemia inhibitory factor

Lipopolysaccharide

Laquinimod

Integrin alpha-M precursor

Galectin-3

Lysosome-associated membrane protein 2

Myelin-associated glycoprotein

Microtubule-associated protein 2

p38 mitogen-activated protein kinases

Mammalian achaete-schute homolog 1

Myelin basic protein

Major histocompatibility complex class I protein

Major histocompatibility complex class II protein 


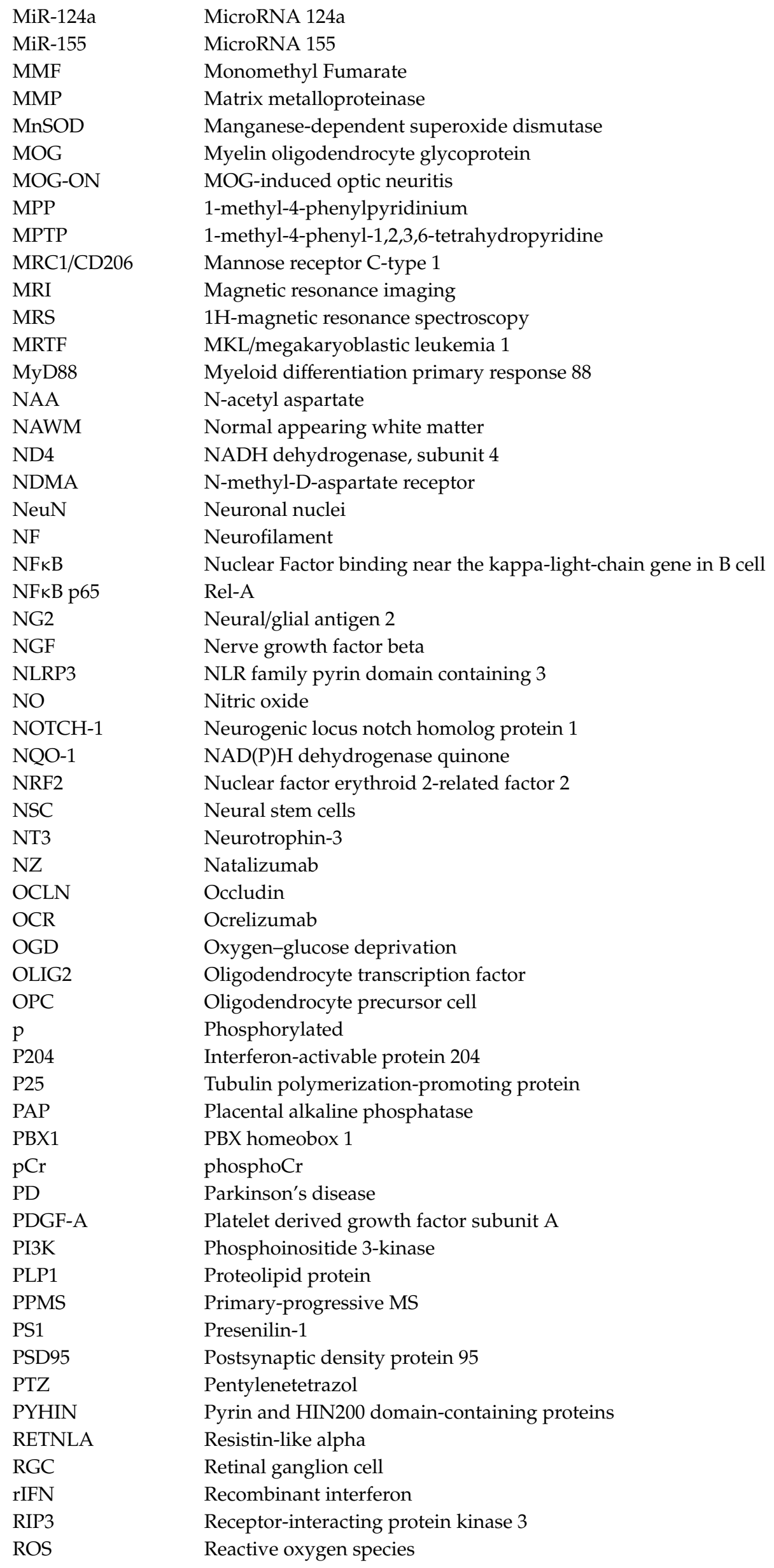




\begin{tabular}{|c|c|}
\hline RRMS & Relapsing-remitting MS \\
\hline$S 100 \beta$ & S100 calcium-binding protein B \\
\hline S1P & Sphingosine 1-phosphate \\
\hline S1PR1 & $\mathrm{S} 1 \mathrm{P}$ receptor 1 \\
\hline SCI & Spinal cord injury \\
\hline SE & Status epilepticus \\
\hline $\mathrm{SHH}$ & Sonic hedgehog \\
\hline SIGLEC-1 & Sialoadhesin \\
\hline SLC1A & Solute carrier family 1 member \\
\hline SMI32 & Neurofilament-heavy chain \\
\hline $\mathrm{SMO}$ & Smoothened \\
\hline SOCS2 & Suppressor of cytokine signaling 2 \\
\hline SOD & Superoxide dismutase \\
\hline SPN2S & Spinster homolog 2 \\
\hline SREBP2 & Sterol regulatory element-binding protein 2 \\
\hline SRF & Serum response factor \\
\hline STAT & Signal transducer and activator of transcription \\
\hline sTREM-2 & Triggering receptor expressed on myeloid cells 2 \\
\hline SYP & Synaptophysin \\
\hline TAU & Tau protein \\
\hline TBI & Traumatic brain injury \\
\hline $\mathrm{TF}$ & Teriflunomide \\
\hline TGF- $\alpha$ & Transforming growth factor alpha \\
\hline TGF- $\beta 2$ & Transforming growth factor-beta 2 \\
\hline $\mathrm{TH}$ & Tyrosine hydroxylase \\
\hline TLR & Toll-like receptor \\
\hline tMCAO & Transient middle cerebral artery occlusion \\
\hline TMEM119 & Transmembrane protein 119 \\
\hline TMEV & Theiler's murine encephalomyelitis virus \\
\hline TNF- $\alpha$ & Tumor necrosis factor alpha \\
\hline TRIF & Toll like receptor adaptor molecule 1 \\
\hline TSPO & Translocator protein \\
\hline TYK1 & Leukocyte receptor tyrosine kinase \\
\hline VCAM-1 & Vascular cell adhesion protein 1 \\
\hline VEGF-B & Vascular endothelial growth factor B \\
\hline VEGF-A & Vascular endothelial growth factor A \\
\hline VGLUT1 & Vesicular glutamate transporter 1 \\
\hline VIM & Vimentin \\
\hline VLA-4/CD49d/CD29 & Very late antigen- 4 \\
\hline $\mathrm{ZO}-1$ & Zonula occludens protein-1 \\
\hline$\alpha \mathrm{SYN}$ & $\alpha$-synuclein \\
\hline$\beta$ III-Tubulin & Beta-3-tubulin \\
\hline
\end{tabular}

\section{References}

1. Lassmann, H. Multiple Sclerosis Pathology. Cold Spring Harb Perspect Med. 2018, 8. [CrossRef] [PubMed]

2. Kutzelnigg, A.; Lucchinetti, C.F.; Stadelmann, C.; Bruck, W.; Rauschka, H.; Bergmann, M.; Schmidbauer, M.; Parisi, J.E.; Lassmann, H. Cortical demyelination and diffuse white matter injury in multiple sclerosis. Brain 2005, 128, 2705-2712. [CrossRef] [PubMed]

3. Zrzavy, T.; Hametner, S.; Wimmer, I.; Butovsky, O.; Weiner, H.L.; Lassmann, H. Loss of 'homeostatic' microglia and patterns of their activation in active multiple sclerosis. Brain 2017, 140, 1900-1913. [CrossRef] [PubMed]

4. Lassmann, H. Pathogenic Mechanisms Associated With Different Clinical Courses of Multiple Sclerosis. Front Immunol. 2018, 9, 3116. [CrossRef]

5. Baecher-Allan, C.; Kaskow, B.J.; Weiner, H.L. Multiple Sclerosis: Mechanisms and Immunotherapy. Neuron 2018, 97, 742-768. [CrossRef] [PubMed] 
6. Bachiller, S.; Jimenez-Ferrer, I.; Paulus, A.; Yang, Y.; Swanberg, M.; Deierborg, T.; Boza-Serrano, A. Microglia in Neurological Diseases: A Road Map to Brain-Disease Dependent-Inflammatory Response. Front. Cell Neurosci. 2018, 12, 488. [CrossRef] [PubMed]

7. Angelova, D.M.; Brown, D.R. Microglia and the aging brain: Are senescent microglia the key to neurodegeneration? J. Neurochem. 2019, 151, 676-688. [CrossRef]

8. Stys, P.K.; Zamponi, G.W.; van Minnen, J.; Geurts, J.J. Will the real multiple sclerosis please stand up? Nat. Rev. Neurosci. 2012, 13, 507-514. [CrossRef]

9. Traka, M.; Podojil, J.R.; McCarthy, D.P.; Miller, S.D.; Popko, B. Oligodendrocyte death results in immune-mediated CNS demyelination. Nat. Neurosci. 2016, 19, 65-74. [CrossRef]

10. Barnett, M.H.; Prineas, J.W. Relapsing and remitting multiple sclerosis: Pathology of the newly forming lesion. Ann. Neurol. 2004, 55, 458-468. [CrossRef]

11. Gholamzad, M.; Ebtekar, M.; Ardestani, M.S.; Azimi, M.; Mahmodi, Z.; Mousavi, M.J.; Aslani, S. A comprehensive review on the treatment approaches of multiple sclerosis: Currently and in the future. Inflamm. Res. 2019, 68, 25-38. [CrossRef] [PubMed]

12. Loleit, V.; Biberacher, V.; Hemmer, B. Current and future therapies targeting the immune system in multiple sclerosis. Curr. Pharm. Biotechnol. 2014, 15, 276-296. [CrossRef] [PubMed]

13. International Multiple Sclerosis Genetics, C. Multiple sclerosis genomic map implicates peripheral immune cells and microglia in susceptibility. Science 2019, 365. [CrossRef] [PubMed]

14. Graetz, C.; Groppa, S.; Zipp, F.; Siller, N. Preservation of neuronal function as measured by clinical and MRI endpoints in relapsing-remitting multiple sclerosis: How effective are current treatment strategies? Expert Rev. Neurother. 2018, 18, 203-219. [CrossRef]

15. Kuhle, J.; Kropshofer, H.; Haering, D.A.; Kundu, U.; Meinert, R.; Barro, C.; Dahlke, F.; Tomic, D.; Leppert, D.; Kappos, L. Blood neurofilament light chain as a biomarker of MS disease activity and treatment response. Neurology 2019, 92, e1007-e1015. [CrossRef] [PubMed]

16. Wattjes, M.P.; Rovira, A.; Miller, D.; Yousry, T.A.; Sormani, M.P.; de Stefano, M.P.; Tintore, M.; Auger, C.; Tur, C.; Filippi, M.; et al. Evidence-based guidelines: MAGNIMS consensus guidelines on the use of MRI in multiple sclerosis-establishing disease prognosis and monitoring patients. Nat. Rev. Neurol. 2015, 11, 597-606. [CrossRef]

17. Kihara, Y. Systematic Understanding of Bioactive Lipids in Neuro-Immune Interactions: Lessons from an Animal Model of Multiple Sclerosis. Adv. Exp. Med. Biol. 2019, 1161, 133-148. [CrossRef]

18. Candido, K.; Soufi, H.; Bandyopadhyay, M.; Dasgupta, S. Therapeutic Impact of Sphingosine 1-phosphate Receptor Signaling in Multiple Sclerosis. Mini. Rev. Med. Chem. 2016, 16, 547-554. [CrossRef]

19. Groves, A.; Kihara, Y.; Chun, J. Fingolimod: Direct CNS effects of sphingosine 1-phosphate (S1P) receptor modulation and implications in multiple sclerosis therapy. J. Neurol. Sci. 2013, 328, 9-18. [CrossRef]

20. Miller, L.G., Jr.; Young, J.A.; Ray, S.K.; Wang, G.; Purohit, S.; Banik, N.L.; Dasgupta, S. Sphingosine Toxicity in EAE and MS: Evidence for Ceramide Generation via Serine-Palmitoyltransferase Activation. Neurochem Res. 2017, 42, 2755-2768. [CrossRef]

21. Bruck, J.; Dringen, R.; Amasuno, A.; Pau-Charles, I.; Ghoreschi, K. A review of the mechanisms of action of dimethylfumarate in the treatment of psoriasis. Exp. Dermatol. 2018, 27, 611-624. [CrossRef] [PubMed]

22. Yazdi, A.; Ghasemi-Kasman, M.; Javan, M. Possible regenerative effects of fingolimod (FTY720) in multiple sclerosis disease: An overview on remyelination process. J. Neurosci. Res. 2020, 98, 524-536. [CrossRef] [PubMed]

23. Hunter, S.F.; Bowen, J.D.; Reder, A.T. The Direct Effects of Fingolimod in the Central Nervous System: Implications for Relapsing Multiple Sclerosis. CNS Drugs 2016, 30, 135-147. [CrossRef] [PubMed]

24. Liddell, J.R. Are Astrocytes the Predominant Cell Type for Activation of Nrf2 in Aging and Neurodegeneration? Antioxidants (Basel) 2017, 6, 65. [CrossRef] [PubMed]

25. Chen-Roetling, J.; Regan, R.F. Targeting the Nrf2-Heme Oxygenase-1 Axis after Intracerebral Hemorrhage. Curr Pharm. Des. 2017, 23, 2226-2237. [CrossRef]

26. Liblau, R. Glatiramer acetate for the treatment of multiple sclerosis: Evidence for a dual anti-inflammatory and neuroprotective role. J. Neurol. Sci. 2009, 287, S17-S23. [CrossRef]

27. Arnon, R.; Aharoni, R. Neurogenesis and neuroprotection in the CNS-fundamental elements in the effect of Glatiramer acetate on treatment of autoimmune neurological disorders. Mol. Neurobiol. 2007, 36, 245-253. [CrossRef] 
28. Dhib-Jalbut, S. Mechanisms of action of interferons and glatiramer acetate in multiple sclerosis. Neurology 2002, 58, S3-S9. [CrossRef]

29. Sellebjerg, F.; Cadavid, D.; Steiner, D.; Villar, L.M.; Reynolds, R.; Mikol, D. Exploring potential mechanisms of action of natalizumab in secondary progressive multiple sclerosis. Ther. Adv. Neurol. Disord. 2016, 9 , 31-43. [CrossRef]

30. Kieseier, B.C. Defining a role for laquinimod in multiple sclerosis. Ther. Adv. Neurol. Disord. 2014, 7, $195-205$. [CrossRef]

31. Bruck, W.; Wegner, C. Insight into the mechanism of laquinimod action. J. Neurol. Sci. 2011, 306, $173-179$. [CrossRef] [PubMed]

32. Orihuela, R.; McPherson, C.A.; Harry, G.J. Microglial M1/M2 polarization and metabolic states. Br. J. Pharmacol. 2016, 173, 649-665. [CrossRef] [PubMed]

33. Tang, Y.; Le, W. Differential Roles of M1 and M2 Microglia in Neurodegenerative Diseases. Mol. Neurobiol. 2016, 53, 1181-1194. [CrossRef] [PubMed]

34. Miller, S.J. Astrocyte Heterogeneity in the Adult Central Nervous System. Front Cell Neurosci. 2018, $12,401$. [CrossRef] [PubMed]

35. Tsai, H.C.; Han, M.H. Sphingosine-1-Phosphate (S1P) and S1P Signaling Pathway: Therapeutic Targets in Autoimmunity and Inflammation. Drugs 2016, 76, 1067-1079. [CrossRef]

36. Prager, B.; Spampinato, S.F.; Ransohoff, R.M. Sphingosine 1-phosphate signaling at the blood-brain barrier. Trends Mol. Med. 2015, 21, 354-363. [CrossRef]

37. Wang, Z.; Kawabori, M.; Houkin, K. FTY720 (Fingolimod) Ameliorates Brain Injury Through Multiple Mechanisms and is a Strong Candidate for Stroke Treatment. Curr. Med. Chem. 2019. [CrossRef]

38. Farez, M.F.; Correale, J. Sphingosine 1-phosphate signaling in astrocytes: Implications for progressive multiple sclerosis. J. Neurol. Sci. 2016, 361, 60-65. [CrossRef]

39. Hiestand, P.C.; Rausch, M.; Meier, D.P.; Foster, C.A. Ascomycete derivative to MS therapeutic: S1P receptor modulator FTY720. Prog. Drug Res. 2008, 66, 361, 363-381. [CrossRef]

40. Park, S.J.; Im, D.S. Sphingosine 1-Phosphate Receptor Modulators and Drug Discovery. Biomol. Ther. (Seoul) 2017, 25, 80-90. [CrossRef]

41. Foster, C.A.; Howard, L.M.; Schweitzer, A.; Persohn, E.; Hiestand, P.C.; Balatoni, B.; Reuschel, R.; Beerli, C.; Schwartz, M.; Billich, A. Brain penetration of the oral immunomodulatory drug FTY720 and its phosphorylation in the central nervous system during experimental autoimmune encephalomyelitis: Consequences for mode of action in multiple sclerosis. J. Pharmacol. Exp. Ther. 2007, 323, 469-475. [CrossRef] [PubMed]

42. Shang, K.; He, J.; Zou, J.; Qin, C.; Lin, L.; Zhou, L.Q.; Yang, L.L.; Wu, L.J.; Wang, W.; Zhan, K.B.; et al. Fingolimod promotes angiogenesis and attenuates ischemic brain damage via modulating microglial polarization. Brain Res. 2020, 1726, 146509. [CrossRef] [PubMed]

43. Qin, C.; Fan, W.H.; Liu, Q.; Shang, K.; Murugan, M.; Wu, L.J.; Wang, W.; Tian, D.S. Fingolimod Protects Against Ischemic White Matter Damage by Modulating Microglia Toward M2 Polarization via STAT3 Pathway. Stroke 2017, 48, 3336-3346. [CrossRef] [PubMed]

44. Zhong, L.; Jiang, X.; Zhu, Z.; Qin, H.; Dinkins, M.B.; Kong, J.N.; Leanhart, S.; Wang, R.; Elsherbini, A.; Bieberich, E.; et al. Lipid transporter Spns2 promotes microglia pro-inflammatory activation in response to amyloid-beta peptide. Glia 2019, 67, 498-511. [CrossRef] [PubMed]

45. Carreras, I.; Aytan, N.; Choi, J.K.; Tognoni, C.M.; Kowall, N.W.; Jenkins, B.G.; Dedeoglu, A. Dual dose-dependent effects of fingolimod in a mouse model of Alzheimer's disease. Sci. Rep. 2019, 9, 10972. [CrossRef] [PubMed]

46. Metzdorf, J.; Hobloss, Z.; Schlevogt, S.; Ayzenberg, I.; Stahlke, S.; Pedreiturria, X.; Haupeltshofer, S.; Gold, R.; Tonges, L.; Kleiter, I. Fingolimod for Irradiation-Induced Neurodegeneration. Front Neurosci. 2019, 13, 699. [CrossRef] [PubMed]

47. Yang, Z.; Dong, S.; Zheng, Q.; Zhang, L.; Tan, X.; Zou, J.; Yan, B.; Chen, Y. FTY720 attenuates iron deposition and glial responses in improving delayed lesion and long-term outcomes of collagenase-induced intracerebral hemorrhage. Brain Res. 2019, 1718, 91-102. [CrossRef]

48. Kim, S.; Bielawski, J.; Yang, H.; Kong, Y.; Zhou, B.; Li, J. Functional antagonism of sphingosine-1-phosphate receptor 1 prevents cuprizone-induced demyelination. Glia 2018, 66, 654-669. [CrossRef] 
49. Groh, J.; Berve, K.; Martini, R. Fingolimod and Teriflunomide Attenuate Neurodegeneration in Mouse Models of Neuronal Ceroid Lipofuscinosis. Mol. Ther. 2017, 25, 1889-1899. [CrossRef]

50. Lee, D.H.; Seubert, S.; Huhn, K.; Brecht, L.; Rotger, C.; Waschbisch, A.; Schlachetzki, J.; Klausmeyer, A.; Melms, A.; Wiese, S.; et al. Fingolimod effects in neuroinflammation: Regulation of astroglial glutamate transporters? PLoS ONE 2017, 12, e0171552. [CrossRef]

51. Aytan, N.; Choi, J.K.; Carreras, I.; Brinkmann, V.; Kowall, N.W.; Jenkins, B.G.; Dedeoglu, A. Fingolimod modulates multiple neuroinflammatory markers in a mouse model of Alzheimer's disease. Sci. Rep. 2016, 6, 24939. [CrossRef] [PubMed]

52. Serdar, M.; Herz, J.; Kempe, K.; Lumpe, K.; Reinboth, B.S.; Sizonenko, S.V.; Hou, X.; Herrmann, R.; Hadamitzky, M.; Heumann, R.; et al. Fingolimod protects against neonatal white matter damage and long-term cognitive deficits caused by hyperoxia. Brain Behav. Immun. 2016, 52, 106-119. [CrossRef] [PubMed]

53. Wei, Y.; Yemisci, M.; Kim, H.H.; Yung, L.M.; Shin, H.K.; Hwang, S.K.; Guo, S.; Qin, T.; Alsharif, N.; Brinkmann, V.; et al. Fingolimod provides long-term protection in rodent models of cerebral ischemia. Ann. Neurol. 2011, 69, 119-129. [CrossRef] [PubMed]

54. Gao, F.; Liu, Y.; Li, X.; Wang, Y.; Wei, D.; Jiang, W. Fingolimod (FTY720) inhibits neuroinflammation and attenuates spontaneous convulsions in lithium-pilocarpine induced status epilepticus in rat model. Pharmacol. Biochem. Behav. 2012, 103, 187-196. [CrossRef]

55. Ji, J.; Wang, J.; Yang, J.; Wang, X.P.; Huang, J.J.; Xue, T.F.; Sun, X.L. The Intra-nuclear SphK2-S1P Axis Facilitates M1-to-M2 Shift of Microglia via Suppressing HDAC1-Mediated KLF4 Deacetylation. Front Immunol. 2019, 10, 1241. [CrossRef]

56. Gol, M.; Ghorbanian, D.; Hassanzadeh, S.; Javan, M.; Mirnajafi-Zadeh, J.; Ghasemi-Kasman, M. Fingolimod enhances myelin repair of hippocampus in pentylenetetrazol-induced kindling model. Eur. J. Pharm. Sci. 2017, 96, 72-83. [CrossRef]

57. Rau, C.R.; Hein, K.; Sattler, M.B.; Kretzschmar, B.; Hillgruber, C.; McRae, B.L.; Diem, R.; Bahr, M. Anti-inflammatory effects of FTY720 do not prevent neuronal cell loss in a rat model of optic neuritis. Am. J. Pathol. 2011, 178, 1770-1781. [CrossRef]

58. Yao, S.; Li, L.; Sun, X.; Hua, J.; Zhang, K.; Hao, L.; Liu, L.; Shi, D.; Zhou, H. FTY720 Inhibits MPP(+)-Induced Microglial Activation by Affecting NLRP3 Inflammasome Activation. J. Neuroimmune. Pharmacol. 2019, 14, 478-492. [CrossRef]

59. Cipriani, R.; Chara, J.C.; Rodriguez-Antiguedad, A.; Matute, C. FTY720 attenuates excitotoxicity and neuroinflammation. J. Neuroinflammation 2015, 12, 86. [CrossRef]

60. Balatoni, B.; Storch, M.K.; Swoboda, E.M.; Schonborn, V.; Koziel, A.; Lambrou, G.N.; Hiestand, P.C.; Weissert, R.; Foster, C.A. FTY720 sustains and restores neuronal function in the DA rat model of MOG-induced experimental autoimmune encephalomyelitis. Brain Res. Bull 2007, 74, 307-316. [CrossRef]

61. Smith, P.A.; Schmid, C.; Zurbruegg, S.; Jivkov, M.; Doelemeyer, A.; Theil, D.; Dubost, V.; Beckmann, N. Fingolimod inhibits brain atrophy and promotes brain-derived neurotrophic factor in an animal model of multiple sclerosis. J. Neuroimmunol 2018, 318, 103-113. [CrossRef] [PubMed]

62. Vidal-Martinez, G.; Segura-Ulate, I.; Yang, B.; Diaz-Pacheco, V.; Barragan, J.A.; De-Leon Esquivel, J.; Chaparro, S.A.; Vargas-Medrano, J.; Perez, R.G. FTY720-Mitoxy reduces synucleinopathy and neuroinflammation, restores behavior and mitochondria function, and increases GDNF expression in Multiple System Atrophy mouse models. Exp. Neurol. 2020, 325, 113120. [CrossRef] [PubMed]

63. Marfia, G.; Navone, S.E.; Hadi, L.A.; Paroni, M.; Berno, V.; Beretta, M.; Gualtierotti, R.; Ingegnoli, F.; Levi, V.; Miozzo, M.; et al. The Adipose Mesenchymal Stem Cell Secretome Inhibits Inflammatory Responses of Microglia: Evidence for an Involvement of Sphingosine-1-Phosphate Signalling. Stem Cells Dev. 2016, 25, 1095-1107. [CrossRef] [PubMed]

64. Bechet, S.; O'Sullivan, S.A.; Yssel, J.; Fagan, S.G.; Dev, K.K. Fingolimod Rescues Demyelination in a Mouse Model of Krabbe's Disease. J. Neurosci. 2020, 40, 3104-3118. [CrossRef]

65. Rothhammer, V.; Kenison, J.E.; Tjon, E.; Takenaka, M.C.; de Lima, K.A.; Borucki, D.M.; Chao, C.C.; Wilz, A.; Blain, M.; Healy, L.; et al. Sphingosine 1-phosphate receptor modulation suppresses pathogenic astrocyte activation and chronic progressive CNS inflammation. Proc. Natl. Acad. Sci. USA 2017, 114, 2012-2017. [CrossRef] 
66. Miron, V.E.; Ludwin, S.K.; Darlington, P.J.; Jarjour, A.A.; Soliven, B.; Kennedy, T.E.; Antel, J.P. Fingolimod (FTY720) enhances remyelination following demyelination of organotypic cerebellar slices. Am. J. Pathol. 2010, 176, 2682-2694. [CrossRef]

67. Alme, M.N.; Nystad, A.E.; Bo, L.; Myhr, K.M.; Vedeler, C.A.; Wergeland, S.; Torkildsen, O. Fingolimod does not enhance cerebellar remyelination in the cuprizone model. J. Neuroimmunol. 2015, 285, 180-186. [CrossRef]

68. Slowik, A.; Schmidt, T.; Beyer, C.; Amor, S.; Clarner, T.; Kipp, M. The sphingosine 1-phosphate receptor agonist FTY720 is neuroprotective after cuprizone-induced CNS demyelination. Br. J. Pharmacol. 2015, 172, 80-92. [CrossRef]

69. Nystad, A.E.; Lereim, R.R.; Wergeland, S.; Oveland, E.; Myhr, K.M.; Bo, L.; Torkildsen, O. Fingolimod downregulates brain sphingosine-1-phosphate receptor 1 levels but does not promote remyelination or neuroprotection in the cuprizone model. J. Neuroimmunol. 2020, 339, 577091. [CrossRef]

70. Anastasiadou, S.; Knoll, B. The multiple sclerosis drug fingolimod (FTY720) stimulates neuronal gene expression, axonal growth and regeneration. Exp. Neurol. 2016, 279, 243-260. [CrossRef]

71. Anthony, D.C.; Dickens, A.M.; Seneca, N.; Couch, Y.; Campbell, S.; Checa, B.; Kersemans, V.; Warren, E.A.; Tredwell, M.; Sibson, N.R.; et al. Anti-CD20 inhibits T cell-mediated pathology and microgliosis in the rat brain. Ann. Clin. Transl. Neurol. 2014, 1, 659-669. [CrossRef] [PubMed]

72. Noda, H.; Takeuchi, H.; Mizuno, T.; Suzumura, A. Fingolimod phosphate promotes the neuroprotective effects of microglia. J. Neuroimmunol. 2013, 256, 13-18. [CrossRef] [PubMed]

73. O'Sullivan, S.A.; O'Sullivan, C.; Healy, L.M.; Dev, K.K.; Sheridan, G.K. Sphingosine 1-phosphate receptors regulate TLR4-induced CXCL5 release from astrocytes and microglia. J. Neurochem. 2018, 144, 736-747. [CrossRef] [PubMed]

74. Das, A.; Arifuzzaman, S.; Kim, S.H.; Lee, Y.S.; Jung, K.H.; Chai, Y.G. FTY720 (fingolimod) regulates key target genes essential for inflammation in microglial cells as defined by high-resolution mRNA sequencing. Neuropharmacology 2017, 119, 1-14. [CrossRef] [PubMed]

75. Zhang, Z.; Fauser, U.; Schluesener, H.J. Early attenuation of lesional interleukin-16 up-regulation by dexamethasone and FTY720 in experimental traumatic brain injury. Neuropathol. Appl. Neurobiol. 2008, 34, 330-339. [CrossRef] [PubMed]

76. Newton, K.; Dixit, V.M. Signaling in innate immunity and inflammation. Cold Spring Harb Perspect Biol. 2012, 4. [CrossRef]

77. Scheiblich, H.; Schlutter, A.; Golenbock, D.T.; Latz, E.; Martinez-Martinez, P.; Heneka, M.T. Activation of the NLRP3 inflammasome in microglia: The role of ceramide. J. Neurochem. 2017, 143, 534-550. [CrossRef]

78. Grivennikov, S.I.; Karin, M. Dangerous liaisons: STAT3 and NF-kappaB collaboration and crosstalk in cancer. Cytokine Growth Factor Rev. 2010, 21, 11-19. [CrossRef]

79. Fan, Y.; Mao, R.; Yang, J. NF-kappaB and STAT3 signaling pathways collaboratively link inflammation to cancer. Protein Cell 2013, 4, 176-185. [CrossRef]

80. Yoshino, T.; Tabunoki, H.; Sugiyama, S.; Ishii, K.; Kim, S.U.; Satoh, J. Non-phosphorylated FTY720 induces apoptosis of human microglia by activating SREBP2. Cell Mol. Neurobiol. 2011, 31, 1009-1020. [CrossRef]

81. Ruiz, A.; Joshi, P.; Mastrangelo, R.; Francolini, M.; Verderio, C.; Matteoli, M. Testing Abeta toxicity on primary CNS cultures using drug-screening microfluidic chips. Lab. Chip 2014, 14, 2860-2866. [CrossRef] [PubMed]

82. Choi, J.W.; Gardell, S.E.; Herr, D.R.; Rivera, R.; Lee, C.W.; Noguchi, K.; Teo, S.T.; Yung, Y.C.; Lu, M.; Kennedy, G.; et al. FTY720 (fingolimod) efficacy in an animal model of multiple sclerosis requires astrocyte sphingosine 1-phosphate receptor 1 (S1P1) modulation. Proc. Natl. Acad. Sci. USA 2011, 108, 751-756. [CrossRef] [PubMed]

83. Mullershausen, F.; Craveiro, L.M.; Shin, Y.; Cortes-Cros, M.; Bassilana, F.; Osinde, M.; Wishart, W.L.; Guerini, D.; Thallmair, M.; Schwab, M.E.; et al. Phosphorylated FTY720 promotes astrocyte migration through sphingosine-1-phosphate receptors. J. Neurochem. 2007, 102, 1151-1161. [CrossRef] [PubMed]

84. Miguez, A.; Garcia-Diaz Barriga, G.; Brito, V.; Straccia, M.; Giralt, A.; Gines, S.; Canals, J.M.; Alberch, J. Fingolimod (FTY720) enhances hippocampal synaptic plasticity and memory in Huntington's disease by preventing p75NTR up-regulation and astrocyte-mediated inflammation. Hum. Mol. Genet. 2015, 24, 4958-4970. [CrossRef] 
85. McManus, R.M.; Finucane, O.M.; Wilk, M.M.; Mills, K.H.G.; Lynch, M.A. FTY720 Attenuates Infection-Induced Enhancement of Abeta Accumulation in APP/PS1 Mice by Modulating Astrocytic Activation. J. Neuroimmune. Pharmacol. 2017, 12, 670-681. [CrossRef]

86. Brunkhorst, R.; Kanaan, N.; Koch, A.; Ferreiros, N.; Mirceska, A.; Zeiner, P.; Mittelbronn, M.; Derouiche, A.; Steinmetz, H.; Foerch, C.; et al. FTY720 treatment in the convalescence period improves functional recovery and reduces reactive astrogliosis in photothrombotic stroke. PLoS ONE 2013, 8, e70124. [CrossRef]

87. Yavuz, A.; Sezik, M.; Ozmen, O.; Asci, H. Fingolimod against endotoxin-induced fetal brain injury in a rat model. J. Obstet. Gynaecol. Res. 2017, 43, 1708-1713. [CrossRef]

88. Yazdi, A.; Mokhtarzadeh Khanghahi, A.; Baharvand, H.; Javan, M. Fingolimod Enhances Oligodendrocyte Differentiation of Transplanted Human Induced Pluripotent Stem Cell-Derived Neural Progenitors. Iran J. Pharm. Res. 2018, 17, 1444-1457.

89. Spampinato, S.F.; Obermeier, B.; Cotleur, A.; Love, A.; Takeshita, Y.; Sano, Y.; Kanda, T.; Ransohoff, R.M. Sphingosine 1 Phosphate at the Blood Brain Barrier: Can the Modulation of S1P Receptor 1 Influence the Response of Endothelial Cells and Astrocytes to Inflammatory Stimuli? PLoS ONE 2015, 10, e0133392. [CrossRef]

90. Lee, B.J.; Kim, J.Y.; Cho, H.J.; Park, D. Sphingosine 1-phosphate receptor modulation attenuate mechanical allodynia in mouse model of chronic complex regional pain syndrome by suppressing pathogenic astrocyte activation. Reg. Anesth Pain Med. 2020. [CrossRef]

91. Weinstock, L.D.; Furness, A.M.; Herron, S.S.; Smith, S.S.; Sankar, S.B.; DeRosa, S.G.; Gao, D.; Mepyans, M.E.; Scotto Rosato, A.; Medina, D.L.; et al. Fingolimod phosphate inhibits astrocyte inflammatory activity in mucolipidosis IV. Hum. Mol. Genet 2018, 27, 2725-2738. [CrossRef] [PubMed]

92. Colombo, E.; Di Dario, M.; Capitolo, E.; Chaabane, L.; Newcombe, J.; Martino, G.; Farina, C. Fingolimod may support neuroprotection via blockade of astrocyte nitric oxide. Ann. Neurol. 2014, 76, 325-337. [CrossRef] [PubMed]

93. Dong, Y.F.; Guo, R.B.; Ji, J.; Cao, L.L.; Zhang, L.; Chen, Z.Z.; Huang, J.Y.; Wu, J.; Lu, J.; Sun, X.L. S1PR3 is essential for phosphorylated fingolimod to protect astrocytes against oxygen-glucose deprivation-induced neuroinflammation via inhibiting TLR2/4-NFkappaB signalling. J. Cell Mol. Med. 2018, 22, 3159-3166. [CrossRef] [PubMed]

94. Pang, X.; Hou, X. Synergistic protective effect of FTY720 and vitamin E against simulated cerebral ischemia in vitro. Mol. Med. Rep. 2017, 16, 396-402. [CrossRef] [PubMed]

95. Hoffmann, F.S.; Hofereiter, J.; Rubsamen, H.; Melms, J.; Schwarz, S.; Faber, H.; Weber, P.; Putz, B.; Loleit, V.; Weber, F.; et al. Fingolimod induces neuroprotective factors in human astrocytes. J. Neuroinflammation 2015, 12, 184. [CrossRef] [PubMed]

96. Janssen, S.; Schlegel, C.; Gudi, V.; Prajeeth, C.K.; Skripuletz, T.; Trebst, C.; Stangel, M. Effect of FTY720-phosphate on the expression of inflammation-associated molecules in astrocytes in vitro. Mol. Med. Rep 2015, 12, 6171-6177. [CrossRef]

97. Groves, A.; Kihara, Y.; Jonnalagadda, D.; Rivera, R.; Kennedy, G.; Mayford, M.; Chun, J. A Functionally Defined In Vivo Astrocyte Population Identified by c-Fos Activation in a Mouse Model of Multiple Sclerosis Modulated by S1P Signaling: Immediate-Early Astrocytes (ieAstrocytes). eNeuro 2018, 5. [CrossRef]

98. Trkov Bobnar, S.; Stenovec, M.; Mis, K.; Pirkmajer, S.; Zorec, R. Fingolimod Suppresses the Proinflammatory Status of Interferon-gamma-Activated Cultured Rat Astrocytes. Mol. Neurobiol. 2019, 56, 5971-5986. [CrossRef]

99. Doyle, T.M.; Chen, Z.; Durante, M.; Salvemini, D. Activation of Sphingosine-1-Phosphate Receptor 1 in the Spinal Cord Produces Mechanohypersensitivity Through the Activation of Inflammasome and IL-1beta Pathway. J. Pain 2019, 20, 956-964. [CrossRef]

100. Saha, R.N.; Jana, M.; Pahan, K. MAPK p38 regulates transcriptional activity of NF-kappaB in primary human astrocytes via acetylation of p65. J. Immunol. 2007, 179, 7101-7109. [CrossRef]

101. Somensi, N.; Brum, P.O.; de Miranda Ramos, V.; Gasparotto, J.; Zanotto-Filho, A.; Rostirolla, D.C.; da Silva Morrone, M.; Moreira, J.C.F.; Pens Gelain, D. Extracellular HSP70 Activates ERK1/2, NF-kB and Pro-Inflammatory Gene Transcription Through Binding with RAGE in A549 Human Lung Cancer Cells. Cell Physiol. Biochem. 2017, 42, 2507-2522. [CrossRef] [PubMed] 
102. Wang, J.; Wang, J.; Lu, P.; Cai, Y.; Wang, Y.; Hong, L.; Ren, H.; Heng, B.C.; Liu, H.; Zhou, J.; et al. Local delivery of FTY720 in PCL membrane improves SCI functional recovery by reducing reactive astrogliosis. Biomaterials 2015, 62, 76-87. [CrossRef]

103. van Doorn, R.; Nijland, P.G.; Dekker, N.; Witte, M.E.; Lopes-Pinheiro, M.A.; van het Hof, B.; Kooij, G.; Reijerkerk, A.; Dijkstra, C.; van van der Valk, P.; et al. Fingolimod attenuates ceramide-induced blood-brain barrier dysfunction in multiple sclerosis by targeting reactive astrocytes. Acta. Neuropathol. 2012, 124, 397-410. [CrossRef] [PubMed]

104. Healy, L.M.; Sheridan, G.K.; Pritchard, A.J.; Rutkowska, A.; Mullershausen, F.; Dev, K.K. Pathway specific modulation of S1P1 receptor signalling in rat and human astrocytes. Br. J. Pharmacol. 2013, 169, 1114-1129. [CrossRef] [PubMed]

105. Luchtman, D.; Gollan, R.; Ellwardt, E.; Birkenstock, J.; Robohm, K.; Siffrin, V.; Zipp, F. In vivo and in vitro effects of multiple sclerosis immunomodulatory therapeutics on glutamatergic excitotoxicity. J. Neurochem. 2016, 136, 971-980. [CrossRef]

106. Cipriani, R.; Chara, J.C.; Rodriguez-Antiguedad, A.; Matute, C. Effects of FTY720 on brain neurogenic niches in vitro and after kainic acid-induced injury. J. Neuroinflammation 2017, 14, 147. [CrossRef] [PubMed]

107. Cui, Q.L.; Fang, J.; Kennedy, T.E.; Almazan, G.; Antel, J.P. Role of p38MAPK in S1P receptor-mediated differentiation of human oligodendrocyte progenitors. Glia 2014, 62, 1361-1375. [CrossRef]

108. Jin, Y.; Sun, L.H.; Yang, W.; Cui, R.J.; Xu, S.B. The Role of BDNF in the Neuroimmune Axis Regulation of Mood Disorders. Front Neurol. 2019, 10, 515. [CrossRef]

109. Traiffort, E.; Kassoussi, A.; Zahaf, A.; Laouarem, Y. Astrocytes and Microglia as Major Players of Myelin Production in Normal and Pathological Conditions. Front Cell Neurosci. 2020, 14, 79. [CrossRef]

110. Yasuda, K.; Maki, T.; Saito, S.; Yamamoto, Y.; Kinoshita, H.; Choi, Y.K.; Arumugam, T.V.; Lim, Y.A.; Chen, C.L.H.; Wong, P.T.; et al. Effect of fingolimod on oligodendrocyte maturation under prolonged cerebral hypoperfusion. Brain Res. 2019, 1720, 146294. [CrossRef]

111. Yazdi, A.; Baharvand, H.; Javan, M. Enhanced remyelination following lysolecithin-induced demyelination in mice under treatment with fingolimod (FTY720). Neuroscience 2015, 311, 34-44. [CrossRef] [PubMed]

112. Caprariello, A.V.; Batt, C.E.; Zippe, I.; Romito-DiGiacomo, R.R.; Karl, M.; Miller, R.H. Apoptosis of Oligodendrocytes during Early Development Delays Myelination and Impairs Subsequent Responses to Demyelination. J. Neurosci. 2015, 35, 14031-14041. [CrossRef] [PubMed]

113. Dulamea, A.O. Role of Oligodendrocyte Dysfunction in Demyelination, Remyelination and Neurodegeneration in Multiple Sclerosis. Adv. Exp. Med. Biol. 2017, 958, 91-127. [CrossRef] [PubMed]

114. Coelho, R.P.; Payne, S.G.; Bittman, R.; Spiegel, S.; Sato-Bigbee, C. The immunomodulator FTY720 has a direct cytoprotective effect in oligodendrocyte progenitors. J. Pharmacol. Exp. Ther. 2007, 323, 626-635. [CrossRef] [PubMed]

115. Bieberich, E. There is more to a lipid than just being a fat: Sphingolipid-guided differentiation of oligodendroglial lineage from embryonic stem cells. Neurochem. Res. 2011, 36, 1601-1611. [CrossRef] [PubMed]

116. Miron, V.E.; Jung, C.G.; Kim, H.J.; Kennedy, T.E.; Soliven, B.; Antel, J.P. FTY720 modulates human oligodendrocyte progenitor process extension and survival. Ann. Neurol. 2008, 63, 61-71. [CrossRef] [PubMed]

117. Zhang, J.; Zhang, Z.G.; Li, Y.; Ding, X.; Shang, X.; Lu, M.; Elias, S.B.; Chopp, M. Fingolimod treatment promotes proliferation and differentiation of oligodendrocyte progenitor cells in mice with experimental autoimmune encephalomyelitis. Neurobiol. Dis. 2015, 76, 57-66. [CrossRef]

118. Dasgupta, S.; Ray, S.K. Ceramide and Sphingosine Regulation of Myelinogenesis: Targeting Serine Palmitoyltransferase Using microRNA in Multiple Sclerosis. Int. J. Mol. Sci. 2019, 20, 5031. [CrossRef]

119. Pritchard, A.J.; Mir, A.K.; Dev, K.K. Fingolimod attenuates splenocyte-induced demyelination in cerebellar slice cultures. PLoS ONE 2014, 9, e99444. [CrossRef]

120. Osinde, M.; Mullershausen, F.; Dev, K.K. Phosphorylated FTY720 stimulates ERK phosphorylation in astrocytes via S1P receptors. Neuropharmacology 2007, 52, 1210-1218. [CrossRef]

121. Segura-Ulate, I.; Yang, B.; Vargas-Medrano, J.; Perez, R.G. FTY720 (Fingolimod) reverses alpha-synuclein-induced downregulation of brain-derived neurotrophic factor mRNA in OLN-93 oligodendroglial cells. Neuropharmacology 2017, 117, 149-157. [CrossRef] [PubMed] 
122. Michell-Robinson, M.A.; Moore, C.S.; Healy, L.M.; Osso, L.A.; Zorko, N.; Grouza, V.; Touil, H.; Poliquin-Lasnier, L.; Trudelle, A.M.; Giacomini, P.S.; et al. Effects of fumarates on circulating and CNS myeloid cells in multiple sclerosis. Ann. Clin. Transl. Neurol. 2016, 3, 27-41. [CrossRef] [PubMed]

123. Fowler, J.H.; McQueen, J.; Holland, P.R.; Manso, Y.; Marangoni, M.; Scott, F.; Chisholm, E.; Scannevin, R.H.; Hardingham, G.E.; Horsburgh, K. Dimethyl fumarate improves white matter function following severe hypoperfusion: Involvement of microglia/macrophages and inflammatory mediators. J. Cereb Blood Flow Metab. 2018, 38, 1354-1370. [CrossRef] [PubMed]

124. Lin, R.; Cai, J.; Kostuk, E.W.; Rosenwasser, R.; Iacovitti, L. Fumarate modulates the immune/inflammatory response and rescues nerve cells and neurological function after stroke in rats. J. Neuroinflammation 2016, 13, 269. [CrossRef] [PubMed]

125. Liu, L.; Vollmer, M.K.; Ahmad, A.S.; Fernandez, V.M.; Kim, H.; Dore, S. Pretreatment with Korean red ginseng or dimethyl fumarate attenuates reactive gliosis and confers sustained neuroprotection against cerebral hypoxic-ischemic damage by an Nrf2-dependent mechanism. Free Radic. Biol. Med. 2019, 131, 98-114. [CrossRef]

126. Traub, J.; Traffehn, S.; Ochs, J.; Hausser-Kinzel, S.; Stephan, S.; Scannevin, R.; Bruck, W.; Metz, I.; Weber, M.S. Dimethyl fumarate impairs differentiated B cells and fosters central nervous system integrity in treatment of multiple sclerosis. Brain Pathol. 2019, 29, 640-657. [CrossRef]

127. Campolo, M.; Casili, G.; Biundo, F.; Crupi, R.; Cordaro, M.; Cuzzocrea, S.; Esposito, E. The Neuroprotective Effect of Dimethyl Fumarate in an MPTP-Mouse Model of Parkinson's Disease: Involvement of Reactive Oxygen Species/Nuclear Factor-kappaB/Nuclear Transcription Factor Related to NF-E2. Antioxid Redox. Signal 2017, 27, 453-471. [CrossRef]

128. Southwood, C.M.; Garshott, D.M.; Richardson, C.R.; Seraji-Bozorgzad, N.; Fribley, A.M.; Gow, A. Dimethyl fumarate ameliorates myoclonus stemming from protein misfolding in oligodendrocytes. J. Neurochem. 2017, 142, 103-117. [CrossRef]

129. Cordaro, M.; Casili, G.; Paterniti, I.; Cuzzocrea, S.; Esposito, E. Fumaric Acid Esters Attenuate Secondary Degeneration after Spinal Cord Injury. J. Neurotrauma. 2017, 34, 3027-3040. [CrossRef]

130. Iniaghe, L.O.; Krafft, P.R.; Klebe, D.W.; Omogbai, E.K.I.; Zhang, J.H.; Tang, J. Dimethyl fumarate confers neuroprotection by casein kinase 2 phosphorylation of Nrf2 in murine intracerebral hemorrhage. Neurobiol. Dis. 2015, 82, 349-358. [CrossRef]

131. Cuadrado, A.; Kugler, S.; Lastres-Becker, I. Pharmacological targeting of GSK-3 and NRF2 provides neuroprotection in a preclinical model of tauopathy. Redox Biol. 2018, 14, 522-534. [CrossRef] [PubMed]

132. Paraiso, H.C.; Kuo, P.C.; Curfman, E.T.; Moon, H.J.; Sweazey, R.D.; Yen, J.H.; Chang, F.L.; Yu, I.C. Dimethyl fumarate attenuates reactive microglia and long-term memory deficits following systemic immune challenge. J. Neuroinflammation 2018, 15, 100. [CrossRef] [PubMed]

133. Majkutewicz, I.; Kurowska, E.; Podlacha, M.; Myslinska, D.; Grembecka, B.; Rucinski, J.; Pierzynowska, K.; Wrona, D. Age-dependent effects of dimethyl fumarate on cognitive and neuropathological features in the streptozotocin-induced rat model of Alzheimer's disease. Brain Res. 2018, 1686, 19-33. [CrossRef] [PubMed]

134. Pagani, F.; Testi, C.; Grimaldi, A.; Corsi, G.; Cortese, B.; Basilico, B.; Baiocco, P.; De Panfilis, S.; Ragozzino, D.; Di Angelantonio, S. Dimethyl Fumarate Reduces Microglia Functional Response to Tissue Damage and Favors Brain Iron Homeostasis. Neuroscience 2019. [CrossRef]

135. Kronenberg, J.; Pars, K.; Brieskorn, M.; Prajeeth, C.K.; Heckers, S.; Schwenkenbecher, P.; Skripuletz, T.; Pul, R.; Pavlou, A.; Stangel, M. Fumaric Acids Directly Influence Gene Expression of Neuroprotective Factors in Rodent Microglia. Int. J. Mol. Sci. 2019, 20, 325. [CrossRef]

136. Booth, L.; Cruickshanks, N.; Tavallai, S.; Roberts, J.L.; Peery, M.; Poklepovic, A.; Dent, P. Regulation of dimethyl-fumarate toxicity by proteasome inhibitors. Cancer Biol. Ther. 2014, 15, 1646-1657. [CrossRef]

137. Parodi, B.; Rossi, S.; Morando, S.; Cordano, C.; Bragoni, A.; Motta, C.; Usai, C.; Wipke, B.T.; Scannevin, R.H.; Mancardi, G.L.; et al. Fumarates modulate microglia activation through a novel HCAR2 signaling pathway and rescue synaptic dysregulation in inflamed CNS. Acta. Neuropathol. 2015, 130, 279-295. [CrossRef]

138. Moharregh-Khiabani, D.; Blank, A.; Skripuletz, T.; Miller, E.; Kotsiari, A.; Gudi, V.; Stangel, M. Effects of fumaric acids on cuprizone induced central nervous system de- and remyelination in the mouse. PLoS ONE 2010, 5, e11769. [CrossRef] [PubMed] 
139. Reick, C.; Ellrichmann, G.; Thone, J.; Scannevin, R.H.; Saft, C.; Linker, R.A.; Gold, R. Neuroprotective dimethyl fumarate synergizes with immunomodulatory interferon beta to provide enhanced axon protection in autoimmune neuroinflammation. Exp. Neurol. 2014, 257, 50-56. [CrossRef]

140. Zhao, X.; Sun, G.; Zhang, J.; Ting, S.M.; Gonzales, N.; Aronowski, J. Dimethyl Fumarate Protects Brain From Damage Produced by Intracerebral Hemorrhage by Mechanism Involving Nrf2. Stroke 2015, 46, 1923-1928. [CrossRef]

141. Wierinckx, A.; Breve, J.; Mercier, D.; Schultzberg, M.; Drukarch, B.; Van Dam, A.M. Detoxication enzyme inducers modify cytokine production in rat mixed glial cells. J. Neuroimmunol. 2005, 166, 132-143. [CrossRef] [PubMed]

142. Wilms, H.; Sievers, J.; Rickert, U.; Rostami-Yazdi, M.; Mrowietz, U.; Lucius, R. Dimethylfumarate inhibits microglial and astrocytic inflammation by suppressing the synthesis of nitric oxide, IL-1beta, TNF-alpha and IL-6 in an in-vitro model of brain inflammation. J. Neuroinflammation 2010, 7, 30. [CrossRef] [PubMed]

143. Peng, H.; Li, H.; Sheehy, A.; Cullen, P.; Allaire, N.; Scannevin, R.H. Dimethyl fumarate alters microglia phenotype and protects neurons against proinflammatory toxic microenvironments. J. Neuroimmunol. 2016, 299, 35-44. [CrossRef] [PubMed]

144. Foresti, R.; Bains, S.K.; Pitchumony, T.S.; de Castro Bras, L.E.; Drago, F.; Dubois-Rande, J.L.; Bucolo, C.; Motterlini, R. Small molecule activators of the Nrf2-HO-1 antioxidant axis modulate heme metabolism and inflammation in BV2 microglia cells. Pharmacol. Res. 2013, 76, 132-148. [CrossRef] [PubMed]

145. Graber, D.J.; Hickey, W.F.; Stommel, E.W.; Harris, B.T. Anti-inflammatory efficacy of dexamethasone and Nrf2 activators in the CNS using brain slices as a model of acute injury. J. Neuroimmune Pharmacol. 2012, 7, 266-278. [CrossRef]

146. Ambrosius, B.; Faissner, S.; Guse, K.; von Lehe, M.; Grunwald, T.; Gold, R.; Grewe, B.; Chan, A. Teriflunomide and monomethylfumarate target HIV-induced neuroinflammation and neurotoxicity. J. Neuroinflammation 2017, 14, 51. [CrossRef]

147. Pars, K.; Gingele, M.; Kronenberg, J.; Prajeeth, C.K.; Skripuletz, T.; Pul, R.; Jacobs, R.; Gudi, V.; Stangel, M. Fumaric Acids Do Not Directly Influence Gene Expression of Neuroprotective Factors in Highly Purified Rodent Astrocytes. Brain Sci. 2019, 9, 241. [CrossRef]

148. Galloway, D.A.; Williams, J.B.; Moore, C.S. Effects of fumarates on inflammatory human astrocyte responses and oligodendrocyte differentiation. Ann. Clin. Transl. Neurol. 2017, 4, 381-391. [CrossRef]

149. Kunze, R.; Urrutia, A.; Hoffmann, A.; Liu, H.; Helluy, X.; Pham, M.; Reischl, S.; Korff, T.; Marti, H.H. Dimethyl fumarate attenuates cerebral edema formation by protecting the blood-brain barrier integrity. Exp. Neurol. 2015, 266, 99-111. [CrossRef]

150. Kalinin, S.; Polak, P.E.; Lin, S.X.; Braun, D.; Guizzetti, M.; Zhang, X.; Rubinstein, I.; Feinstein, D.L. Dimethyl fumarate regulates histone deacetylase expression in astrocytes. J. Neuroimmunol. 2013, 263, 13-19. [CrossRef]

151. Murphy, T.H.; Yu, J.; Ng, R.; Johnson, D.A.; Shen, H.; Honey, C.R.; Johnson, J.A. Preferential expression of antioxidant response element mediated gene expression in astrocytes. J. Neurochem. 2001, 76, 1670-1678. [CrossRef] [PubMed]

152. Gill, A.J.; Kovacsics, C.E.; Cross, S.A.; Vance, P.J.; Kolson, L.L.; Jordan-Sciutto, K.L.; Gelman, B.B.; Kolson, D.L. Heme oxygenase-1 deficiency accompanies neuropathogenesis of HIV-associated neurocognitive disorders. J. Clin. Investig. 2014, 124, 4459-4472. [CrossRef] [PubMed]

153. Bombeiro, A.L.; Toledo Nunes Pereira, B.; Pires Bonfanti, A.; de Oliveira, A.L.R. Immunomodulation by dimethyl fumarate treatment improves mouse sciatic nerve regeneration. Brain Res. Bull 2020. [CrossRef] [PubMed]

154. Chen, H.; Assmann, J.C.; Krenz, A.; Rahman, M.; Grimm, M.; Karsten, C.M.; Kohl, J.; Offermanns, S.; Wettschureck, N.; Schwaninger, M. Hydroxycarboxylic acid receptor 2 mediates dimethyl fumarate's protective effect in EAE. J. Clin. Investig. 2014, 124, 2188-2192. [CrossRef]

155. Kumar, P.; Sharma, G.; Gupta, V.; Kaur, R.; Thakur, K.; Malik, R.; Kumar, A.; Kaushal, N.; Raza, K. Preclinical Explorative Assessment of Dimethyl Fumarate-Based Biocompatible Nanolipoidal Carriers for the Management of Multiple Sclerosis. ACS Chem. Neurosci. 2018, 9, 1152-1158. [CrossRef]

156. Huang, H.; Taraboletti, A.; Shriver, L.P. Dimethyl fumarate modulates antioxidant and lipid metabolism in oligodendrocytes. Redox Biol. 2015, 5, 169-175. [CrossRef]

157. Weber, M.S.; Hohlfeld, R.; Zamvil, S.S. Mechanism of action of glatiramer acetate in treatment of multiple sclerosis. Neurotherapeutics 2007, 4, 647-653. [CrossRef] 
158. Lalive, P.H.; Neuhaus, O.; Benkhoucha, M.; Burger, D.; Hohlfeld, R.; Zamvil, S.S.; Weber, M.S. Glatiramer acetate in the treatment of multiple sclerosis: Emerging concepts regarding its mechanism of action. CNS Drugs 2011, 25, 401-414. [CrossRef]

159. Yong, V.W. Differential mechanisms of action of interferon-beta and glatiramer aetate in MS. Neurology 2002, 59, 802-808. [CrossRef]

160. Maier, K.; Kuhnert, A.V.; Taheri, N.; Sattler, M.B.; Storch, M.K.; Williams, S.K.; Bahr, M.; Diem, R. Effects of glatiramer acetate and interferon-beta on neurodegeneration in a model of multiple sclerosis: A comparative study. Am. J. Pathol. 2006, 169, 1353-1364. [CrossRef]

161. Gilli, F.; Navone, N.D.; Perga, S.; Marnetto, F.; Caldano, M.; Capobianco, M.; Pulizzi, A.; Malucchi, S.; Bertolotto, A. Loss of braking signals during inflammation: A factor affecting the development and disease course of multiple sclerosis. Arch. Neurol. 2011, 68, 879-888. [CrossRef] [PubMed]

162. He, F.; Zou, J.T.; Zhou, Q.F.; Niu, D.L.; Jia, W.H. Glatiramer acetate reverses cognitive deficits from cranial-irradiated rat by inducing hippocampal neurogenesis. J. Neuroimmunol. 2014, 271, 1-7. [CrossRef] [PubMed]

163. Leger, T.; Grist, J.; D'Acquisto, F.; Clark, A.K.; Malcangio, M. Glatiramer acetate attenuates neuropathic allodynia through modulation of adaptive immune cells. J. Neuroimmunol. 2011, 234, 19-26. [CrossRef] [PubMed]

164. Aharoni, R.; Eilam, R.; Stock, A.; Vainshtein, A.; Shezen, E.; Gal, H.; Friedman, N.; Arnon, R. Glatiramer acetate reduces Th-17 inflammation and induces regulatory T-cells in the CNS of mice with relapsing-remitting or chronic EAE. J. Neuroimmunol. 2010, 225, 100-111. [CrossRef] [PubMed]

165. Reichert, F.; Rotshenker, S. Galectin-3/MAC-2 in experimental allergic encephalomyelitis. Exp. Neurol. 1999, 160, 508-514. [CrossRef] [PubMed]

166. Aharoni, R.; Arnon, R.; Eilam, R. Neurogenesis and neuroprotection induced by peripheral immunomodulatory treatment of experimental autoimmune encephalomyelitis. J. Neurosci. 2005, 25, 8217-8228. [CrossRef] [PubMed]

167. Butovsky, O.; Koronyo-Hamaoui, M.; Kunis, G.; Ophir, E.; Landa, G.; Cohen, H.; Schwartz, M. Glatiramer acetate fights against Alzheimer's disease by inducing dendritic-like microglia expressing insulin-like growth factor 1. Proc. Natl. Acad Sci. USA 2006, 103, 11784-11789. [CrossRef]

168. Chabot, S.; Yong, F.P.; Le, D.M.; Metz, L.M.; Myles, T.; Yong, V.W. Cytokine production in T lymphocyte-microglia interaction is attenuated by glatiramer acetate: A mechanism for therapeutic efficacy in multiple sclerosis. Mult. Scler. 2002, 8, 299-306. [CrossRef]

169. Gentile, A.; Rossi, S.; Studer, V.; Motta, C.; De Chiara, V.; Musella, A.; Sepman, H.; Fresegna, D.; Musumeci, G.; Grasselli, G.; et al. Glatiramer acetate protects against inflammatory synaptopathy in experimental autoimmune encephalomyelitis. J. Neuroimmune. Pharmacol. 2013, 8, 651-663. [CrossRef]

170. Rosato Siri, M.V.; Badaracco, M.E.; Pasquini, J.M. Glatiramer promotes oligodendroglial cell maturation in a cuprizone-induced demyelination model. Neurochem. Int. 2013, 63, 10-24. [CrossRef]

171. Pul, R.; Moharregh-Khiabani, D.; Skuljec, J.; Skripuletz, T.; Garde, N.; Voss, E.V.; Stangel, M. Glatiramer acetate modulates TNF-alpha and IL-10 secretion in microglia and promotes their phagocytic activity. J. Neuroimmune. Pharmacol. 2011, 6, 381-388. [CrossRef] [PubMed]

172. Nau, R.; Ribes, S.; Djukic, M.; Eiffert, H. Strategies to increase the activity of microglia as efficient protectors of the brain against infections. Front Cell Neurosci. 2014, 8, 138. [CrossRef] [PubMed]

173. Chan, A.; Papadimitriou, C.; Graf, W.; Toyka, K.V.; Gold, R. Effects of polyclonal immunoglobulins and other immunomodulatory agents on microglial phagocytosis of apoptotic inflammatory T-cells. J. Neuroimmunol. 2003, 135, 161-165. [CrossRef]

174. Aharoni, R.; Kayhan, B.; Eilam, R.; Sela, M.; Arnon, R. Glatiramer acetate-specific T cells in the brain express T helper 2/3 cytokines and brain-derived neurotrophic factor in situ. Proc. Natl. Acad Sci. USA 2003, 100, 14157-14162. [CrossRef] [PubMed]

175. Evangelidou, M.; Karamita, M.; Vamvakas, S.S.; Szymkowski, D.E.; Probert, L. Altered expression of oligodendrocyte and neuronal marker genes predicts the clinical onset of autoimmune encephalomyelitis and indicates the effectiveness of multiple sclerosis-directed therapeutics. J. Immunol. 2014, 192, 4122-4133. [CrossRef] [PubMed] 
176. Aharoni, R.; Schottlender, N.; Bar-Lev, D.D.; Eilam, R.; Sela, M.; Tsoory, M.; Arnon, R. Cognitive impairment in an animal model of multiple sclerosis and its amelioration by glatiramer acetate. Sci. Rep. 2019, 9, 4140. [CrossRef] [PubMed]

177. Reick, C.; Ellrichmann, G.; Tsai, T.; Lee, D.H.; Wiese, S.; Gold, R.; Saft, C.; Linker, R.A. Expression of brain-derived neurotrophic factor in astrocytes - Beneficial effects of glatiramer acetate in the R6/2 and YAC128 mouse models of Huntington's disease. Exp. Neurol. 2016, 285, 12-23. [CrossRef]

178. Corey-Bloom, J.; Aikin, A.M.; Gutierrez, A.M.; Nadhem, J.S.; Howell, T.L.; Thomas, E.A. Beneficial effects of glatiramer acetate in Huntington's disease mouse models: Evidence for BDNF-elevating and immunomodulatory mechanisms. Brain Res. 2017, 1673, 102-110. [CrossRef]

179. Moore, S.; Khalaj, A.J.; Patel, R.; Yoon, J.; Ichwan, D.; Hayardeny, L.; Tiwari-Woodruff, S.K. Restoration of axon conduction and motor deficits by therapeutic treatment with glatiramer acetate. J. Neurosci. Res. 2014, 92, 1621-1636. [CrossRef]

180. Gilgun-Sherki, Y.; Panet, H.; Holdengreber, V.; Mosberg-Galili, R.; Offen, D. Axonal damage is reduced following glatiramer acetate treatment in $\mathrm{C} 57 / \mathrm{bl}$ mice with chronic-induced experimental autoimmune encephalomyelitis. Neurosci. Res. 2003, 47, 201-207. [CrossRef]

181. Lee, D.H.; Geyer, E.; Flach, A.C.; Jung, K.; Gold, R.; Flugel, A.; Linker, R.A.; Luhder, F. Central nervous system rather than immune cell-derived BDNF mediates axonal protective effects early in autoimmune demyelination. Acta. Neuropathol. 2012, 123, 247-258. [CrossRef] [PubMed]

182. Schori, H.; Robenshtok, E.; Schwartz, M.; Hourvitz, A. Post-intoxication vaccination for protection of neurons against the toxicity of nerve agents. Toxicol. Sci. 2005, 87, 163-168. [CrossRef] [PubMed]

183. Aharoni, R.; Herschkovitz, A.; Eilam, R.; Blumberg-Hazan, M.; Sela, M.; Bruck, W.; Arnon, R. Demyelination arrest and remyelination induced by glatiramer acetate treatment of experimental autoimmune encephalomyelitis. Proc. Natl. Acad. Sci. USA 2008, 105, 11358-11363. [CrossRef] [PubMed]

184. Khan, O.; Shen, Y.; Bao, F.; Caon, C.; Tselis, A.; Latif, Z.; Zak, I. Long-term study of brain 1H-MRS study in multiple sclerosis: Effect of glatiramer acetate therapy on axonal metabolic function and feasibility of long-Term H-MRS monitoring in multiple sclerosis. J. Neuroimaging 2008, 18, 314-319. [CrossRef]

185. Wiebenga, O.T.; Klauser, A.M.; Schoonheim, M.M.; Nagtegaal, G.J.; Steenwijk, M.D.; van Rossum, J.A.; Polman, C.H.; Barkhof, F.; Pouwels, P.J.; Geurts, J.J. Enhanced axonal metabolism during early natalizumab treatment in relapsing-remitting multiple sclerosis. AJNR Am. J. Neuroradiol. 2015, 36, 1116-1123. [CrossRef]

186. Skihar, V.; Silva, C.; Chojnacki, A.; Doring, A.; Stallcup, W.B.; Weiss, S.; Yong, V.W. Promoting oligodendrogenesis and myelin repair using the multiple sclerosis medication glatiramer acetate. Proc. Natl. Acad Sci. USA 2009, 106, 17992-17997. [CrossRef]

187. Song, F.; Bandara, M.; Deol, H.; Loeb, J.A.; Benjamins, J.; Lisak, R.P. Complexity of trophic factor signaling in experimental autoimmune encephalomyelitis: Differential expression of neurotrophic and gliotrophic factors. J. Neuroimmunol. 2013, 262, 11-18. [CrossRef]

188. From, R.; Eilam, R.; Bar-Lev, D.D.; Levin-Zaidman, S.; Tsoory, M.; LoPresti, P.; Sela, M.; Arnon, R.; Aharoni, R. Oligodendrogenesis and myelinogenesis during postnatal development effect of glatiramer acetate. Glia 2014, 62, 649-665. [CrossRef]

189. Zhang, Y.; Jalili, F.; Ouamara, N.; Zameer, A.; Cosentino, G.; Mayne, M.; Hayardeny, L.; Antel, J.P.; Bar-Or, A.; John, G.R. Glatiramer acetate-reactive T lymphocytes regulate oligodendrocyte progenitor cell number in vitro: Role of IGF-2. J. Neuroimmunol. 2010, 227, 71-79. [CrossRef]

190. Zula, J.A.; Green, H.C.; Ransohoff, R.M.; Rudick, R.A.; Stark, G.R.; van Boxel-Dezaire, A.H. The role of cell type-specific responses in IFN-beta therapy of multiple sclerosis. Proc. Natl. Acad Sci. USA 2011, 108, 19689-19694. [CrossRef]

191. Lopez de Padilla, C.M.; Niewold, T.B. The type I interferons: Basic concepts and clinical relevance in immune-mediated inflammatory diseases. Gene 2016, 576, 14-21. [CrossRef] [PubMed]

192. McDonough, A.; Lee, R.V.; Weinstein, J.R. Microglial Interferon Signaling and White Matter. Neurochem. Res. 2017, 42, 2625-2638. [CrossRef] [PubMed]

193. Trebst, C.; Heine, S.; Lienenklaus, S.; Lindner, M.; Baumgartner, W.; Weiss, S.; Stangel, M. Lack of interferon-beta leads to accelerated remyelination in a toxic model of central nervous system demyelination. Acta. Neuropathol. 2007, 114, 587-596. [CrossRef] [PubMed] 
194. Main, B.S.; Zhang, M.; Brody, K.M.; Ayton, S.; Frugier, T.; Steer, D.; Finkelstein, D.; Crack, P.J.; Taylor, J.M. Type-1 interferons contribute to the neuroinflammatory response and disease progression of the MPTP mouse model of Parkinson's disease. Glia 2016, 64, 1590-1604. [CrossRef] [PubMed]

195. Minter, M.R.; Moore, Z.; Zhang, M.; Brody, K.M.; Jones, N.C.; Shultz, S.R.; Taylor, J.M.; Crack, P.J. Deletion of the type-1 interferon receptor in APPSWE/PS1DeltaE9 mice preserves cognitive function and alters glial phenotype. Acta. Neuropathol. Commun. 2016, 4, 72. [CrossRef]

196. Choi, B.Y.; Sim, C.K.; Cho, Y.S.; Sohn, M.; Kim, Y.J.; Lee, M.S.; Suh, S.W. 2'-5' oligoadenylate synthetase-like 1 (OASL1) deficiency suppresses central nervous system damage in a murine MOG-induced multiple sclerosis model. Neurosci. Lett. 2016, 628, 78-84. [CrossRef]

197. Isaksson, M.; Ardesjo, B.; Ronnblom, L.; Kampe, O.; Lassmann, H.; Eloranta, M.L.; Lobell, A. Plasmacytoid DC promote priming of autoimmune Th17 cells and EAE. Eur. J. Immunol. 2009, 39, 2925-2935. [CrossRef]

198. Costello, D.A.; Lynch, M.A. Toll-like receptor 3 activation modulates hippocampal network excitability, via glial production of interferon-beta. Hippocampus 2013, 23, 696-707. [CrossRef]

199. Kasper, L.H.; Reder, A.T. Immunomodulatory activity of interferon-beta. Ann. Clin. Transl. Neurol. 2014, 1, 622-631. [CrossRef]

200. Cohen, B.; Novick, D.; Barak, S.; Rubinstein, M. Ligand-induced association of the type I interferon receptor components. Mol. Cell Biol. 1995, 15, 4208-4214. [CrossRef]

201. Levin, D.; Harari, D.; Schreiber, G. Stochastic receptor expression determines cell fate upon interferon treatment. Mol. Cell Biol. 2011, 31, 3252-3266. [CrossRef] [PubMed]

202. Esen, N.; Rainey-Barger, E.K.; Huber, A.K.; Blakely, P.K.; Irani, D.N. Type-I interferons suppress microglial production of the lymphoid chemokine, CXCL13. Glia 2014, 62, 1452-1462. [CrossRef] [PubMed]

203. Konnecke, H.; Bechmann, I. The role of microglia and matrix metalloproteinases involvement in neuroinflammation and gliomas. Clin. Dev. Immunol. 2013, 2013, 914104. [CrossRef] [PubMed]

204. Liuzzi, G.M.; Latronico, T.; Fasano, A.; Carlone, G.; Riccio, P. Interferon-beta inhibits the expression of metalloproteinases in rat glial cell cultures: Implications for multiple sclerosis pathogenesis and treatment. Mult. Scler. 2004, 10, 290-297. [CrossRef] [PubMed]

205. Luckoff, A.; Caramoy, A.; Scholz, R.; Prinz, M.; Kalinke, U.; Langmann, T. Interferon-beta signaling in retinal mononuclear phagocytes attenuates pathological neovascularization. EMBO Mol. Med. 2016, 8, 670-678. [CrossRef] [PubMed]

206. Li, P.; Zhao, G.; Ding, Y.; Wang, T.; Flores, J.; Ocak, U.; Wu, P.; Zhang, T.; Mo, J.; Zhang, J.H.; et al. Rh-IFN-alpha attenuates neuroinflammation and improves neurological function by inhibiting NF-kappaB through JAK1-STAT1/TRAF3 pathway in an experimental GMH rat model. Brain Behav. Immun. 2019, 79, 174-185. [CrossRef]

207. Sattler, M.B.; Demmer, I.; Williams, S.K.; Maier, K.; Merkler, D.; Gadjanski, I.; Stadelmann, C.; Bahr, M.; Diem, R. Effects of interferon-beta-1a on neuronal survival under autoimmune inflammatory conditions. Exp. Neurol. 2006, 201, 172-181. [CrossRef]

208. MacMillan, E.L.; Schubert, J.J.; Vavasour, I.M.; Tam, R.; Rauscher, A.; Taylor, C.; White, R.; Garren, H.; Clayton, D.; Levesque, V.; et al. Magnetic resonance spectroscopy evidence for declining gliosis in MS patients treated with ocrelizumab versus interferon beta-1a. Mult. Scler. J. Exp. Transl. Clin. 2019, 5, 2055217319879952. [CrossRef]

209. Roy, E.R.; Wang, B.; Wan, Y.W.; Chiu, G.; Cole, A.; Yin, Z.; Propson, N.E.; Xu, Y.; Jankowsky, J.L.; Liu, Z.; et al. Type I interferon response drives neuroinflammation and synapse loss in Alzheimer disease. J. Clin. Investig. 2020. [CrossRef]

210. GuhaSarkar, D.; Neiswender, J.; Su, Q.; Gao, G.; Sena-Esteves, M. Intracranial AAV-IFN-beta gene therapy eliminates invasive xenograft glioblastoma and improves survival in orthotopic syngeneic murine model. Mol. Oncol. 2017, 11, 180-193. [CrossRef]

211. Ben-Yehuda, H.; Matcovitch-Natan, O.; Kertser, A.; Spinrad, A.; Prinz, M.; Amit, I.; Schwartz, M. Maternal Type-I interferon signaling adversely affects the microglia and the behavior of the offspring accompanied by increased sensitivity to stress. Mol. Psychiatry 2019. [CrossRef] [PubMed]

212. Hall, G.L.; Wing, M.G.; Compston, D.A.S.; Scolding, N.J. $\beta$-interferon regulates the immunomodulatory activity of neonatal rodent microglia. J. Neuroimmunol. 1997, 72, 11-19. [CrossRef] 
213. Sen, T.; Saha, P.; Gupta, R.; Foley, L.M.; Jiang, T.; Abakumova, O.S.; Hitchens, T.K.; Sen, N. Aberrant ER Stress Induced Neuronal-IFNbeta Elicits White Matter Injury Due to Microglial Activation and T-Cell Infiltration after TBI. J. Neurosci. 2020, 40, 424-446. [CrossRef] [PubMed]

214. Wachholz, S.; Esslinger, M.; Plumper, J.; Manitz, M.P.; Juckel, G.; Friebe, A. Microglia activation is associated with IFN-alpha induced depressive-like behavior. Brain Behav. Immun. 2016, 55, 105-113. [CrossRef]

215. Nakamichi, K.; Saiki, M.; Kitani, H.; Kuboyama, Y.; Morimoto, K.; Takayama-Ito, M.; Kurane, I. Suppressive effect of simvastatin on interferon-beta-induced expression of CC chemokine ligand 5 in microglia. Neurosci. Lett. 2006, 407, 205-210. [CrossRef]

216. Jin, S.; Kawanokuchi, J.; Mizuno, T.; Wang, J.; Sonobe, Y.; Takeuchi, H.; Suzumura, A. Interferon-beta is neuroprotective against the toxicity induced by activated microglia. Brain Res. 2007, 1179, 140-146. [CrossRef]

217. Li, W.; Viengkhou, B.; Denyer, G.; West, P.K.; Campbell, I.L.; Hofer, M.J. Microglia have a more extensive and divergent response to interferon-alpha compared with astrocytes. Glia 2018, 66, 2058-2078. [CrossRef]

218. Khatun, M.R.; Arifuzzaman, S. Selected TLR7/8 agonist and type I interferon (IFN-alpha) cooperatively redefine the microglia transcriptome. Inflammopharmacology 2019. [CrossRef]

219. Cox, D.J.; Field, R.H.; Williams, D.G.; Baran, M.; Bowie, A.G.; Cunningham, C.; Dunne, A. DNA sensors are expressed in astrocytes and microglia in vitro and are upregulated during gliosis in neurodegenerative disease. Glia 2015, 63, 812-825. [CrossRef]

220. Mastronardi, F.G.; Min, W.; Wang, H.; Winer, S.; Dosch, M.; Boggs, J.M.; Moscarello, M.A. Attenuation of experimental autoimmune encephalomyelitis and nonimmune demyelination by IFN-beta plus vitamin B12: Treatment to modify notch-1/sonic hedgehog balance. J. Immunol. 2004, 172, 6418-6426. [CrossRef]

221. Chhatbar, C.; Detje, C.N.; Grabski, E.; Borst, K.; Spanier, J.; Ghita, L.; Elliott, D.A.; Jordao, M.J.C.; Mueller, N.; Sutton, J.; et al. Type I Interferon Receptor Signaling of Neurons and Astrocytes Regulates Microglia Activation during Viral Encephalitis. Cell Rep. 2018, 25, 118-129. [CrossRef] [PubMed]

222. Rothhammer, V.; Mascanfroni, I.D.; Bunse, L.; Takenaka, M.C.; Kenison, J.E.; Mayo, L.; Chao, C.C.; Patel, B.; Yan, R.; Blain, M.; et al. Type I interferons and microbial metabolites of tryptophan modulate astrocyte activity and central nervous system inflammation via the aryl hydrocarbon receptor. Nat. Med. 2016, 22, 586-597. [CrossRef] [PubMed]

223. Malik, O.; Compston, D.A.S.; Scolding, N.J. Interferon-beta inhibits mitogen induced astrocyte proliferation in vitro. J. Neuroimmunol. 1998, 86, 155-162. [CrossRef]

224. Garrison, J.I.; Berens, M.E.; Shapiro, J.R.; Treasurywala, S.; Floyd-Smith, G. Interferon-beta inhibits proliferation and progression through $\mathrm{S}$ phase of the cell cycle in five glioma cell lines. J. Neurooncol. 1996, 30, 213-223. [CrossRef] [PubMed]

225. Guthikonda, P.; Baker, J.; Mattson, D.H. Interferon-beta-1-b (IFN-B) decreases induced nitric oxide (NO) production by a human astrocytoma cell line. J. Neuroimmunol. 1998, 82, 133-139. [CrossRef]

226. Latronico, T.; Brana, M.T.; Gramegna, P.; Fasano, A.; Di Bari, G.; Liuzzi, G.M. Inhibition of myelin-cleaving poteolytic activities by interferon-beta in rat astrocyte cultures. Comparative analysis between gelatinases and calpain-II. PLoS ONE 2013, 8, e49656. [CrossRef]

227. Muller, M.; Frese, A.; Nassenstein, I.; Hoppen, M.; Marziniak, M.; Ringelstein, E.B.; Kim, K.S.; Schabitz, W.R.; Kraus, J. Serum from interferon-beta-1b-treated patients with early multiple sclerosis stabilizes the blood-brain barrier in vitro. Mult. Scler. 2012, 18, 236-239. [CrossRef]

228. Kraus, J.; Ling, A.K.; Hamm, S.; Voigt, K.; Oschmann, P.; Engelhardt, B. Interferon-beta stabilizes barrier characteristics of brain endothelial cells in vitro. Ann. Neurol. 2004, 56, 192-205. [CrossRef]

229. Vergara, D.; Martignago, R.; Bonsegna, S.; De Nuccio, F.; Santino, A.; Nicolardi, G.; Maffia, M. IFN-beta reverses the lipopolysaccharide-induced proteome modifications in treated astrocytes. J. Neuroimmunol. 2010, 221, 115-120. [CrossRef]

230. Clarke, P.; Zhuang, Y.; Berens, H.M.; Leser, J.S.; Tyler, K.L. Interferon Beta Contributes to Astrocyte Activation in the Brain following Reovirus Infection. J. Virol. 2019, 93. [CrossRef]

231. Inacio, R.F.; Zanon, R.G.; Castro, M.V.; Souza, H.M.; Bajgelman, M.C.; Verinaud, L.; Oliveira, A.L. Astroglioma conditioned medium increases synaptic elimination and correlates with major histocompatibility complex of class I (MHC I) upregulation in PC12Cells. Neurosci. Lett. 2016, 634, 160-167. [CrossRef] [PubMed]

232. Khorooshi, R.; Owens, T. Injury-induced type I IFN signaling regulates inflammatory responses in the central nervous system. J. Immunol. 2010, 185, 1258-1264. [CrossRef] [PubMed] 
233. Rizzo, M.D.; Crawford, R.B.; Bach, A.; Sermet, S.; Amalfitano, A.; Kaminski, N.E. Imiquimod and interferon-alpha augment monocyte-mediated astrocyte secretion of MCP-1, IL-6 and IP-10 in a human co-culture system. J. Neuroimmunol. 2019, 333, 576969. [CrossRef] [PubMed]

234. Barca, O.; Costoya, J.A.; Senaris, R.M.; Arce, V.M. Interferon-beta protects astrocytes against tumour necrosis factor-induced apoptosis via activation of p38 mitogen-activated protein kinase. Exp. Cell Res. 2008, 314, 2231-2237. [CrossRef] [PubMed]

235. Barca, O.; Seoane, M.; Ferre, S.; Prieto, J.M.; Lema, M.; Senaris, R.; Arce, V.M. Mechanisms of interferon-beta-induced survival in fetal and neonatal primary astrocytes. Neuroimmunomodulation 2007, 14, 39-45. [CrossRef] [PubMed]

236. Barca, O.; Devesa-Peleteiro, P.; Seoane, M.; Senaris, R.M.; Arce, V.M. Bimodal effect of interferon-beta on astrocyte proliferation and survival: Importance of nuclear factor-kappaB. J. Neuroimmunol. 2010, 226, 73-80. [CrossRef]

237. Barca, O. Interferon beta promotes survival in primary astrocytes through phosphatidylinositol 3-kinase. J. Neuroimmunol. 2003, 139, 155-159. [CrossRef]

238. Parry, A.; Corkill, R.; Blamire, A.M.; Palace, J.; Narayanan, S.; Arnold, D.; Styles, P.; Matthews, P.M. Beta-Interferon treatment does not always slow the progression of axonal injury in multiple sclerosis. J. Neurol. 2003, 250, 171-178. [CrossRef]

239. Takeuchi, C.; Ota, K.; Ono, Y.; Iwata, M. Interferon Beta-1b may reverse axonal dysfunction in multiple sclerosis. Neuroradiol. J. 2007, 20, 531-540. [CrossRef]

240. Narayanan, S.; De Stefano, N.; Francis, G.S.; Arnaoutelis, R.; Caramanos, Z.; Collins, D.L.; Pelletier, D.; Arnason, B.G.W.; Antel, J.P.; Arnold, D.L. Axonal metabolic recovery in multiple sclerosis patients treated with interferon beta-1b. J. Neurol. 2001, 248, 979-986. [CrossRef]

241. Valeria, R.; Luisa, S.; Adele, M.; Stefania, B.; Fabio, T.; Nicoletta, B.; Carmine, P.M.; Silvia, A. Changes in the NMR Metabolic Profile of Live Human Neuron-Like SH-SY5Y Cells Exposed to Interferon-alpha2. J. Neuroimmune. Pharmacol. 2016, 11, 142-152. [CrossRef]

242. Low-Calle, A.M.; Prada-Arismendy, J.; Castellanos, J.E. Study of interferon-beta antiviral activity against Herpes simplex virus type 1 in neuron-enriched trigeminal ganglia cultures. Virus Res. 2014, 180, 49-58. [CrossRef] [PubMed]

243. Winkler, C.W.; Woods, T.A.; Groveman, B.R.; Carmody, A.B.; Speranza, E.E.; Martens, C.A.; Best, S.M.; Haigh, C.L.; Peterson, K.E. Neuronal maturation reduces the type I IFN response to orthobunyavirus infection and leads to increased apoptosis of human neurons. J. Neuroinflammation 2019, 16, 229. [CrossRef] [PubMed]

244. Kreit, M.; Paul, S.; Knoops, L.; De Cock, A.; Sorgeloos, F.; Michiels, T. Inefficient type I interferon-mediated antiviral protection of primary mouse neurons is associated with the lack of apolipoprotein 19 expression. J. Virol. 2014, 88, 3874-3884. [CrossRef] [PubMed]

245. Nakashima, T.; Hori, T.; Kuriyama, K.; Kiyohara, T. Naloxone blocks the interferon- $\alpha$ induced changes in hypothalamic neuronal activity. Neurosci. Lett. 1987, 82, 332-336. [CrossRef]

246. Inacio, R.F.; Zanon, R.G.; Verinaud, L.; de Oliveira, A.L. Interferon beta modulates major histocompatibility complex class I (MHC I) and CD3-zeta expression in PC12 cells. Neurosci. Lett. 2012, 513, 223-228. [CrossRef]

247. Lafaille, F.G.; Harschnitz, O.; Lee, Y.S.; Zhang, P.; Hasek, M.L.; Kerner, G.; Itan, Y.; Ewaleifoh, O.; Rapaport, F.; Carlile, T.M.; et al. Human SNORA31 variations impair cortical neuron-intrinsic immunity to HSV-1 and underlie herpes simplex encephalitis. Nat. Med. 2019, 25, 1873-1884. [CrossRef] [PubMed]

248. Dumitrascu, O.M.; Mott, K.R.; Ghiasi, H. A comparative study of experimental mouse models of central nervous system demyelination. Gene. Ther. 2014, 21, 599-608. [CrossRef]

249. Kotsiari, A.; Voss, E.V.; Pul, R.; Skripuletz, T.; Ragancokova, D.; Trebst, C.; Stangel, M. Interferon-beta treatment normalises the inhibitory effect of serum from multiple sclerosis patients on oligodendrocyte progenitor proliferation. Neurosci. Lett. 2010, 485, 107-111. [CrossRef]

250. Heine, S.; Ebnet, J.; Maysami, S.; Stangel, M. Effects of interferon-beta on oligodendroglial cells. J. Neuroimmunol. 2006, 177, 173-180. [CrossRef]

251. Penton-Rol, G.; Lagumersindez-Denis, N.; Muzio, L.; Bergami, A.; Furlan, R.; Fernandez-Masso, J.R.; Nazabal-Galvez, M.; Llopiz-Arzuaga, A.; Herrera-Rolo, T.; Veliz-Rodriguez, T.; et al. Comparative Neuroregenerative Effects of C-Phycocyanin and IFN-Beta in a Model of Multiple Sclerosis in Mice. J. Neuroimmune. Pharmacol. 2016, 11, 153-167. [CrossRef] [PubMed] 
252. Miyamoto, N.; Maki, T.; Pham, L.D.; Hayakawa, K.; Seo, J.H.; Mandeville, E.T.; Mandeville, J.B.; Kim, K.W.; Lo, E.H.; Arai, K. Oxidative stress interferes with white matter renewal after prolonged cerebral hypoperfusion in mice. Stroke 2013, 44, 3516-3521. [CrossRef] [PubMed]

253. Bar-Or, A.; Pachner, A.; Menguy-Vacheron, F.; Kaplan, J.; Wiendl, H. Teriflunomide and its mechanism of action in multiple sclerosis. Drugs 2014, 74, 659-674. [CrossRef] [PubMed]

254. Lu, Z.; Zhang, D.; Cui, K.; Fu, X.; Man, J.; Lu, H.; Yu, L.; Gao, Y.; Liu, X.; Liao, L.; et al. Neuroprotective Action of Teriflunomide in a Mouse Model of Transient Middle Cerebral Artery Occlusion. Neuroscience 2020, 428, 228-241. [CrossRef] [PubMed]

255. Rzagalinski, I.; Hainz, N.; Meier, C.; Tschernig, T.; Volmer, D.A. Spatial and molecular changes of mouse brain metabolism in response to immunomodulatory treatment with teriflunomide as visualized by MALDI-MSI. Anal. Bioanal. Chem. 2019, 411, 353-365. [CrossRef]

256. Prabhakara, K.S.; Kota, D.J.; Jones, G.H.; Srivastava, A.K.; Cox, C.S., Jr.; Olson, S.D. Teriflunomide Modulates Vascular Permeability and Microglial Activation after Experimental Traumatic Brain Injury. Mol. Ther. 2018, 26, 2152-2162. [CrossRef]

257. Pol, S.; Sveinsson, M.; Sudyn, M.; Babek, N.; Siebert, D.; Bertolino, N.; Modica, C.M.; Preda, M.; Schweser, F.; Zivadinov, R. Teriflunomide's Effect on Glia in Experimental Demyelinating Disease: A Neuroimaging and Histologic Study. J. Neuroimaging 2019, 29, 52-61. [CrossRef]

258. Wostradowski, T.; Prajeeth, C.K.; Gudi, V.; Kronenberg, J.; Witte, S.; Brieskorn, M.; Stangel, M. In vitro evaluation of physiologically relevant concentrations of teriflunomide on activation and proliferation of primary rodent microglia. J. Neuroinflammation 2016, 13, 250. [CrossRef]

259. Gottle, P.; Manousi, A.; Kremer, D.; Reiche, L.; Hartung, H.P.; Kury, P. Teriflunomide promotes oligodendroglial differentiation and myelination. J. Neuroinflammation 2018, 15, 76. [CrossRef]

260. Varrin-Doyer, M.; Pekarek, K.L.; Spencer, C.M.; Bernard, C.C.; Sobel, R.A.; Cree, B.A.; Schulze-Topphoff, U.; Zamvil, S.S. Treatment of spontaneous EAE by laquinimod reduces Tfh, B cell aggregates, and disease progression. Neurol. Neuroimmunol. Neuroinflamm. 2016, 3, e272. [CrossRef]

261. Wilmes, A.T.; Reinehr, S.; Kuhn, S.; Pedreiturria, X.; Petrikowski, L.; Faissner, S.; Ayzenberg, I.; Stute, G.; Gold, R.; Dick, H.B.; et al. Laquinimod protects the optic nerve and retina in an experimental autoimmune encephalomyelitis model. J. Neuroinflammation 2018, 15, 183. [CrossRef] [PubMed]

262. Kaye, J.; Piryatinsky, V.; Birnberg, T.; Hingaly, T.; Raymond, E.; Kashi, R.; Amit-Romach, E.; Caballero, I.S.; Towfic, F.; Ator, M.A.; et al. Laquinimod arrests experimental autoimmune encephalomyelitis by activating the aryl hydrocarbon receptor. Proc. Natl. Acad. Sci. USA 2016, 113, E6145-E6152. [CrossRef] [PubMed]

263. Mishra, M.K.; Wang, J.; Keough, M.B.; Fan, Y.; Silva, C.; Sloka, S.; Hayardeny, L.; Bruck, W.; Yong, V.W. Laquinimod reduces neuroaxonal injury through inhibiting microglial activation. Ann. Clin. Transl. Neurol. 2014, 1, 409-422. [CrossRef] [PubMed]

264. Nyamoya, S.; Steinle, J.; Chrzanowski, U.; Kaye, J.; Schmitz, C.; Beyer, C.; Kipp, M. Laquinimod Supports Remyelination in Non-Supportive Environments. Cells 2019, 8, 1363. [CrossRef]

265. Nedelcu, J.; Reinbach, C.; Riedler, P.; Brendel, M.; Rominger, A.; Kaye, J.; Behrangi, N.; Jiangshan, Z.; Schmitz, C.; Kipp, M. Laquinimod ameliorates secondary brain inflammation. Neurobiol. Dis. 2020, 134, 104675. [CrossRef]

266. Moore, S.; Khalaj, A.J.; Yoon, J.; Patel, R.; Hannsun, G.; Yoo, T.; Sasidhar, M.; Martinez-Torres, L.; Hayardeny, L.; Tiwari-Woodruff, S.K. Therapeutic laquinimod treatment decreases inflammation, initiates axon remyelination, and improves motor deficit in a mouse model of multiple sclerosis. Brain Behav. 2013, 3, 664-682. [CrossRef]

267. Kramann, N.; Menken, L.; Hayardeny, L.; Hanisch, U.K.; Bruck, W. Laquinimod prevents cuprizone-induced demyelination independent of Toll-like receptor signaling. Neurol. Neuroimmunol. Neuroinflamm. 2016, 3, e233. [CrossRef]

268. Bruck, W.; Pfortner, R.; Pham, T.; Zhang, J.; Hayardeny, L.; Piryatinsky, V.; Hanisch, U.K.; Regen, T.; van Rossum, D.; Brakelmann, L.; et al. Reduced astrocytic NF-kappaB activation by laquinimod protects from cuprizone-induced demyelination. Acta. Neuropathol. 2012, 124, 411-424. [CrossRef]

269. Ruffini, F.; Rossi, S.; Bergamaschi, A.; Brambilla, E.; Finardi, A.; Motta, C.; Studer, V.; Barbieri, F.; De Chiara, V.; Hayardeny, L.; et al. Laquinimod prevents inflammation-induced synaptic alterations occurring in experimental autoimmune encephalomyelitis. Mult. Scler. 2013, 19, 1084-1094. [CrossRef] 
270. Beckers, L.; Ory, D.; Geric, I.; Declercq, L.; Koole, M.; Kassiou, M.; Bormans, G.; Baes, M. Increased Expression of Translocator Protein (TSPO) Marks Pro-inflammatory Microglia but Does Not Predict Neurodegeneration. Mol. Imaging Biol. 2018, 20, 94-102. [CrossRef]

271. Katsumoto, A.; Miranda, A.S.; Butovsky, O.; Teixeira, A.L.; Ransohoff, R.M.; Lamb, B.T. Laquinimod attenuates inflammation by modulating macrophage functions in traumatic brain injury mouse model. J. Neuroinflammation 2018, 15, 26. [CrossRef] [PubMed]

272. Guo, Y.; Hong, W.; Wang, X.; Zhang, P.; Korner, H.; Tu, J.; Wei, W. MicroRNAs in Microglia: How do MicroRNAs Affect Activation, Inflammation, Polarization of Microglia and Mediate the Interaction Between Microglia and Glioma? Front Mol. Neurosci. 2019, 12, 125. [CrossRef] [PubMed]

273. Kelland, E.E.; Gilmore, W.; Hayardeny, L.; Weiner, L.P.; Lund, B.T. In vitro assessment of the direct effect of laquinimod on basic functions of human neural stem cells and oligodendrocyte progenitor cells. J. Neurol. Sci. 2014, 346, 66-74. [CrossRef]

274. Pittaluga, A. CCL5-Glutamate Cross-Talk in Astrocyte-Neuron Communication in Multiple Sclerosis. Front. Immunol. 2017, 8, 1079. [CrossRef] [PubMed]

275. Ellrichmann, G.; Blusch, A.; Fatoba, O.; Brunner, J.; Reick, C.; Hayardeny, L.; Hayden, M.; Sehr, D.; Winklhofer, K.F.; Saft, C.; et al. Laquinimod treatment in the R6/2 mouse model. Sci. Rep. 2017, 7, 4947. [CrossRef] [PubMed]

276. Ehrnhoefer, D.E.; Caron, N.S.; Deng, Y.; Qiu, X.; Tsang, M.; Hayden, M.R. Laquinimod decreases Bax expression and reduces caspase-6 activation in neurons. Exp. Neurol. 2016, 283, 121-128. [CrossRef] [PubMed]

277. Gil-Ad, I.; Amit, B.H.; Hayardeni, L.; Tarasenko, I.; Taler, M.; Gueta, R.U.; Weizman, A. Effects of the anti-multiple sclerosis immunomodulator laquinimod on anxiety and depression in rodent behavioral models. J. Mol. Neurosci. 2015, 55, 552-560. [CrossRef]

278. Stassart, R.M.; Helms, G.; Garea-Rodriguez, E.; Nessler, S.; Hayardeny, L.; Wegner, C.; Schlumbohm, C.; Fuchs, E.; Bruck, W. A New Targeted Model of Experimental Autoimmune Encephalomyelitis in the Common Marmoset. Brain Pathol. 2016, 26, 452-464. [CrossRef]

279. Lehotzky, A.; Lau, P.; Tokesi, N.; Muja, N.; Hudson, L.D.; Ovadi, J. Tubulin polymerization-promoting protein (TPPP/p25) is critical for oligodendrocyte differentiation. Glia 2010, 58, 157-168. [CrossRef]

280. Oh, J.; O'Connor, P.W. Established disease-modifying treatments in relapsing-remitting multiple sclerosis. Curr. Opin. Neurol. 2015, 28, 220-229. [CrossRef]

281. Rodi, M.; Dimisianos, N.; de Lastic, A.L.; Sakellaraki, P.; Deraos, G.; Matsoukas, J.; Papathanasopoulos, P.; Mouzaki, A. Regulatory Cell Populations in Relapsing-Remitting Multiple Sclerosis (RRMS) Patients: Effect of Disease Activity and Treatment Regimens. Int. J. Mol. Sci. 2016, 17, 1398. [CrossRef] [PubMed]

282. Banisadr, G.; Schwartz, S.R.; Podojil, J.R.; Piccinini, L.A.; Lanker, S.; Miller, S.D.; Miller, R.J. Integrin/Chemokine receptor interactions in the pathogenesis of experimental autoimmune encephalomyelitis. J. Neuroimmune. Pharmacol. 2014, 9, 438-445. [CrossRef] [PubMed]

283. Escribano, B.M.; Medina-Fernandez, F.J.; Aguilar-Luque, M.; Aguera, E.; Feijoo, M.; Garcia-Maceira, F.I.; Lillo, R.; Vieyra-Reyes, P.; Giraldo, A.I.; Luque, E.; et al. Lipopolysaccharide Binding Protein and Oxidative Stress in a Multiple Sclerosis Model. Neurotherapeutics 2017, 14, 199-211. [CrossRef] [PubMed]

284. Manocha, G.; Ghatak, A.; Puig, K.; Combs, C. Anti-alpha4beta1 Integrin Antibodies Attenuated Brain Inflammatory Changes in a Mouse Model of Alzheimer's Disease. Curr. Alzheimer Res. 2018, 15, 1123-1135. [CrossRef]

285. Mindur, J.E.; Ito, N.; Dhib-Jalbut, S.; Ito, K. Early treatment with anti-VLA-4 mAb can prevent the infiltration and/or development of pathogenic CD11b+CD4+ T cells in the CNS during progressive EAE. PLoS ONE 2014, 9, e99068. [CrossRef]

286. Politis, M.; Giannetti, P.; Niccolini, F.; Su, P.; Turkheimer, F.; Waldman, A.; Reynolds, R.; Nicholas, R.; Piccini, P. Decreased Microglial Activation Precedes Stabilization of Disability in Multiple Sclerosis Patients Treated with Natalizumab (S21.004). Neurology 2013, 80, S21.004.

287. Sucksdorff, M.; Tuisku, J.; Matilainen, M.; Vuorimaa, A.; Smith, S.; Keitila, J.; Rokka, J.; Parkkola, R.; Nylund, M.; Rinne, J.; et al. Natalizumab treatment reduces microglial activation in the white matter of the MS brain. Neurol. Neuroimmunol. Neuroinflamm. 2019, 6, e574. [CrossRef] 
288. Ohrfelt, A.; Axelsson, M.; Malmestrom, C.; Novakova, L.; Heslegrave, A.; Blennow, K.; Lycke, J.; Zetterberg, H. Soluble TREM-2 in cerebrospinal fluid from patients with multiple sclerosis treated with natalizumab or mitoxantrone. Mult. Scler. 2016, 22, 1587-1595. [CrossRef]

289. Olsson, B.; Malmestrom, C.; Basun, H.; Annas, P.; Hoglund, K.; Lannfelt, L.; Andreasen, N.; Zetterberg, H.; Blennow, K. Extreme stability of chitotriosidase in cerebrospinal fluid makes it a suitable marker for microglial activation in clinical trials. J. Alzheimers Dis. 2012, 32, 273-276. [CrossRef]

290. Falcon, C.; Monte-Rubio, G.C.; Grau-Rivera, O.; Suarez-Calvet, M.; Sanchez-Valle, R.; Rami, L.; Bosch, B.; Haass, C.; Gispert, J.D.; Molinuevo, J.L. CSF glial biomarkers YKL40 and sTREM2 are associated with longitudinal volume and diffusivity changes in cognitively unimpaired individuals. Neuroimage Clin. 2019, 23, 101801. [CrossRef]

291. Martinez-Merino, L.; Iridoy, M.; Galbete, A.; Roldan, M.; Rivero, A.; Acha, B.; Irun, P.; Canosa, C.; Pocovi, M.; Mendioroz, M.; et al. Evaluation of Chitotriosidase and CC-Chemokine Ligand 18 as Biomarkers of Microglia Activation in Amyotrophic Lateral Sclerosis. Neurodegener Dis. 2018, 18, 208-215. [CrossRef] [PubMed]

292. Hailer, N.P.; Bechmann, I.; Heizmann, S.; Nitsch, R. Adhesion molecule expression on phagocytic microglial cells following anterograde degeneration of perforant path axons. Hippocampus 1997, 7, 341-349. [CrossRef]

293. Lee, S.; Jha, M.K.; Suk, K. Lipocalin-2 in the Inflammatory Activation of Brain Astrocytes. Crit. Rev. Immunol. 2015, 35, 77-84. [CrossRef] [PubMed]

294. Chun, B.Y.; Kim, J.H.; Nam, Y.; Huh, M.I.; Han, S.; Suk, K. Pathological Involvement of Astrocyte-Derived Lipocalin-2 in the Demyelinating Optic Neuritis. Investig. Ophthalmol. Vis. Sci. 2015, 56, 3691-3698. [CrossRef] [PubMed]

295. Marques, F.; Mesquita, S.D.; Sousa, J.C.; Coppola, G.; Gao, F.; Geschwind, D.H.; Columba-Cabezas, S.; Aloisi, F.; Degn, M.; Cerqueira, J.J.; et al. Lipocalin 2 is present in the EAE brain and is modulated by natalizumab. Front Cell Neurosci. 2012, 6, 33. [CrossRef] [PubMed]

296. Al Nimer, F.; Elliott, C.; Bergman, J.; Khademi, M.; Dring, A.M.; Aeinehband, S.; Bergenheim, T.; Romme Christensen, J.; Sellebjerg, F.; Svenningsson, A.; et al. Lipocalin-2 is increased in progressive multiple sclerosis and inhibits remyelination. Neurol. Neuroimmunol. Neuroinflamm. 2016, 3, e191. [CrossRef]

297. Hu, Y.; Turner, M.J.; Shields, J.; Gale, M.S.; Hutto, E.; Roberts, B.L.; Siders, W.M.; Kaplan, J.M. Investigation of the mechanism of action of alemtuzumab in a human CD52 transgenic mouse model. Immunology 2009, 128, 260-270. [CrossRef]

298. Rao, S.P.; Sancho, J.; Campos-Rivera, J.; Boutin, P.M.; Severy, P.B.; Weeden, T.; Shankara, S.; Roberts, B.L.; Kaplan, J.M. Human peripheral blood mononuclear cells exhibit heterogeneous CD52 expression levels and show differential sensitivity to alemtuzumab mediated cytolysis. PLoS ONE 2012, 7, e39416. [CrossRef] [PubMed]

299. Watanabe, T.; Masuyama, J.; Sohma, Y.; Inazawa, H.; Horie, K.; Kojima, K.; Uemura, Y.; Aoki, Y.; Kaga, S.; Minota, S.; et al. CD52 is a novel costimulatory molecule for induction of CD4+ regulatory T cells. Clin. Immunol. 2006, 120, 247-259. [CrossRef]

300. Chatterjee, D.; Addya, S.; Khan, R.S.; Kenyon, L.C.; Choe, A.; Cohrs, R.J.; Shindler, K.S.; Sarma, J.D. Mouse hepatitis virus infection upregulates genes involved in innate immune responses. PLoS ONE 2014, 9, e111351. [CrossRef]

301. Ellwardt, E.; Vogelaar, C.F.; Maldet, C.; Schmaul, S.; Bittner, S.; Luchtman, D. Targeting CD52 does not affect murine neuron and microglia function. Eur. J. Pharmacol. 2020, 871, 172923. [CrossRef] [PubMed]

302. Knier, B.; Hemmer, B.; Korn, T. Novel monoclonal antibodies for therapy of multiple sclerosis. Expert Opin Biol Ther 2014, 14, 503-513. [CrossRef] [PubMed]

303. Milo, R. Therapeutic strategies targeting B-cells in multiple sclerosis. Autoimmun. Rev. 2016, 15, 714-718. [CrossRef] [PubMed]

304. Moreno Torres, I.; Garcia-Merino, A. Anti-CD20 monoclonal antibodies in multiple sclerosis. Expert. Rev. Neurother. 2017, 17, 359-371. [CrossRef]

305. Hausler, D.; Hausser-Kinzel, S.; Feldmann, L.; Torke, S.; Lepennetier, G.; Bernard, C.C.A.; Zamvil, S.S.; Bruck, W.; Lehmann-Horn, K.; Weber, M.S. Functional characterization of reappearing B cells after anti-CD20 treatment of CNS autoimmune disease. Proc. Natl. Acad. Sci. USA 2018, 115, 9773-9778. [CrossRef] 
306. Szepesi, Z.; Manouchehrian, O.; Bachiller, S.; Deierborg, T. Bidirectional Microglia-Neuron Communication in Health and Disease. Front Cell Neurosci. 2018, 12, 323. [CrossRef]

307. Domingues, H.S.; Portugal, C.C.; Socodato, R.; Relvas, J.B. Oligodendrocyte, Astrocyte, and Microglia Crosstalk in Myelin Development, Damage, and Repair. Front Cell Dev. Biol. 2016, 4, 71. [CrossRef]

308. Przanowski, P.; Dabrowski, M.; Ellert-Miklaszewska, A.; Kloss, M.; Mieczkowski, J.; Kaza, B.; Ronowicz, A.; Hu, F.; Piotrowski, A.; Kettenmann, H.; et al. The signal transducers Stat1 and Stat3 and their novel target Jmjd3 drive the expression of inflammatory genes in microglia. J. Mol. Med. (Berl) 2014, 92, 239-254. [CrossRef]

309. Liu, T.; Zhang, L.; Joo, D.; Sun, S.C. NF-kappaB signaling in inflammation. Signal Transduct Target Ther. 2017, 2. [CrossRef]

310. Mussbacher, M.; Salzmann, M.; Brostjan, C.; Hoesel, B.; Schoergenhofer, C.; Datler, H.; Hohensinner, P.; Basilio, J.; Petzelbauer, P.; Assinger, A.; et al. Cell Type-Specific Roles of NF-kappaB Linking Inflammation and Thrombosis. Front Immunol. 2019, 10, 85. [CrossRef]

311. Kramer, O.H.; Baus, D.; Knauer, S.K.; Stein, S.; Jager, E.; Stauber, R.H.; Grez, M.; Pfitzner, E.; Heinzel, T. Acetylation of Stat1 modulates NF-kappaB activity. Genes Dev. 2006, 20, 473-485. [CrossRef] [PubMed]

312. Yao, L.; Kan, E.M.; Lu, J.; Hao, A.; Dheen, S.T.; Kaur, C.; Ling, E.A. Toll-like receptor 4 mediates microglial activation and production of inflammatory mediators in neonatal rat brain following hypoxia: Role of TLR4 in hypoxic microglia. J. Neuroinflammation 2013, 10, 23. [CrossRef] [PubMed]

313. Song, M.; Jin, J.; Lim, J.E.; Kou, J.; Pattanayak, A.; Rehman, J.A.; Kim, H.D.; Tahara, K.; Lalonde, R.; Fukuchi, K. TLR4 mutation reduces microglial activation, increases Abeta deposits and exacerbates cognitive deficits in a mouse model of Alzheimer's disease. J. Neuroinflammation 2011, 8, 92. [CrossRef] [PubMed]

314. Akhmetzyanova, E.; Kletenkov, K.; Mukhamedshina, Y.; Rizvanov, A. Different Approaches to Modulation of Microglia Phenotypes After Spinal Cord Injury. Front Syst. Neurosci. 2019, 13, 37. [CrossRef]

315. Ceyzeriat, K.; Ben Haim, L.; Denizot, A.; Pommier, D.; Matos, M.; Guillemaud, O.; Palomares, M.A.; Abjean, L.; Petit, F.; Gipchtein, P.; et al. Modulation of astrocyte reactivity improves functional deficits in mouse models of Alzheimer's disease. Acta Neuropathol. Commun. 2018, 6, 104. [CrossRef]

316. Nutma, E.; van Gent, D.; Amor, S.; Peferoen, L.A.N. Astrocyte and Oligodendrocyte Cross-Talk in the Central Nervous System. Cells 2020, 9, 600. [CrossRef]

317. Allen, N.J.; Eroglu, C. Cell Biology of Astrocyte-Synapse Interactions. Neuron 2017, 96, 697-708. [CrossRef]

318. Peferoen, L.; Kipp, M.; van der Valk, P.; van Noort, J.M.; Amor, S. Oligodendrocyte-microglia cross-talk in the central nervous system. Immunology 2014, 141, 302-313. [CrossRef]

319. Oksanen, M.; Lehtonen, S.; Jaronen, M.; Goldsteins, G.; Hamalainen, R.H.; Koistinaho, J. Astrocyte alterations in neurodegenerative pathologies and their modeling in human induced pluripotent stem cell platforms. Cell Mol. Life Sci. 2019, 76, 2739-2760. [CrossRef]

320. Jha, M.K.; Jo, M.; Kim, J.H.; Suk, K. Microglia-Astrocyte Crosstalk: An Intimate Molecular Conversation. Neuroscientist 2019, 25, 227-240. [CrossRef]

321. Liddelow, S.A.; Guttenplan, K.A.; Clarke, L.E.; Bennett, F.C.; Bohlen, C.J.; Schirmer, L.; Bennett, M.L.; Munch, A.E.; Chung, W.S.; Peterson, T.C.; et al. Neurotoxic reactive astrocytes are induced by activated microglia. Nature 2017, 541, 481-487. [CrossRef] [PubMed]

322. Rothhammer, V.; Borucki, D.M.; Tjon, E.C.; Takenaka, M.C.; Chao, C.C.; Ardura-Fabregat, A.; de Lima, K.A.; Gutierrez-Vazquez, C.; Hewson, P.; Staszewski, O.; et al. Microglial control of astrocytes in response to microbial metabolites. Nature 2018, 557, 724-728. [CrossRef] [PubMed]

323. Haruwaka, K.; Ikegami, A.; Tachibana, Y.; Ohno, N.; Konishi, H.; Hashimoto, A.; Matsumoto, M.; Kato, D.; Ono, R.; Kiyama, H.; et al. Dual microglia effects on blood brain barrier permeability induced by systemic inflammation. Nat. Commun. 2019, 10, 5816. [CrossRef] [PubMed]

324. Friedman, B.A.; Srinivasan, K.; Ayalon, G.; Meilandt, W.J.; Lin, H.; Huntley, M.A.; Cao, Y.; Lee, S.H.; Haddick, P.C.G.; Ngu, H.; et al. Diverse Brain Myeloid Expression Profiles Reveal Distinct Microglial Activation States and Aspects of Alzheimer's Disease Not Evident in Mouse Models. Cell Rep. 2018, 22, 832-847. [CrossRef] 
325. van der Poel, M.; Ulas, T.; Mizee, M.R.; Hsiao, C.C.; Miedema, S.S.M.; Adelia; Schuurman, K.G.; Helder, B.; Tas, S.W.; Schultze, J.L.; et al. Transcriptional profiling of human microglia reveals grey-white matter heterogeneity and multiple sclerosis-associated changes. Nat. Commun. 2019, 10, 1139. [CrossRef]

326. Lee, J.; Hamanaka, G.; Lo, E.H.; Arai, K. Heterogeneity of microglia and their differential roles in white matter pathology. CNS Neurosci. Ther. 2019, 25, 1290-1298. [CrossRef]

(C) 2020 by the authors. Licensee MDPI, Basel, Switzerland. This article is an open access article distributed under the terms and conditions of the Creative Commons Attribution (CC BY) license (http://creativecommons.org/licenses/by/4.0/). 